\title{
Fetichismo da mercadoria e inconsciente: contribuições marxianas e psicanalíticas para uma teoria da ideologia \\ (versão original)
}

\begin{abstract}
Dissertação apresentada ao Instituto de Psicologia da Universidade de São Paulo para obtenção do grau de Mestre em Psicologia.

Área de concentração: Psicologia Escolar e do Desenvolvimento Humano.

Orientador: Prof. Dr. Paulo Cesar Endo
\end{abstract}

São Paulo 
AUTORIZO A REPRODUÇÃO E DIVULGAÇÃO TOTAL OU PARCIAL DESTE TRABALHO, POR QUALQUER MEIO CONVENCIONAL OU ELETRÔNICO, PARA FINS DE ESTUDO E PESQUISA, DESDE QUE CITADA A FONTE.

Catalogação na publicação Biblioteca Dante Moreira Leite Instituto de Psicologia da Universidade de São Paulo

Dezan, Lúcia Cristina.

Fetichismo da mercadoria e inconsciente: contribuições marxianas e psicanalíticas para uma teoria da ideologia / Lúcia Cristina Dezan; orientador Paulo César Endo. -- São Paulo, 2013.

$106 \mathrm{f}$.

Dissertação (Mestrado - Programa de Pós-Graduação em Psicologia. Área de Concentração: Psicologia Escolar e do Desenvolvimento Humano) - Instituto de Psicologia da Universidade de São Paulo.

1. Fetichismo da mercadoria 2. Fantasia inconsciente 3. Separação 4. Marx, Karl Heinrich, 5.5.1818-14.3.1883 5. Lacan, Jacques, 1901-1981 6. Žižek, Slavoj, 21.3.1949- I. Título. 
Nome: DEZAN, Lúcia Cristina

Título: Fetichismo da mercadoria e inconsciente: contribuições marxianas e psicanalíticas para uma teoria da ideologia

Dissertação apresentada ao Instituto de Psicologia da Universidade de São Paulo para obtenção do grau de Mestre em Psicologia.

Aprovada em: / 2013

\section{Banca Examinadora}

Prof. Dr. Paulo Cesar Endo

(Universidade de São Paulo)

Prof. Dr. Paulo Argimiro da Silveira (Universidade de São Paulo)

Prof. Dr. Christian Ingo Lenz Dunker (Universidade de São Paulo)

Prof. Dr. Ricardo Musse (Suplente) (Universidade de São Paulo)

Profa. Dra. Miriam Debieux Rosa (Suplente) (Universidade de São Paulo)

Prof. Dr. Paulo Albertini (Suplente) (Universidade de São Paulo) 
Ao meu pai, Antonio Celso Dezan, pelo "Ponto de Luz". 


\section{AGRADECIMENTOS}

A Márcia, amada irmã, meu ponto de apoio na corda bamba da vida.

Mãe, ainda tentando encontrar palavras...

A Paulo Endo, meu orientador, que apostou veementemente em meu mestrado e em meu tema desde o início; que apostou em mim.

Ao grupo de orientação, em especial, Gabi Costardi, Cris Izumi, Luiz Moreno, Luiz Henrique Conceição e Van Lopes, pela companhia na travessia deste percurso, que se tornou menos solitária, e pela amizade que nasceu.

Aos meus analisantes que me permitem praticar a psicanálise e sustentar 0 que escrevo.

A Paulo Argimiro da Silveira pelo diálogo incansável ao longo deste estudo e pela companhia generosa nessa caminhada. A você, a minha gratidão e admiração pelo trabalho de fazer Marx e a psicanálise dialogarem.

A Christian Dunker pelas considerações extremamente cuidadosas no exame de qualificação, um respiro para eu seguir adiante.

A Lilian Clementoni, pelo "Bom Encontro" da minha vida, pela profunda parceria na amizade e neste trabalho e pelo infindável debate entre marxismo e psicanálise, que se iniciou na graduação e segue nas nossas vidas, despertando dores e alegrias agudas.

A Tatisa Gica, pela amizade, pela presença forte e doce e pelos diálogos intermináveis sobre psicanálise e clínica psicanalítica, os quais ajudaram a sustentar esta pesquisa.

A Sirlene Botelho, pelo amor há mais de vinte anos, pelos momentos de tomada de fôlego no interior, quando pude me desligar dos estudos e sair em sua companhia para um passeio de bike, um café e um bom papo.

A Eveline Hauck, pela intimidade da amizade que construímos, pelas sessões de cinema, pelos inúmeros debates políticos e filosóficos e pela tradução do resumo para o inglês.

A Renata Oliveira Figueiredo pela presença incansável na amizade que se aprofunda a cada dia, por ensinar-me muito sobre exercer a coragem e pela parceria radical nas lutas diárias no Caps.

A Adriana Gabrieli pela amizade tumultuada que há entre quem convive com intimidade e pelas batalhas travadas no Caps. 
A Isaac Soares Bastos pela amizade que cresce a cada dia e por ter me ajudado a não perder a ternura no trabalho no Caps.

A Dedê Paiva, que vem se tornando uma amiga, pelas conversas que compartilhamos e pelos momentos de diversão, respiros que me ajudaram a prosseguir na pesquisa.

A Teresinha Baiana pelo amor maternal e pelo início em Marx.

A Omar Ardans pela amizade e pelos primeiros debates polêmicos entre psicologia social e psicanálise.

A Maria Carolina Azevedo e a Cristiano Rezende por terem plantado a semente da paixão pela filosofia.

A Maria de Jesus Assis, com quem aprendi, pela primeira vez, que é possível ocupar um lugar institucional de poder de forma emancipatória, sem oprimir.

A Conrado Ramos, com quem tanto venho aprendendo sobre psicanálise e clínica psicanalítica.

A Luigi Barrichello por compartilhar sua excelente tese, pelo diálogo sobre Žižek e pela camaradagem dos livros emprestados.

A Gui Silva pela ajuda carinhosa com a impressão deste trabalho.

A Luiz Fukushiro pela excelente revisão desta dissertação e pela disponibilidade para trabalharmos juntos.

Ao Núcleo de Educação Popular Treze de Maio por boa parte da minha formação em Marx.

Ao Movimento Estudantil, decisivo na minha formação. 


\section{RESUMO}

DEZAN, Lúcia Cristina. Fetichismo da mercadoria e inconsciente: Contribuições marxianas e psicanalíticas para uma teoria da ideologia. 2013. $106 \mathrm{f}$. Dissertação (Mestrado) - Instituto de Psicologia, Universidade de São Paulo, São Paulo, 2013.

Este trabalho tem por objetivo construir um diálogo teórico entre a alienação do fetichismo da mercadoria, em Marx, e algumas categorias da psicanálise. A noção marxista clássica de ideologia, concebida como o desconhecimento e a distorção da consciência necessariamente produzidos pelas condições efetivas da realidade social, é criticada pelo filósofo esloveno Slavoj Žižek, ao trazer para o campo da ideologia a noção psicanalítica de fantasia. Entretanto, realizamos uma primeira problematização dessa elaboração do filósofo por dirigir a sua crítica a essa noção de ideologia, remetendo-a ao fetichismo da mercadoria. Mostramos que esse conceito de ideologia a que a sua crítica se dirige se adéqua justamente à noção de ideologia desenvolvida por Marx e Engels n'A ideologia alemã, e não ao fetichismo da mercadoria, visto que o fetichismo comporta uma noção mais complexa que não se resume a um mero desconhecimento da realidade e a uma distorção socialmente necessária da consciência. Retornamos a $O$ capital de Marx para mostrar as imbricações da fantasia no fetichismo da mercadoria e para mostrar que a sujeição que atinge os sujeitos sob a alienação fetichista é da ordem do inconsciente. No contexto da relação entre fetichismo da mercadoria e inconsciente, problematizamos também aquilo que denominamos uma "generalização" a que Žižek incorre, ao defender a tese de que a alienação fetichista teria se deslocado genericamente do saber para o fazer humano. Dessa forma, concluímos que a formulação marxiana, "Não o sabem, mas o fazem", continua atual e exercendo o seu poder ideológico, dependendo das condições sócio-simbólicas em que os sujeitos se inserem e são inseridos. Para compreender o sentido da noção de fantasia no campo da ideologia, empreendemos uma breve apresentação da noção freudiana da fantasia até uma compreensão lacaniana, em sua dimensão de gozo e de objeto a, elaborada por Žižek. O filósofo realiza uma distinção entre sintoma e fantasia para dizer que a ideologia não se estrutura na forma do primeiro, mas sim da segunda, em que a fantasia ideológica, em sua dimensão real, estrutura a realidade social. Na direção da pista deixada por Žižek, seguimos rumo às operações lacanianas de alienação e separação para pensar possibilidades do sujeito fazer frente à ideologia. Apresentamos, então, um estudo dessas operações em Lacan, e elaboramos, por nossa própria conta e risco, uma articulação delas com o fetichismo da mercadoria, tentando mostrar as determinações mútuas entre fetichismo e inconsciente. Da mesma forma que a fantasia ideológica e a operação da alienação operam um fechamento imaginário da abertura possibilitada pela separação, essa operação permite uma abertura desejante entre sujeito e Outro, lugar de onde se poderia partir para uma crítica possível à ideologia.

Palavras-chave: fetichismo da mercadoria, fantasia inconsciente, separação, Karl Heinrich Marx, Jacques Lacan, Slavoj Žižek. 


\section{ABSTRACT}

DEZAN, Lúcia Cristina. Commodity fetishism and unconscious: Marxian and Psychoanalytic contributions to a theory of ideology. 2013. 106 p. Dissertation (Master) - Institute of Psychology, São Paulo University, São Paulo, 2013.

This paper aims to build a theoretical dialogue amongst the alienation of commodity fetishism in Marx, and some categories of psychoanalysis. The classical Marxist notion of ideology, conceived as the ignorance and the distortion of consciousness necessarily produced by the actual conditions of social reality, is criticized by the Slovenian philosopher Slavoj Žižek, in bringing to the field of ideology the psychoanalytic notion of fantasy. However, we perform an initial questioning of his elaboration, for he addresses his critique to this notion of ideology, reporting it to the commodity fetishism. We show that this concept of ideology that his criticism is addressed precisely fits in the notion of ideology developed by Marx and Engels, in The German Ideology, and not in the commodity fetishism, since the fetishism involves a more complex notion that is not summed to a mere ignorance of reality and to a socially necessary distortion of conscious. We return to Marx's Capital to show the imbrications of fantasy in commodity fetishism and to show that the subjection, which reaches the subjects under the fetishist alienation is of the order of the unconscious. In the context of the relationship between commodity fetishism and unconscious, we also problematize what we call a "generalization" that Žižek incurs in defending the thesis that fetishist alienation would have generically shifted from the human knowing to the human making. Thus, we conclude that the Marxian formulation, "We are not aware of this, nevertheless we do it", is still present and exerting its ideological power, depending on the socio-symbolic conditions in which the subjects insert themselves and are inserted. To understand the meaning of the notion of fantasy in the field of ideology, we undertake a brief presentation of the Freudian notion of fantasy to a Lacanian understanding, in its dimension of enjoyment and the object little-a, elaborated by Žižek. The philosopher makes a distinction between symptom and fantasy to say that ideology is structured not in the form of the former, but of the latter, in which the ideological fantasy, in its real dimension, structures the social reality. Towards the clue left by Žižek, we turn to the Lacanian operations of alienation and separation to think of possibilities to the subject to cope with ideology. Then we present a study of these operations in Lacan, and prepare at our own risk, an articulation of these psychic operations with commodity fetishism, trying to show the mutual determinations between fetishism and unconscious. Just as the ideological fantasy and the operation of alienation carry out an imaginary closure of the opening made possible by the separation, this operation allows a desiring gap between subject and Other, a place from which one could depart for a possible critique of ideology.

Keywords: commodity fetishism, unconscious fantasy, separation, Karl Heinrich Marx, Jacques Lacan, Slavoj Žižek. 


\section{SUMÁRIO}

CONSIDERAÇÕES INICIAIS 10

\section{A IDEOLOGIA COMO ALIENAÇÃO E O SINTOMA 14}

1.1 A ideologia como inversão socialmente necessária da consciência 14

1.2 Alienação e sintoma 23

1.3 Sintoma e recalque originário: do significante ao gozo 30

2 DA FANTASIA FREUDIANA AO REAL DA FANTASIA 39

2.1 A noção freudiana de fantasia 39

2.2 Crítica à noção de realidade como "realismo ingênuo"

45

2.3 Para além do sintoma: a fantasia 47

2.4 Da fantasia ao seu real 52

3 O FETICHISMO DA MERCADORIA E A SUA RELAÇÃO COM O INCONSCIENTE E A FANTASIA 57

3.1 A forma mercadoria e as suas determinações 57

3.2 Fetichismo: um lugar (no pensar) para um não saber? 62

3.3 Da forma simples de valor à forma dinheiro: o recalcado do dinheiro ou o enigmático da forma 66

3.3.1 Forma de valor total ou desdobrada 72

3.3.2 Forma geral de valor 73

3.3.3 Forma dinheiro 74

3.4 Fetichismo e inconsciente 75

4 ALIENAÇÃO, SEPARAÇÃO E IDEOLOGIA 80

4.1 Alienação 81

4.2 Separação (em oposição à alienação) 84

4.3 Separação, alienação e objeto a 88

4.4 Alienação, separação e fetichismo 95

CONSIDERAÇÕES FINAIS 99

REFERÊNCIAS BIBLIOGRÁFICAS 103 


\section{CONSIDERAÇÕES INICIAIS}

Esta pesquisa de mestrado possui uma vocação teórica, portanto o método utilizado foi a leitura e a análise dos textos selecionados. Nosso objetivo era, inicialmente, fazer um estudo da ideologia no pensamento do filósofo Slavoj Žižek, por extrair da teoria psicanalítica contribuições para pensar a ideologia e também pelo seu estilo de articulação entre o marxismo e a psicanálise. Porém, no decorrer da pesquisa, o nosso objetivo foi se transformando e o nosso interesse passou a dirigir-se com mais força para os textos de Marx, Freud e Lacan, de forma que Žižek se tornou relativizado. Este trabalho, portanto, deixou de ser um estudo sobre a ideologia no pensamento desse autor e passou a eleger algumas de suas controversas teses sobre a ideologia como ponto de contato entre Marx e a psicanálise. Essas teses foram debatidas e problematizadas em alguns pontos que nos permitiram fazer aquilo que almejávamos desde o início: dialogar Marx com a psicanálise, principalmente a lacaniana. Mesmo relativizado, Žižek foi indispensável, ao indicar-nos as pontes para criar o diálogo entre alguns conceitos fundamentais do marxismo e da psicanálise, como ideologia, alienação, fantasia inconsciente, gozo, fetichismo, entre outros, com o objetivo de tecer algumas contribuições psicanalíticas e marxianas para uma teoria da ideologia.

O momento do exame de qualificação foi decisivo para essa mudança, apesar dessa percepção ter ocorrido apenas um tempo depois. A indagação feita pela banca sobre se as questões que Žižek discute já não estariam presentes, ainda que de maneira latente, nos textos de Marx e Lacan e, em sequência, a pontuação de que a clareza dessa indagação apenas era possível após o filósofo esloveno ter feito esse diálogo direto entre marxismo e psicanálise lacaniana, tiveram o efeito de uma interpretação, o que modificou os rumos deste trabalho. Os efeitos foram percebidos ao longo desse último ano de estudo, na medida em que cada vez mais retornávamos às leituras dos textos selecionados de Marx e Lacan. Assumir certo distanciamento do pensamento de Žižek foi necessário para que pudéssemos levantar indagações importantes sobre algumas de suas controversas teses. Esse distanciamento crítico foi possível devido às discussões ocorridas no grupo de orientação e, principalmente, às discussões com o orientador desta pesquisa, que trouxe contribuições decisivas para que pudéssemos problematizar as leituras e os estudos realizados. 
Procuramos desenvolver alguns alinhavos teóricos que não localizamos explicitamente em Žižek, ao menos do jeito esperado, e outros que localizamos e problematizamos a partir do retorno aos textos de Marx e Lacan. Elegemos, então, as seguintes teses sobre a ideologia elaboradas por Žižek: 1.) A ideologia concebida como uma construção da 'fantasia inconsciente', em seu registro 'real', que estrutura a realidade social; 2.) A mudança da incidência da ilusão do 'fetichismo da mercadoria' marxiano do âmbito do 'saber' para o 'fazer' humano, ou seja, o deslocamento do "Não o sabem, mas o fazem" para "Eles não sabem o que fazem" e; 3.) A noção de 'travessia da fantasia' ideológica a partir da identificação com o sinthoma.

A primeira tese nos lançou para um terreno conhecido da psicanálise, a fantasia, por isso, no segundo capítulo, apresentamos brevemente a descoberta freudiana da força de realidade da fantasia, a qual Freud denominou de 'realidade psíquica'. Seguimos da noção freudiana de fantasia para a sua dimensão real até alcançarmos a tese de Žižek sobre a ideologia como fantasia inconsciente que estrutura a realidade social. Ou seja, a ideologia não estaria estruturada na forma de um sintoma, mas na forma de uma fantasia. Percorremos, então, ainda nesse segundo capítulo, o texto de Jacques-Alain Miller do qual o filósofo esloveno obteve essa distinção entre sintoma e fantasia para elaborar uma de suas teses sobre a ideologia.

Essa distinção nos levou à construção do primeiro capítulo, em que realizamos um estudo da noção de ideologia, elaborada por Marx e Engels, na primeira parte d'A ideologia alemã. Buscamos estudar essa obra, pois pensamos que nela se localiza a noção de ideologia estruturada na forma do sintoma, com a ressalva da concepção de sintoma restrita a sua dimensão simbólica, significante. E assim nasceu outra problematização do texto de Žižek, devido ao fato de que, quando dirige a sua crítica à ideologia concebida como o desconhecimento e a inversão da consciência pela realidade, ele localiza essa noção de ideologia no fetichismo da mercadoria d'O capital. Refutamos essa afirmação, na medida em que fomos confirmando a nossa hipótese de que o fetichismo da mercadoria não constituía um mero desconhecimento ou uma inversão da consciência, mas abarcaria uma noção mais complexa.

Aliás, o terceiro capítulo resultou de uma questão que nos moveu profundamente no decorrer deste trabalho, nascida a partir de inúmeras leituras do 
primeiro capítulo d'O capital, e assim se condensava: seria a sujeição a que os sujeitos estão sob o fetichismo da mercadoria da ordem do inconsciente? Conseguimos, nesse capítulo, realizar alguns desdobramentos dessa hipótese a partir da problematização da tese de Žižek de que o fetichismo da mercadoria teria sofrido uma mudança em sua incidência do saber para o fazer humano. Essa nossa problematização foi se consolidando com o estudo sobre a gênese da 'forma dinheiro' em Marx, desde o seu nascedouro na 'forma simples de valor' até completar o seu movimento lógico e histórico na forma enigmática do dinheiro. Nesse sentido, tentamos mostrar as metamorfoses que levam a forma dinheiro a alcançar o estatuto de um fetiche, em que a fantasia paira sobre esse objeto, o qual passa a adquirir poderes mágicos e sobrenaturais sobre os sujeitos. Essa nossa crítica partiu da indagação inquietante sobre a maneira categórica e generalizada com que Žižek afirma que "Eles não sabem o que fazem" (ŽlŽEK, 1992), com o significado de que o 'não saber' dos sujeitos estaria localizado em sua ação, naquilo que 'fazem'. A questão acabou sendo reformulada da seguinte maneira: não haveria nos sujeitos, sob o capitalismo, sujeitados ao fetichismo da mercadoria, algum espaço para um lugar de 'não saber' no âmbito de seu próprio pensamento? Ou seja, se não haveria algum índice de ignorância nos sujeitos sob a fantasmática inconsciente da forma mercadoria não apenas no âmbito do que fazem, mas também daquilo que pensam. Diante dessa questão, retornamos ao texto de Marx e construímos argumentos que nos permitiram fazer algumas afirmações acerca da atualidade da força ideológica do fetichismo da mercadoria sobre os sujeitos, ainda que essa alienação fetichista, do "Não o sabem, mas o fazem", também não os atinja de forma generalizada.

No quarto capítulo, apresentamos um estudo sobre as operações lacanianas de causação do sujeito, de alienação e de separação e tentamos mostrar como essas operações psíquicas podem se articular com o fetichismo da mercadoria. Essas operações ora possibilitariam um fechamento imaginário no sujeito sob a alienação fetichista, produzido pela operação de alienação, ora operariam uma abertura psíquica, possibilitada pela separação, na medida em que essa operação produz uma abertura entre o sujeito e o Outro. E não poderia essa abertura, que faz do sujeito desejante, considerando, necessariamente, o inconsciente que o determina, ser o ponto de partida de uma crítica à ideologia? 
Ainda nesse capítulo, expusemos o sentido que a fantasia, em seu registro lacaniano do real, acarreta para a noção que Žižek apresenta da ideologia, a saber, a ideologia como uma fantasia social que sutura os efeitos do real, de qual extraímos mais uma questão: se o fechamento imaginário produzido pela fantasia social não coincidiria com o fetichismo da mercadoria, na medida em que esse, ao oferecer os objetos do mundo sob a forma mercadoria como objetos do desejo, serviria justamente para também suturar a falta constitutiva do sujeito que o torna sujeito desejante? Nesse sentido, fez-se fundamental a noção de objeto a para a crítica da ideologia, já que, conforme nos ensinou Lacan, constitui o objeto causa do desejo e não um suposto objeto do desejo, o qual fantasiosamente preencheria adequadamente a falta no sujeito. $O$ objeto $a$, efeito da operação de separação, entra na lacuna entre sujeito e Outro, possibilitando manter uma abertura desejante, na qual insistimos poder constituir um lugar propício de crítica à ideologia. 


\title{
1 A IDEOLOGIA COMO ALIENAÇÃO E O SINTOMA
}

— Este nosso rapazinho tem a vista curta. Espera aí, Miguilim...

E o senhor tirava os óculos e punha-os em Miguilim, com todo o jeito.

— Olha, agora!

Miguilim olhou. Nem não podia acreditar! Tudo era uma claridade, tudo novo e lindo e diferente, as coisas, as árvores, as caras das pessoas. Via os grãozinhos de areia, a pele da terra, as pedrinhas menores, as formiguinhas passeando no chão de uma distância. E tonteava.

João Guimarães Rosa, Campo geral

[...] o sintoma se resolve por inteiro numa análise linguajeira, por ser ele mesmo estruturado como uma linguagem, por ser a linguagem cuja fala deve ser libertada.

Jacques Lacan, Escritos

O sintoma, por natureza, é gozo, não se esqueçam disso, gozo encoberto [...].

Jacques Lacan, O seminário. Livro 10: a angústia

\subsection{A ideologia como inversão socialmente necessária da consciência}

Žižek critica o conceito marxiano de ideologia, definido por ele como a inversão das condições efetivas da realidade social pela consciência e como o desconhecimento da distância entre a realidade social e a sua representação distorcida. O filósofo esloveno critica tal noção, reportando-a ao fetichismo da mercadoria. Vamos às palavras de Žižek que explicitam essas nossas afirmações:

\begin{abstract}
A definição mais elementar da ideologia é, provavelmente, a famosa frase de O Capital de Marx: "Sie wissen das nicht, aber sie tun es" "disso eles não sabem, mas o fazem". O próprio conceito de ideologia implica uma espécie de ingenuidade constitutiva básica: 0 desconhecimento de seus pressupostos, de suas condições efetivas, a distância, a divergência entre a chamada realidade social e nossa representação distorcida, nossa falsa consciência dela [...] será que esse conceito de ideologia como consciência ingênua ainda se aplica ao mundo de hoje? Ainda será atuante hoje em dia?". (ŽIŽEK, 2007a, p. 312)
\end{abstract}

Nessa passagem, ao referir-se à ideologia como consciência ingênua, Žižek reporta-se explicitamente à noção de fetichismo da mercadoria em O capital, de Marx. Segundo o filósofo, a consequência dessa concepção de ideologia acarretaria na crítica ideológica de desvendar a ilusão da consciência ingênua, para que esta pudesse reconhecer as condições sociais efetivas de sua produção. Ao 
desmascarar essas condições, a consciência ideológica poderia, então, dissolver-se e localizar-se fora da ideologia (p. 312). Ou seja, a crítica ideológica consistiria em um movimento que iria da alienação à des-alienação da consciência.

Examinemos a concepção de ideologia que Marx e Engels apresentam na primeira parte de $A$ ideologia alemã, pois nossa hipótese é de que justamente essa noção, e não o fetichismo da mercadoria, é que se adéqua à definição de ideologia que Žižek critica na citação acima.

Na primeira parte de A ideologia alemã (MARX; ENGELS, 1845/1846), os autores realizam uma autocrítica por intermédio dos jovens-hegelianos, ${ }^{1}$ um acerto de contas com a consciência filosófica anterior. ${ }^{2}$ Nesse acerto de contas, os autores expõem os princípios fundamentais da concepção materialista de história e de sociedade que desenvolvem a partir do conceito de ideologia em contraposição à abstração especulativa dos "ideólogos alemães" (p. 85).

A ideologia assume papel central nessa obra, como o seu próprio título expressa, e constitui a mediação que explica a produção da consciência pela vida material:

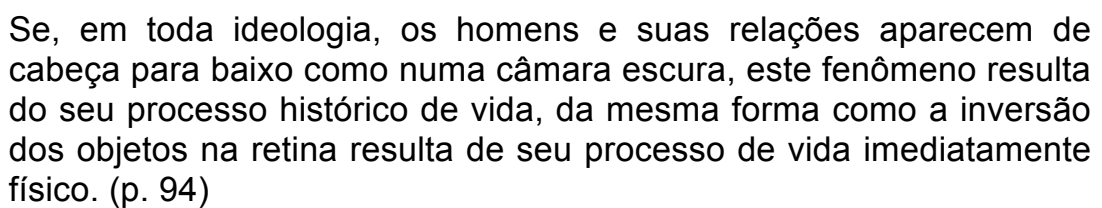

Nessa passagem, Marx e Engels apresentam uma definição de ideologia por analogia a um processo físico. Assim como a inversão dos objetos na retina resulta de um processo físico necessariamente produzido, a inversão dos homens e de suas relações resulta de um processo histórico necessariamente produzido. Os autores concebem a ideologia, portanto, não como erro ou equívoco, mas como inversão da consciência que o processo histórico de vida necessariamente produz. Feuerbach.

1 Principalmente por um dos principais pensadores hegelianos de esquerda, Ludwig

${ }^{2}$ Nas palavras de Marx, em seu prefácio à Contribuição à critica da economia política, tratava-se de "acertar as contas com a nossa antiga consciência filosófica" (MARX, 1859, p. 47). Palavras essas mencionadas apenas posteriormente, mais de dez anos após $A$ ideologia alemã (1845/1846). 
E é nesse sentido que, ao se referirem aos jovens-hegelianos, Marx e Engels definem a ideologia como a distorção entre o que eles 'pensavam ser' e o que 'efetivamente eram', como numa câmara invertida, como numa ilusão.

Para esses "ideólogos alemães, os jovens-hegelianos, a Alemanha teria passado nos últimos anos por uma revolução sem igual" (p. 85), por terem realizado uma interpretação crítica do mundo, mas efetivamente nada fizeram além de realizar outra interpretação. ${ }^{3}$

Essa revolução teria ocorrido no terreno do pensamento puro, que Marx e Engels identificam como "o processo de apodrecimento do espírito absoluto" (p. 85). A partir da distorção entre o que pensavam ser e fazer e o que efetivamente eram e fizeram, esses autores afirmam a necessidade de uma crítica à crítica dos jovenshegelianos e desenvolvem uma outra concepção de crítica, ao buscarem "um ponto de vista situado fora da Alemanha" (p. 86), ou seja, um ponto de vista exterior à filosofia alemã ou pós-hegeliana. ${ }^{4}$

Os filósofos jovens-hegelianos nunca teriam se perguntado "sobre a conexão entre a filosofia alemã e a realidade alemã, sobre a conexão de sua crítica com seu próprio meio material" (p. 84). A crítica não teria passado de uma crítica das representações (religiosas), e era preciso, portanto, elaborá-la sobre "um ponto de vista" exterior a essa filosofia, caso contrário ela recairia na esfera da representação, da filosofia, da vida mental alemã.

Marx e Engels expõem, assim, o ponto de vista da história e da vida social:

Os pressupostos de que partimos não são pressupostos arbitrários, dogmas, mas pressupostos reais, de que só se pode abstrair na imaginação. São os indivíduos reais, sua ação e suas condições materiais de vida, tanto aquelas por eles já encontradas como as

${ }^{3}$ Em Teses sobre Feuerbach, de Marx, a conhecida "Tese 11" explicita bem essa crítica: "Os filósofos apenas interpretaram o mundo de diferentes maneiras; porém, o que importa é transformáIo" (MARX, 1845, p. 539).

${ }^{4}$ Os autores comparam os jovens e os velhos-hegelianos e apontam suas diferenças, porém concluem que há uma unidade entre ambos, a saber, a concepção idealista de que a relação entre os seres humanos era produto de sua consciência e a crença no absoluto "domínio da religião" (p. 84). Mesmo que os jovens-hegelianos tenham combatido esse domínio como "usurpação" - o qual os velhos-hegelianos saudaram como "legítimo" (p. 84) - ainda assim consideravam que: "O progresso consistia em subsumir também as representações metafísicas, políticas, jurídicas, morais e outras, que eram pretensamente dominantes, à esfera das representações religiosas ou teológicas" (p. 83). Essa mesma subsunção, os jovens-hegelianos a teriam realizado com a consciência, como "consciência religiosa ou teológica", e com o homem, como o homem religioso (p. 83). 
produzidas por sua própria ação. Esses pressupostos são, portanto, constatáveis por via puramente empírica. (p. 86-87)

O ponto de partida de Marx e Engels é o ponto de vista da realidade efetiva da vida social, e não o das representações, como na conhecida afirmação desses autores: "Não é a consciência que determina a vida, mas a vida que determina a consciência" (p. 94).

Žižek questiona essa definição de ideologia como uma representação ilusória da realidade, já que a concepção que vai desenvolver é de que a própria realidade já se afigura, sempre e em certa medida, com alguma mistificação ideológica (ŽlŽEK, 2007a, p. 306). Nesse sentido que ele diz: "A máscara não esconde simplesmente o verdadeiro estado de coisas; a distorção ideológica está escrita em sua própria essência" (p. 312). ${ }^{5}$ A noção de realidade, conforme Žižek, baseado na psicanálise, é a de que não podemos aceder às coisas como elas realmente são, à realidade "nua e crua", por isso que o filósofo considera imprescindível evitar as metáforas do desmascaramento, dos véus que esconderiam a verdadeira realidade.

Por meio da ideologia concebida como ilusão, Marx e Engels discutem de que forma a produção material da vida produz uma representação ou uma consciência necessariamente invertida, que não é direta da vida social. ${ }^{6}$ Podemos, então, perguntar como se daria a produção invertida da consciência que, como os próprios autores explicitam, não é resultado direto da vida social; como se daria esse processo de inversão e de separação ou descolamento entre ambas. ${ }^{7}$ Marx e Engels

5 Importante ressaltarmos que Žižek, com essa afirmação, não considera que a ideologia seja, então, inevitável, uma fatalidade, ou que toda realidade seja ideológica. Ele se contrapõe a isso, o que consideraria igualmente ideológico. Essa sua afirmação, com base na psicanálise, como veremos, refere-se à distorção fantasmática constitutiva da realidade em contraposição à uma compreensão da realidade como "realismo ingênuo".

${ }^{6}$ A interpretação de que a vida material produziria diretamente a consciência foi realizada justamente pelos marxistas da primeira geração, ou seja, antes da publicação de $A$ ideologia alemã (que ocorreu apenas em 1932), dos Manuscritos econômicos filosóficos de 1844 (publicado também em 1932) e dos Grundrisse (publicado entre 1939 e 1941), obras fundamentais para a compreensão da teoria da história em Marx. Essa primeira geração teria interpretado a história em Marx como mera inversão da dialética hegeliana da história. Assim, haveria uma determinação da consciência direta da vida social.

7 Aqui, em A ideologia alemã, a representação é concebida como falsa. Ou seja, a consciência, devido às condições sociais em que se encontra inserida, reproduz os objetos do mundo de maneira invertida. Por isso, podemos elaborar essas perguntas. Entretanto, de acordo com o primeiro capítulo de O capital, "A mercadoria", a pergunta já não faria sentido, pois Marx não concebe a representação como falsa, mas sim como uma das determinações do conceito de mercadoria. 
buscam a explicação desse processo nos pressupostos da origem da história, já que são as condições históricas e materiais de vida que produzem a consciência. ${ }^{8}$

Notemos que a ideologia, em $A$ ideologia alemã, está o tempo todo às voltas com a questão da consciência e da representação. Se, para esses autores, a representação faz com que os objetos do mundo sejam imediatamente apreendidos pela consciência tal como eles imediatamente aparecem, ou seja, invertidos, então, ela não pode ser falsa. Se os objetos encontram-se de maneira invertida e a consciência assim os apreende, a representação invertida reproduz fielmente os objetos. Dessa forma, a ideologia não pode ser concebida como falsa representação ou como falsa consciência. A representação não é falsa, mas sim parcial, é apenas uma das determinações do objeto. ${ }^{9}$

Os autores estabelecem uma conexão evidente entre ideologia, consciência e realidade, sendo esta compreendida nessa obra sem qualquer interferência de uma dimensão fantasmática em sua constituição. ${ }^{10}$

Retomando nossa questão, Marx e Engels consideram que o primeiro pressuposto da origem da história é a produção humana dos meios de satisfação de suas necessidades: comer, beber, morar, vestir-se, "a produção da própria vida material" (MARX; ENGELS, 1845/1846, p. 33). O segundo pressuposto é de que a satisfação das necessidades engendra novas necessidades. O terceiro é de que o processo de produção da vida humana se vincula também à produção de outras vidas humanas (outra geração) pela procriação - a família. Tais pressupostos constituem momentos coexistentes "desde os primórdios da história e desde os primeiros homens" (p. 34), e não estágios distintos e independentes um do outro.

Para a produção da vida humana e da história, seja qual for a sua forma de produção, requer-se sempre a cooperação entre os indivíduos, uma conexão mútua entre os homens. Um determinado modo de produzir a vida liga-se a um determinado modo de cooperação "que é, ele próprio, uma 'força produtiva”" (p. 34). Trata-se, portanto, de uma cooperação que é "desde o princípio, uma conexão

\footnotetext{
${ }^{8}$ A consciência também interfere na vida material: "[...] as circunstâncias fazem os homens, assim como os homens fazem as circunstâncias" (MARX; ENGELS, 1845/1846, p. 43). A conexão entre ideologia e consciência é evidente.

${ }^{9}$ Conforme veremos no terceiro capítulo, com a análise marxiana da mercadoria.

${ }^{10}$ Veremos isso ao discutirmos a noção de realidade em $A$ ideologia alemã.
} 
materialista dos homens entre si, conexão que depende das necessidades e do modo de produção e que é tão antiga como os próprios homens" (p. 34), podendo assumir essa conexão diferentes formas.

Da necessidade de intercâmbio entre os homens nasce a consciência e a linguagem, esta última como base material da primeira, que não é pura consciência no início, mas resultante da própria produção material da vida e, portanto, desde o seu início, social (p. 34-35).

Começamos a aproximar-nos da questão que formulamos sobre como dá-se, para Marx e Engels, esse processo de descolamento entre a vida social e a inversão da consciência. Os autores primeiro buscam entender a origem da história humana para depois compreender a consciência que se manifesta na história.

A consciência inicialmente se manifesta como "consciência do meio sensível mais imediato", que denominam como "uma consciência puramente animal da natureza (religião natural)", mas também como resultante da necessidade de relacionar-se com outros homens, portanto, incipiente da vida em sociedade, tão animal quanto é a vida social, "uma mera consciência gregária” (p. 35).

Apenas com o desenvolvimento efetivo da 'divisão do trabalho', isto é, da divisão do trabalho entre 'trabalho material' e 'trabalho espiritual' é que a consciência adquire um sentido de uma representação mais elaborada:

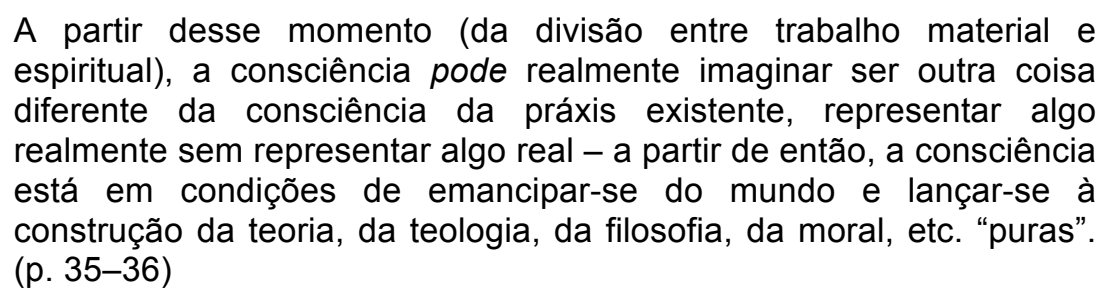

Marx e Engels mostram como a consciência se desenvolve no interior do processo histórico e como, a partir da divisão entre trabalho material e espiritual, ela pode lançar-se a sofisticados constructos teóricos. Mas o que nos interessa é que a consciência pode, então, imaginar-se outra coisa daquilo que efetivamente é, pode, como dizem os autores na citação acima, "representar algo sem realmente representar algo real".

Somente a partir da separação entre trabalho material e espiritual é que a consciência pode imaginar-se diferente - invertida - da vida material existente, autonomizar-se e apreender-se como pura teologia, como pura moral. Portanto, é no 
desenvolvimento efetivo da divisão do trabalho em que reside o descolamento/ separação entre a vida social e a produção invertida da consciência, o que nos perguntávamos. Essa é a definição da ideologia como um processo necessariamente produzido por um fenômeno histórico e social - o desenvolvimento efetivo dessa divisão social - no contexto da crítica de Marx e Engels aos jovenshegelianos.

A divisão entre trabalho material e espiritual, portanto, encontra-se na base da gênese da ideologia, que implica uma leitura do mundo que não é direta da vida social, mas de ponta-cabeça, invertida, ilusória.

Notemos, nesse escrito de Marx e Engels, como a consciência reproduz uma inversão da realidade e também como o desenvolvimento efetivo da divisão do trabalho produz uma distância entre a realidade e a sua representação distorcida. Dito isso, podemos, então, retomar a hipótese que expusemos antes, lançando uma primeira indagação a Žižek: se a ideologia, assim como ele a critica na primeira citação deste trabalho, não se adequaria justamente à concepção de ideologia desenvolvida por Marx e Engels na primeira parte de $A$ ideologia alemã. Pensamos que sim, mas continuemos ainda com esses autores.

Marx e Engels não falam apenas da divisão entre trabalho material e espiritual, ocorrida em algum momento da história, mas também da sua coerção e fixação. Alguns indivíduos coercivamente são fixados na produção material e outros na produção espiritual, passando a haver uma divisão entre trabalho e fruição, entre produção e consumo. Segundo os autores, "divisão do trabalho e propriedade privada são expressões idênticas", expressão de identidade entre atividade e produto da atividade (MARX; ENGELS, 1845/1846, p. 36-37).

O relevante da divisão do trabalho é a forma que ela assume ao longo do processo histórico - no caso do capitalismo, a forma de coerção e de fixação em determinada atividade social. Tal relevância encontra-se na base da separação entre os interesses particulares e os interesses coletivos, e é da contradição dessa separação que o interesse particular assume a aparência de interesse coletivo na 'forma Estado', "uma forma autônoma, separada dos reais interesses singulares e gerais e, ao mesmo tempo, como comunidade ilusória [...]" (p. 37, nota a).

Podemos afirmar, então, que o desenvolvimento da divisão entre trabalho material e espiritual - em que a cooperação assume a forma de coerção e fixação 
da atividade social - consuma-se na realização da forma Estado como "ilusório interesse geral" (p. 37), como "alienação" (Entfremdung $)^{11}$ (p. 38, nota c):

\begin{abstract}
O poder social, isto é, a força de produção multiplicada que nasce da cooperação dos diversos indivíduos condicionada pela divisão do trabalho, aparece a esses indivíduos, porque a própria cooperação não é voluntária mas natural, não como seu próprio poder unificado, mas sim como uma potência estranha, situada fora deles, sobre a qual não sabem de onde veio nem para onde vai, uma potência, portanto, que não podem mais controlar e que, pelo contrário, percorre agora uma sequência particular de fases e etapas de desenvolvimento, independente do querer e do agir dos homens e que até mesmo dirige esse querer e esse agir. (p. 38)
\end{abstract}

O Estado, portanto, também constitui uma ilusão que é produzida necessariamente pelo processo histórico, tendo a sua raiz no desenvolvimento da divisão entre trabalho material e trabalho espiritual. Não resulta do querer e do agir dos indivíduos; pelo contrário, o Estado comanda esse querer e esse agir e torna-se uma "potência estranha", alheia, desconhecida e exterior aos indivíduos. O mesmo processo histórico e social de inversão e ilusão que explica a ideologia explica também a alienação. Ideologia e alienação se apresentam como processos históricos produzidos por funcionamentos semelhantes desde a base de suas constituições.

Chama-nos atenção essa nota 'c' na obra dos autores, na qual eles dizem: "Essa alienação (Entfremdung) para usarmos um termo compreensível aos filósofos..." (p. 38-39, nota c, grifo nosso). Nessa passagem, Marx e Engels nomeiam a ideologia de alienação, deixando margem para pensarmos a ideologia como alienação, ambas como processos históricos equivalentes. Retomemos aqui também a nota 6 desta pesquisa, na qual dissemos que $A$ ideologia alemã só foi publicada na íntegra em 1932, portanto, não foi nunca publicada por Marx, o que nos leva a perguntar se ele caucionaria o termo "ideologia". Além do mais, em O capital,

11 Segundo Silveira (1989), não costuma haver nas edições em português uma tradução rigorosa dos substantivos Entfremdung e Entäusserung. Ou se traduz ambos por alienação ou deixase o Entfremdung para a alienação e o Entäusserung para exteriorização: "Entäusserung designa alienação, um processo referido a alguma forma de perda, de privação, por parte de um sujeito e Entfremdung designa um estranhamento, um alheamento (implicando a autonomização de um poder hostil), que se situa do lado do objeto, ainda que seja referido a um sujeito. Como se a perda por parte do sujeito (alienação) se transferisse, se deslocasse para o objeto (estranhamento)" (p. 193, nota 3). 
Marx nunca utiliza esse termo, mas sim usa 'fetichismo da mercadoria', o que abre margem também para nomearmos o fetichismo da mercadoria como alienação. ${ }^{12}$

A divisão entre trabalho material e espiritual também constitui a base de outra definição de ideologia em $A$ ideologia alemã, concebida como o resultado de um processo de dominação, da "ideologia como as ideias da classe dominante como as ideias dominantes":

\begin{abstract}
As ideias da classe dominante são, em cada época, as ideias dominantes, isto é, a classe que é a força material dominante na sociedade é, ao mesmo tempo, sua força espiritual dominante [...] As ideias dominantes não são nada mais do que a expressão ideal das relações materiais dominantes, são as relações materiais dominantes apreendidas como ideias; portanto, são a expressão das relações que fazem de uma classe a classe dominante, são as ideias de sua dominação. (p. 47)
\end{abstract}

E mais do que isso, a divisão entre trabalho material e trabalho espiritual também se manifesta dentro da própria classe dominante "de maneira que, no interior dessa classe, uma parte aparece como os pensadores dessa classe como seus ideólogos ativos, criadores de conceitos [...]" (p. 47-48). Esses conceitos e ideias, quando separados dos indivíduos dominantes e das relações de produção que os produz, se tornam "a ideia (abstraída das ideias) como o dominante na história, concebendo com isso todos esses conceitos e ideias singulares como 'autodeterminações' do conceito que se desenvolve na história” (p. 49).

A ideologia novamente aparece na mediação do descompasso e da ilusão entre a vida material e a consciência que a representa, entre a história efetiva e a historiografia da época:

\begin{abstract}
Enquanto na vida comum qualquer shopkeeper sabe muito bem a diferença entre o que alguém faz de conta que é e aquilo que ele realmente é, nossa historiografia ainda não atingiu esse conhecimento trivial. Toma cada época por sua palavra, acreditando naquilo que ela diz e imagina sobre si mesma. (p. 50)
\end{abstract}

\footnotetext{
${ }^{12}$ Não estamos sozinhos nessa consideração. Silveira (1989), conforme veremos, nos afirma que a alienação, em Marx, completa o seu movimento conceitual com o fetichismo da mercadoria em O capital (p. 63). Ademais, George Lukács considera o fetichismo a forma específica da alienação no capitalismo (LUKÁCS, 1963, p. 519).
} 
Os autores apresentam agora a crítica ideológica como uma crítica da historiografia existente na época, principalmente, da filosofia hegeliana da história. A definição de ideologia requer, portanto, para Marx e Engels, o desenvolvimento de uma concepção materialista da história e da vida social, que esses autores buscam na gênese do processo histórico que funda o mundo humano.

Após a discussão da primeira parte de $A$ ideologia alemã, podemos retomar com mais firmeza nossa consideração de que a crítica que Žižek dirige à concepção marxista de ideologia se adéqua, especificamente, à concepção desenvolvida por Marx e Engels. Fica evidente que a visão do filósofo esloveno da ideologia, concebida como a distância entre a consciência e o seu desconhecimento distorcido da realidade efetiva, ajusta-se perfeitamente a essa noção de $A$ ideologia alemã. $\mathrm{E}$ veremos em que sentido essa crítica de Žižek não se adéqua ao conceito de fetichismo da mercadoria, de Marx, na medida em que esse conceito abarca uma noção mais complexa.

\subsection{Alienação e sintoma}

Feitas essas considerações, voltemos a Žižek, que aponta para a necessidade de avançar no conceito de ideologia como inversão e desconhecimento da consciência (ŽIŽEK, 2007a, p. 312). No contexto do questionamento desse conceito em Marx - o qual, conforme defendemos, pensamos dialogar com a concepção d'A ideologia alemã e não com o fetichismo da mercadoria d'O capital Žižek propõe uma homologia entre a ideologia como desconhecimento da consciência e a concepção inicial de sintoma na psicanálise.

Essa semelhança estrutural entre ideologia e sintoma - ou entre alienação e sintoma - é um dos argumentos de Žižek, ao elaborar uma noção de ideologia que possa avançar em relação a um mero desconhecimento da realidade. $O$ filósofo considera que a estrutura da ideologia não se configura na forma de um sintoma, definido como um desconhecimento por parte do sujeito, de modo que a interpretação do sintoma acarretaria a sua dissolução. Assim como o sintoma, a ideologia, também definida como um desconhecimento, poderia igualmente ser dissolvida, na medida do seu desvendamento e do seu conhecimento por parte dos sujeitos (p. 306). O sintoma, ao qual o sujeito se encontraria alienado, poderia ser interpretado e dissolvido. Por meio da des-inversão da consciência alienada, poderia 
se passar a sua des-alienação, e a consciência colocaria a realidade com a cabeça de volta para cima.

Freud, ao escutar as histéricas e o sofrimento causado por seus sintomas, rompe com a noção do sintoma na medicina e na psiquiatria de sua época e descobre que os sintomas neuróticos possuem um sentido e uma conexão necessária com a vida de quem os produz. O sintoma, de acordo com o discurso freudiano, deixa de afigurar-se como mero distúrbio orgânico perturbador da saúde a ser eliminado e passa a ser transmissor de uma verdade recalcada pelo sujeito devido a conflitos psíquicos inconciliáveis (FREUD, 1916/1917a, passim).

Em suas Conferências introdutórias sobre a psicanálise (1916/1917), sob o pano de fundo da relação entre a psicanálise e psiquiatria, Freud extrai inúmeras formulações teóricas a partir da análise dos sintomas neuróticos em sua experiência clínica psicanalítica. Mostra-nos, nessas conferências, como os sintomas possuem sentido, intenção e conexão com a experiência de vida de seus pacientes, não apenas em seu aspecto geracional ou hereditário, como conhecia a psiquiatria, mas também no aspecto dos processos inconscientes da vida mental de cada sujeito singular.

Em sua conferência Psicanálise e psiquiatria (1916/1917a), Freud aponta os limites da compreensão das neuroses pelos psiquiatras e a contribuição da psicanálise na compreensão do sentido inconsciente dos sintomas. Freud relata o caso de uma amável e bem conservada senhora que chega em seu consultório, trazida pelo genro, tomada por uma ideia absurda. Segundo essa senhora, ela se casara por amor com um proprietário de uma fábrica e tinha um casamento feliz há trinta anos, mas, após uma carta anônima, em que se afirmava que o marido a traía com uma jovem, tivera a sua felicidade destruída. Freud chama a atenção para o "detalhe notório" (p. 259) de que fora a própria senhora quem provocara essa carta, já que havia falado para sua empregada doméstica, com quem costumava manter conversas íntimas, um dia antes do recebimento da carta, que a pior infelicidade de sua vida seria descobrir que seu marido tivesse um caso amoroso com uma jovem. Num ato de vingança a uma rival mais bem sucedida, a empregada enviou a carta anônima, afirmando que o marido da senhora tinha um caso amoroso com essa rival, uma jovem funcionária da fábrica de seu marido. Apesar de a senhora conhecer a fonte da carta e a mentira de seu conteúdo, pois sabia da rivalidade de sua empregada com a outra moça, e, apesar de, inclusive, saber que seu marido 
sempre fora leal e afetuoso, não tendo qualquer fundamento o seu ciúme, ainda assim a sua ideia delirante persistia. Freud nos diz que o delírio passa a se tornar autônomo em relação à carta e aos fatos reais, os quais não tinham nenhuma força frente a sua construção imaginária de ciúme (p. 256-259).

Freud expõe a interpretação desse sintoma ao trazer a informação de que esse medo já existia na senhora, independentemente da carta recebida, e que talvez, ao invés de medo, ela sentia desejo. De fato, a senhora estava intensamente apaixonada por um jovem, o mesmo genro que a levou para consultar Freud, marido de uma de suas filhas, o que jamais poderia admitir conscientemente. Freud, então, interpreta o seu sintoma, ao afirmar que a senhora precisava buscar algum alívio para o peso de sua própria infidelidade, deslocando a intensa paixão pelo jovem genro para o sintoma de ciúmes, de modo que a "fantasia da infidelidade de seu esposo agiu assim como uma compressa fria em sua ferida ardente" (p. 260).

Freud levanta vários outros questionamentos acerca desse sintoma que poderiam ser interpretados e trabalhados, caso a análise tivesse prosseguido. No entanto, com o material que obteve tirou algumas conclusões. O sintoma delirante deixou de ser um absurdo e ininteligível, adquiriu um sentido e não ocorreu por acaso - tinha o seu fundamento na história singular de vida da senhora. Outro ponto é que o caráter delirante desse sintoma e a sua resistência a qualquer consideração da realidade ocorreram devido à conexão necessária do delírio com um processo mental inconsciente, interpretado por Freud a partir das associações da paciente. Ele afirma que esse "delírio era, em si, de certa maneira desejado, uma espécie de consolação" (p. 260). Por último, Freud conclui que o fato de o delírio ser necessariamente delírio de ciúme foi determinado pela experiência existente por detrás da doença, na medida em que a senhora dissera à empregada, um dia antes da carta que a pior coisa que the poderia acontecer seria a infidelidade do marido (p. 260).

Atentemos agora para duas afirmações fundamentais de Freud acerca do sintoma, em sua conferência intitulada O sentido dos sintomas (1916/1917b), do mesmo ano e também no contexto da discussão freudiana sobre a relação entre psiquiatria e psicanálise: "a psiquiatria clínica atenta pouco para a forma externa do conteúdo dos sintomas individualmente considerados, que a psicanálise, entretanto, valoriza precisamente este ponto e estabeleceu, em primeiro lugar, que os sintomas têm um sentido e se relacionam com as experiências do paciente" (p. 265). Nessa 
conferência, Freud também explicita a possibilidade de uma dissolução total do sintoma, quando afirma que "na psicanálise, constatamos que é possível eliminar permanentemente esses estranhos sintomas obsessivos, assim como outras queixas, e, também, em pessoas não degeneradas. Eu próprio logrei repetidos êxitos neste ponto" (p. 268).

Essas afirmações freudianas sobre o sentido singular dos sintomas e a possibilidade de sua completa dissolução explicitam o conceito de sintoma freudiano nessa época da psicanálise. O sintoma possui um sentido, ao qual o paciente se encontra alienado e a ser interpretado por um alguém, o analista, que sabe e que, ao interpretá-lo, tem o poder de dissolvê-lo. Notemos, nessa conferência, a seguinte passagem de Freud: "Jamais se constroem sintomas a partir de processos conscientes; tão logo os processos inconscientes pertinentes se tenham tornado conscientes, o sintoma deve desaparecer" (p. 287).

Notemos, logo em seguida, referindo-se a Breuer e sua paciente Anna O., outra afirmação freudiana: "E, dessa maneira, Breuer recuperou sua paciente histérica - isto é, libertou-as de seus sintomas; encontrou uma técnica de trazer à consciência os processos mentais inconscientes que continham o sentido dos sintomas, e os sintomas desapareceram" (p. 287).

Nessa época, Freud dizia que o sintoma desapareceria completamente se o paciente conhecesse o sentido inconsciente de seu sintoma, afirmando inúmeras vezes a necessidade de tornar consciente o que foi recalcado pelo paciente. $O$ paciente, ao poder integrar em sua cadeia simbólica o sentido inconsciente de sua ação sintomática, ficaria livre de seu sintoma. Por exemplo, em sua conferência Transferência (1916/1917d), Freud insiste muito nessa ideia, ao dizer repetidamente: "Aquilo que empregamos sem dúvida deve ser a substituição do que está inconsciente pelo que é consciente [...] Transformando a coisa inconsciente em consciente, suspendemos os recalques, removemos as precondições para a formação dos sintomas [...] Podemos expressar o objetivo de nossos esforços em diversas fórmulas: tornar consciente o que é inconsciente, remover os recalques, preencher lacunas da memória" (p. 437).

Entretanto, notemos também em duas passagens, uma em $O$ sentido dos sintomas e outra em Transferência, respectivamente, que Freud já problematizava a simples comunicação racional do analista ao paciente, ao afirmar que as coisas não eram tão simples assim e que um mero conhecimento racional do sintoma não 
bastava, que "o conhecimento deve basear-se numa modificação interna no paciente" (FREUD, 1916/1917b, p. 289). E em Transferência (1916/1917d), o psicanalista diz:

\begin{abstract}
Houve uma época em que pensávamos ser isto algo muito simples: tudo o que tínhamos de fazer era descobrir esse material inconsciente e comunicá-lo ao paciente. Já sabemos, porém que este é um erro primário. O nosso conhecimento acerca do material inconsciente não é equivalente ao conhecimento dele; se lhe comunicamos nosso conhecimento, ele não receberá em lugar de seu material inconsciente, mas ao lado do mesmo; e isso causará bem pouca mudança no paciente. (FREUD, 1916/1917d, p. 438)
\end{abstract}

Podemos notar que Freud não questiona a necessidade de tornar consciente para o paciente o seu material recalcado inconsciente, mas sim a forma como isso se realiza no curso do tratamento. Para ele, apenas a comunicação do saber do analista ao paciente sobre o seu sintoma não era eficaz, na medida em que o saber do analista e o saber do paciente constituem saberes diferentes. Essa passagem citada acima, em Transferência, alude, conforme indicação nesse próprio texto, à discussão que Freud fizera anteriormente em $O$ sentido dos sintomas, no qual diz: "Saber nem sempre é a mesma coisa que saber: existem diferentes formas de saber que estão longe de serem psicologicamente equivalentes [...] O conhecimento do médico [analista] não é o mesmo que o do paciente, e não pode causar os mesmos efeitos" (FREUD, 1916/1917b, p. 288).

Vejamos, na mesma conferência, como Freud elabora algumas formulações teóricas mais gerais sobre o sintoma a partir da análise de um sintoma obsessivo. Ele nos relata que recebera uma jovem senhora que, estranhamente, corria várias vezes por dia do seu quarto para outro quarto contíguo ao seu, onde se posicionava ao lado de uma mesa e, em seguida, tocava a campainha para chamar a empregada e dar-lhe um recado; depois corria de volta para o seu quarto. Esse ato totalmente ininteligível e absurdo, inclusive para a própria paciente, e o qual ela não podia evitar, começa a ganhar sentido com a interpretação que Freud faz a partir das associações da senhora. Há dez anos ela se casara com um homem bem mais velho, que ficara impotente na noite de núpcias. Após esse ocorrido, o marido, por diversas vezes, corria de seu quarto ao dela para tentar a relação sexual, mas continuava impotente. Freud chama atenção para a fala de seu marido numa manhã: "Eu devia sentir-me envergonhado perante a empregada, quando ela 
arrumar a cama" (p. 269). Após dizer isso, o marido derrama uma mancha de tinta vermelha no lençol. Freud percebe algumas conexões entre o sintoma obsessivo e a noite de núpcias: a semelhança entre a correria de sua paciente e de seu marido e a presença da empregada nas duas cenas. Entretanto, apenas estabelece uma conexão entre o ato obsessivo e a macha de tinta após a paciente levá-lo ao quarto contíguo ao seu e mostrar-Ihe uma mancha na toalha da mesa. A paciente relata a Freud que a posição que assumia diante da mesa era tal que ela fazia com que a empregada não pudesse deixar de ver a mancha. Dessa forma, Freud percebe a conexão entre a cena das núpcias e mais esse elemento do sintoma obsessivo.

A paciente, segundo Freud, identificava-se com o seu marido, correndo como ele de um quarto ao outro e, em seu sintoma, a mesa e a toalha substituíram a cama e o lençol. Mas, além disso, Freud nos atenta para a intenção desse sintoma obsessivo que, para além de repetir a cena frustrante da noite de núpcias, a corrige. Opondo-se à fala do marido de envergonhar-se diante da empregada, a senhora mostra a mancha na toalha à empregada para mostrar que seu marido não era impotente e, assim também, para realizar o seu desejo de que seu marido não fosse impotente. Dessa forma, o sintoma obsessivo cumpria a sua intenção, como se estivesse dizendo: "Não, não é verdade. Ele não tinha porque sentir-se envergonhado perante a empregada; ele não ficou impotente" (p. 270).

Ainda em $O$ sentido dos sintomas, Freud também relata a análise de um ritual obsessivo de dormir de uma jovem para mostrar a força do sentido inconsciente dos sintomas. Ambas as mulheres, pacientes de Freud, praticavam os seus rituais repetida e automaticamente, sem qualquer compreensão racional de seus atos e sem estabelecer quaisquer conexões desses atos sintomáticos com as suas próprias vidas. Na sua conferência de mesmo ano, Os caminhos da formação dos sintomas, Freud afirma que as satisfações alcançadas pelo sintoma são estranhas a ele próprio, que aparece como algo irreconhecível para o sujeito devido aos seus mecanismos de 'deslocamento' e 'condensação', resultantes do recalque (FREUD, 1916/1917c, p. 369). ${ }^{13}$ Por isso Freud dizia ser o sintoma tão resistente, por ser um

13 Referimo-nos aqui ao recalque propriamente dito ou recalque secundário, tema que poderemos compreender melhor logo no próximo item (1.3), ao discutirmos sua distinção com o recalque originário e a relação destes com o sintoma. 
conflito entre defesa e desejo, uma formação de compromisso entre duas partes em luta, satisfação e sofrimento (p. 361).

Após descrever e interpretar os rituais dessas duas mulheres, Freud nos diz: "Mostrei-lhes, portanto, com base em dois exemplos escolhidos, que os sintomas neuróticos, como as parapraxias e os sonhos, possuem um sentido e têm íntima conexão com as experiências do paciente" (FREUD, 1916/1917a, p. 276).

Notemos como a concepção freudiana de sintoma, nesse momento de suas elaborações teóricas, enfatiza a sua dimensão simbólica. Os sintomas possuem um sentido e precisam ser significados pelos sujeitos que os produzem para, então, serem simbolizados e, portanto, dissolvidos.

Alguns apontamentos que Žižek realiza sobre o sonho têm uma relação íntima com o sintoma e o utilizamos para pensar duas questões. Assim como Žižek discorre sobre o sonho (ŽlŽEK, 2007a, p. 300), parafraseamos com o sintoma, isto é, apontamos a necessidade de superar a noção de sintoma como mero distúrbio fisiológico, cuja descoberta heterônoma de sua etiologia lhe conferiria inteligibilidade e de dar um passo crucial para sua abordagem hermenêutica, como nos ensinou Freud, de que o sintoma possui um sentido, indicando um "retorno do recalcado" (FREUD, 1915b, p. 183) e possui, portanto, uma verdade recalcada e deformada a ser interpretada e decifrada, lá onde o sujeito a ignora.

A segunda questão aponta para outro acréscimo, para a necessidade de superar o fascínio da significação e do sentido oculto do sintoma, para a necessidade de ir além dessa hermenêutica (ŽIŽEK, 2007a, p. 300). Trata-se de começarmos a questionar o que seria esse "além" a que o filósofo se refere.

O sintoma como um sentido oculto, portanto, condensaria uma verdade recalcada que poderia ser desvelada ao ser interpretado. O mesmo ocorreria, segundo Žižek, com a ideologia como inversão da consciência. A ideologia (acrescentamos: em $A$ ideologia alemã) concebida como o desconhecimento da realidade social oculta e a consciência invertida que essa realidade produziria, poderia ser desvelada e poderíamos aceder à verdadeira realidade social por sua interpretação histórica. Dessa forma, como dissemos a partir de Marx e Engels, colocaríamos de volta os homens e as suas relações de cabeça para cima.

Assim como no início das descobertas freudianas o fundamental era que 0 paciente soubesse a verdade oculta por trás de seu sintoma, em Marx e Engels o fundamental era que o sujeito social desvendasse a verdade oculta por trás da 
ideologia. Sintoma e alienação se configurariam como um desconhecimento, bastando ao sujeito (analisante e proletário) entender a verdade oculta por trás de sua formação sintomática e ideológica, desvelando-a e, consequentemente, dissolvendo-a.

Perguntávamos o que seria esse "além" na afirmação de Žižek sobre a necessidade de superar o fascínio do sentido do sintoma, da necessidade, portanto, de avançar para além da ideologia compreendida como um sintoma simbólico, a ser decifrado. Pois bem, é nesse contexto que Žižek adota a distinção entre sintoma e fantasia, elaborada por J.-A. Miller (ŽIŽEK, 1992, p. 61).

Mas antes disso, adentremos um pouco nos temas do sintoma e da fantasia freudiana, os quais serão importantes no decorrer desta pesquisa. Vejamos um pouco a relação freudiana intrínseca entre realidade e fantasia, alicerce da psicanálise, mas que talvez ainda não seja considerada, com todas as suas consequências teórico-políticas, por algumas análises marxistas e marxianas ${ }^{14}$ que tanto se referem em termos da "realidade efetiva", "realidade objetiva", "fatos reais", dentre outras expressões consagradas pelo marxismo.

A relação entre realidade e fantasia também ganhará toda a sua importância quando Žižek, a partir da psicanálise lacaniana, irá relacioná-las com a ideologia. A fantasia - mais especificamente, o 'real da fantasia' - a realidade e a ideologia adquirem uma conexão que ganhará importância e força na medida em que avançarmos neste estudo.

\subsection{Sintoma e recalque originário: do significante ao gozo}

Conforme vimos em algumas de suas conferências introdutórias, principalmente em $O$ sentido dos sintomas, Freud, em suas primeiras formulações sobre o sintoma, compreende-o como uma formação do inconsciente, portador de uma mensagem desconhecida pelo sujeito a ser decifrada, produto do mecanismo do recalque. Foi assim que Freud concebeu o sintoma no contexto de sua primeira

14 Podemos constatar isso no próprio $A$ ideologia alemã, mas não no Marx a partir de sua análise da forma mercadoria e o seu fetichismo, na qual veremos como a análise marxiana considera a determinação intrínseca da fantasia na produção do fetichismo da mercadoria. 
tópica, ${ }^{15}$ ao descobrir que o sintoma possuía um sentido inconsciente, ou seja, que não ocorria por acaso, mas era determinado pela história de vida do sujeito.

A partir das modificações em sua teoria das pulsões que Freud passa a perceber o limite dessa noção simbólica de sintoma (OCARIZ, 2003, p. 81). O recalque originário (Urverdrängung) constitui um primeiro limite para as possibilidades de significação dos sintomas por ser o mecanismo responsável pela fundação do aparelho psíquico e pela sua divisão em sistema inconsciente e sistema pré-consciente/consciente (OCARIZ, 2003, p. 76-77).

Em seu artigo O recalque (1915), Freud afirma que um dos destinos possíveis de uma pulsão é encontrar resistências que a tornem inativa. Uma pulsão, portanto, pode ter como destino o recalque (FREUD, 1915b, p. 177). Segundo Freud, uma pulsão sucumbiria ao destino do recalque por que o seu objetivo consiste em produzir desprazer, no entanto, a pulsão busca sempre uma satisfação prazerosa. Dessa forma, haveria que existir determinadas condições, nas quais, na economia prazer/desprazer, o prazer fosse transformado em desprazer e a satisfação pulsional gerasse "prazer num lugar e desprazer em outro" (p. 178), sendo que o desprazer adquiriria uma força maior do que o prazer da satisfação.

O recalque, portanto, encontra-se a serviço da satisfação pulsional e, ao mesmo tempo, constitui um mecanismo de defesa contra a pulsão. Mas, precisamos seguir Freud nesse texto para diferenciar recalque de recalque originário. ${ }^{16}$

Uma das condições que Freud destaca para que o recalque ocorra é extraída da experiência psicanalítica com as neuroses de transferência, já que esse mecanismo não pode ocorrer antes da divisão do aparelho psíquico em sistema inconsciente (Ics) e sistema pré-consciente/consciente (Pcs/Cs). Nesse ponto de seu texto, Freud aponta para o recalque como uma defesa que não existe desde sempre, portanto que apenas passa a operar posteriormente, em um aparelho psíquico já dividido entre o Ics e o Pcs/Cs (FREUD, 1915b, p. 178).

O que Freud está dizendo é que, para que o recalque possa operar como destino pulsional, há que ter ocorrido um mecanismo anterior de divisão do aparelho

\footnotetext{
${ }^{15}$ Sistema Inconsciente (Ics) e Sistema Pré-Consciente/Consciente (Pcs/Cs).

${ }^{16}$ Chamamos a atenção para o conceito de recalque originário, o qual servirá de argumento para a nossa discussão sobre fetichismo e inconsciente, no terceiro capítulo, e também terá a sua importância, no quarto capítulo, ao discutirmos as operações lacanianas de alienação e separação.
} 
psíquico, que ele vai denominar de recalque originário, uma primeira fase do recalque. O recalque originário consiste em negar ao representante psíquico da pulsão, ${ }^{17}$ o acesso ao consciente, produzindo uma "fixação" e estabelecendo "ligações" (Beziehungen) da pulsão a esse representante (p. 178-179).

Freud enfatiza nesse contexto a intrínseca correlação entre o recalque e a estrutura das instâncias psíquicas, mais precisamente, a correlação entre o recalque e a diferenciação de consciente e inconsciente ${ }^{18}$ (p. 179).

Mas o que nos interessa aqui é que a fixação e o recalque originário, portanto, são mecanismos anteriores a essa divisão do psiquismo, e o trabalho que realizam é o mais originário: o de uma demarcação interna ao psíquico, o de construção dos momentos iniciais da formação do aparelho psíquico, em que operam destinos pulsionais. Freud dá o exemplo da "transformação no contrário" e do "retorno sobre a própria pessoa" (p. 178). É nesse aparelho psíquico incipiente, ainda em formação, em que o recalque propriamente dito (Verdrängung ${ }^{19}$, um segundo momento do recalque, irá posteriormente operar (p. 179).

Esse material originário $(U r)$, anterior à divisão do aparelho psíquico e anterior, portanto, ao próprio advento do sujeito, constituído de pulsões originárias e de fixações das primeiras inscrições psíquicas, é o material que nos remete ao sintoma para além da sua dimensão simbólica, para o limite do sintoma assim concebido, na medida em que, como falava Ocariz, o recalque originário impõe um limite de conhecimento e de sentido para o sujeito. O recalque originário remete àquilo que escapa da significação do sujeito, sendo impossível de ser integrado em

17 Lacan, no Seminário, Livro 11, faz questão de traduzir a Vorstellungsrepräsentanz freudiana por "representante da representação" - em contraposição a Laplanche e Leclaire, que tentaram corrigi-lo, traduzindo-a por "representante representativo" -, na medida em que não cansa de afirmar que o recalcamento recai sobre o que é da ordem do representante. Insiste, como já o fazia Freud, que o afeto nunca é recalcado, que o afeto "vai passear em outro lugar, onde ele pode" (LACAN, 1964, p. 212). Lacan afirma que nem o afeto, nem o desejo, nem a significação são recalcados, mas o que é recalcado é o representante da representação, aquilo que Lacan irá nomear de "significante binário" (p. 213). O significante, e não a significação, que é recalcado.

${ }^{18}$ Essa explicitação de Freud nos é preciosa se atentarmos para o fato de que $O$ recalque consta de mesmo ano que o seu outro ensaio metapsicológico, intitulado O inconsciente, de 1915, onde Freud realiza um estudo minucioso sobre o que ele concebe por inconsciente, apresentando inúmeras discussões sobre a justificativa de sua existência, a sua dinâmica e topologia, a comunicação entre os sistemas psíquicos etc. Freud, em $O$ inconsciente, já opera com uma concepção clara dessa divisão do aparelho psíquico em sistema inconsciente (Ics) em contraposição a outro sistema psíquico, o sistema pré-consciente/consciente (Pcs/Cs)

${ }^{19}$ Ou recalque secundário, na medida em que equivaleria a um pós-calcar (Nachdrängen), ou apenas recalque. (FREUD, 1915b, p.179). 
sua cadeia simbólica. Ocariz fala de pulsões originárias que não se inscrevem como representação no aparelho psíquico, havendo um quantum pulsional que se inscreve no corpo e que retorna na formação de sintomas como um resto que não se liga com as palavras, com as cadeias significantes (OCARIZ, 2003, p. 48).

O recalque propriamente dito, dessa forma, irá operar em um aparelho psíquico já dividido, afetando os derivados do representante recalcado ou as cadeias de pensamento que entrarem em associação com o representante. Freud também nos diz que o recalque propriamente dito apenas ocorre quando duas forças atuam conjuntamente, a saber, a repulsa do consciente sobre o que tem que ser recalcado e a atração que o material originariamente recalcado (as fixações e as ligações) estabelece com o que pode entrar em associação. Portanto, é necessário haver um material originariamente recalcado para atrair o que é repelido pelo consciente (FREUD, 1915b, p. 179).

Uma das características do recalque, segundo Freud, é a sua alta mobilidade, que exige um constante gasto de energia, em que o recalcado exerce uma contínua pressão em direção ao consciente, compensada por uma contínua contrapressão do inconsciente sobre o material recalcado. Essa característica de mobilidade do recalque explicitaria a divisão do aparelho psíquico, por exemplo, no estado do sono, quando ocorre certo recolhimento do recalque, possibilitando a formação do sonho (p. 181).

O representante pulsional segue mais desenfreadamente se driblar 0 consciente mediante o recalque, seja assumindo deformações, seja pela quantidade de cadeias intermediárias, seja pela distância do material originariamente recalcado. Nesse contexto do recalque (propriamente dito) é que Freud explicita os sintomas como derivados do recalcado que obtiveram acesso à consciência (p. 180).

Arriscamos por nossas próprias palavras, ainda que de maneira imprecisa, a situar os sintomas como formação simbólica na dimensão do recalque e a situá-lo em sua dimensão real, de resto não simbolizável, em termos do recalque originário. Aquilo que foi recalcado pode ser integrado pelo sujeito por encontrar uma inscrição no aparelho psíquico e pode, portanto, ser rememorado em palavras e articulado em sua rede de associações simbólicas. Já aquilo que foi originariamente recalcado não tem como alcançar a dimensão das palavras por constituir-se de pulsões originárias que não alcançam inscrição psíquica como representações e que, portanto, encontram inscrição no corpo ao não se ligarem a um significante. Como vimos, o 
representante psíquico da pulsão (ou o "representante da representação", na tradução de Lacan) tem o seu acesso negado ao consciente pelo mecanismo do recalque originário.

Outro ponto relevante se refere ao fator quantitativo fortemente presente já nesse texto de 1915, quando Freud fala que uma pulsão também pode encontrar-se em estado inativo, ou seja, investida de pouca energia psíquica. Por exemplo, no caso de derivados não recalcados do inconsciente, a medida de ativação ou investimento decide com frequência o destino da ideia. Se o investimento de energia for mínimo, o derivado continua não recalcado. E é nesse momento que Freud aponta que o fator quantitativo se mostra decisivo nesse conflito. No recalque, um aumento no investimento de energia faz com que o recalcado se aproxime do inconsciente, enquanto uma diminuição desse investimento o distancia ou o deforma para o inconsciente (p. 181-182).

O montante afetivo é o outro representante psíquico da pulsão. Esse montante é a parte da pulsão que se desliga da ideia e se expressa como afeto. $O$ destino da ideia que representa a pulsão desaparece do consciente, já o destino do quantum da representante da pulsão pode encontrar, segundo Freud, três vias de destino: ser suprimido, manifestar-se como afeto ou transformar-se em angústia (p. 182-183).

Garcia-Roza nos ajuda a precisar que a representação é o modo ideativo de expressão da pulsão e do afeto, o modo intensivo/quantitativo de expressão da pulsão. Dessa forma, cada representante da pulsão possui um destino diferente. A representação ideativa da pulsão é atingida pelo recalque originário, com vimos em Freud, e tem o seu acesso à consciência interditado. $O$ afeto é suprimido (unterdrückt), deslocado ou transformado. Assim, o afeto é aquela parte do representante pulsional que nunca é propriamente recalcada, sendo apenas de fato recalcadas as representações que ligam o afeto (GARCIA-ROZA, 2000, p. 199202).

Conforme falávamos, em O recalque, de 1915, Freud já faz presente a força da parcela quantitativa da pulsão. Mas, como nos aponta Ocariz, apenas a partir da segunda tópica e do que se concretiza com as modificações na sua teoria das pulsões, em Além do princípio do prazer, que o ponto de vista econômico em Freud irá adquirir a sua força com todas as consequências na psicanálise freudiana, que 
será a formalização da dualidade pulsão de vida-pulsão de morte (OCARIZ, 2003, p. 80).

O montante afetivo da pulsão revela 0 fracasso do recalque que não consegue evitar sensações de desprazer e angústia, ainda que ele consiga alcançar sucesso em relação à parte ideativa da pulsão. Nessa parte ideativa, o recalque produz uma formação substitutiva, ou melhor, Freud nos diz que as formações substitutas e os sintomas indicam um retorno do recalcado (FREUD, 1915b, p. 183).

O recalque originário aponta, portanto, para um saber pleno impossível de ser alcançado pelo sujeito devido ao fato, conforme Ocariz, de não ser uma contingência da biografia, mas anterior a qualquer aparelho psíquico. O recalque originário é, portanto, anterior ao próprio sujeito e mostra a impossibilidade de unificação, de um saber pleno sobre si mesmo e a impossibilidade de uma autoconsciência completa. Haverá sempre um lugar ou resto onde o sujeito não sabe (OCARIZ, 2003, p. 77).

Ocariz discorre em sua obra que Freud, ao notar certo tipo de satisfação paradoxal dos sintomas que produzia sofrimento para além de seu sentido, produzindo satisfação no próprio padecer que não se esgotava no deciframento, passa a se questionar sobre o que impedia o sujeito de elaborar e cessar de repetir seu sintoma (p. 74).

Segundo ela, Freud busca essa resposta no ponto de vista econômico do psiquismo, que adquire o caráter de traumático, como aquilo que não pode ser ligado, um excedente de quantidade que não se processa em palavras que poderiam lhe atribuir uma significação, de uma intensidade sem sentido. A autora cita a passagem de Freud: "[...] uma compulsão à repetição que se instaura mais além do princípio do prazer [...]" (FREUD apud Ocariz, 2003, p. 82). Trata-se, conforme dissemos, de pulsões originárias que não alcançam a inscrição psíquica como representações e que se inscrevem no corpo por não encontrarem ligação a um significante.

Diante desses sintomas pulsionais que retornam, a técnica psicanalítica de interpretação (enquanto decifração) fracassa e o sintoma persiste, e resiste, e insiste, "em sua dupla impossibilidade: alcançar satisfação e deixar de buscá-la" (OCARIZ, 2003, p. 128).

Em termos lacanianos, isso seria um gozo sem-sentido do sintoma, que Lacan denominou de sinthome. Dunker nos indica que a noção lacaniana de gozo 
ocuparia parcialmente o campo energético e quantitativo freudiano (DUNKER, 2002, p. 29).

Dunker localiza que Lacan, após a década de 60, já utilizava a noção de gozo (jouissance) para apontar o fator quantitativo em sua teoria. Entretanto, essa noção apenas adquire consistência após a formalização da instância metapsicológica que Lacan denominou de Real. Conforme Dunker, apesar de não encontrarmos uma equivalência entre os pontos de vista tópico, dinâmico e econômico em Freud e os registros do Simbólico, Imaginário e Real em Lacan, se quisermos localizar "a experiência enquanto acontecimento ou encontro intensivo, inominável e resistente à representação ou à inscrição simbólica, isso certamente residirá no que Lacan chamou de Real e no seu principal correlato clínico que é o gozo" (DUNKER, 2002, p. 26).

Nesse sentido, tanto em Freud como em Lacan, apenas em um segundo momento de suas elaborações teóricas que o sintoma passa a ser compreendido em sua dimensão quantitativa, de gozo. Retomemos Dunker em sua afirmação de que a noção de gozo viria recobrir de maneira parcial o ponto de vista econômico freudiano. Nesse contexto, Dunker diz que "podemos aproximar a segunda vertente freudiana do sintoma a sua dimensão de gozo e suas incidências no plano do Real” (p. 152).

Žižek afirma que falar do sintoma como real parece uma contradição se consideramos a tese de Lacan do inconsciente estruturado como uma linguagem. Entretanto, aponta que o conceito de sintoma pode ser tomado como uma chave para distinguir os diferentes momentos da elaboração teórica de Lacan. Na década de 50, Lacan concebeu o sintoma, assim como Freud, como uma formação simbólica, como uma mensagem cifrada dirigida ao grande Outro, que supostamente sabia o seu sentido. O sintoma já seria formado com vistas a sua interpretação, não haveria sintoma sem destinatário. O sintoma, na "entrada em análise", seria destinado ao analista, esse suposto grande Outro que permitiria ao analisando verbalizar a significação de seu sintoma, o qual, ao ser colocado em palavras, seria dissolvido. O campo da suposição do grande Outro como um campo completo e consistente constituiria o próprio sintoma, na medida em que a sua própria formação consistiria num apelo ao grande Outro, no caso, o analista (ŽlŽEK, 1992, p. 164165). 
Entretanto, apesar da sua interpretação pelo analista, o sintoma não se desfazia, e Lacan explica isso a partir do gozo: o sintoma não constitui apenas uma mensagem cifrada, mas também uma forma do sujeito organizar o seu gozo (p. 165). Por isso, o sujeito jamais renuncia completamente ao seu sintoma.

Dunker, ao discutir o sintoma na família, no contexto das identificações, fala de uma dimensão disruptiva e separadora na identificação ao sintoma familiar, de transmissão geracional, o que conferiria o caráter de singularidade ao sintoma. Dessa forma, o sintoma passaria a configurar-se para além de uma demanda ao Outro. Haveria para Lacan, por um lado, uma regressão aos significantes prescritos da demanda do Outro, regressão que "fixa assim, de forma narrativa e estrutural, os significantes que coordenam a articulação imaginária e simbólica do sintoma" (DUNKER, 2002, p. 150-151). Por outro lado, haveria também uma "terceira incidência da identificação, onde esta recai sobre o traço de gozo que singulariza o sujeito, o objeto a. Trata-se aqui de uma identificação ao sinthoma, expressão cunhada aparentemente para dar forma à solução de gozo expressa no sintoma" (p. 151).

A presença do gozo e de seu "objeto captador de gozo" (p. 153), o objeto a, na concepção do sintoma, abre para o sujeito a possibilidade de articulação de um saber próprio e de separação do Outro (p. 152). Nesse sentido que Dunker situa o sintoma como alienação do desejo e organização familiar e também "como um suporte para a separação ${ }^{20}$ e subjetivação deste desejo" (p. 150). A separação é que conferiria ao sintoma a sua possibilidade de singularidade.

Žižek afirma que, para discorrer sobre a dimensão do gozo no sintoma, Lacan teria procedido em dois momentos. Inicialmente, teria isolado essa dimensão do gozo como a da fantasia, contrastando sintoma e fantasia pelas suas distinções. O sintoma seria uma formação significante que se adiantaria à interpretação, enquanto a fantasia seria uma construção inerte que resistiria à interpretação. Inicialmente, em uma análise, tratar-se-ia de interpretar o sintoma, para depois, por meio dele, penetrar na fantasia fundamental, como núcleo de gozo, e fazer, então, a sua travessia (ŽIŽEK, 1992, p. 168).

${ }^{20}$ Grifos nossos para enfatizar o conceito lacaniano de separação. 
Entretanto, o sintoma ainda persistiria, para além mesmo da fantasia. Diante dessa questão, Lacan teria elaborado o conceito de sinthome:

\begin{abstract}
O sintoma como sinthomem é uma certa formação significante perpassada de gozo: é um significante na medida em que sustenta o goza-o-sentido. Como tal, ele possui um estatuto ontológico radical: o sintoma, concebido como "sinthomem", é, literalmente nossa única substância, o único esteio positivo de nosso ser, o único ponto que dá consistência ao sujeito. Em outras palavras, o sintoma é a maneira como nós, sujeitos, "evitamos a loucura", a maneira pela qual preferimos "escolher alguma coisa (uma forma típica de sintoma) a nada (o autismo psicótico radical, a destruição do universo simbólico)", graças à ligação de nosso gozo com uma certa formação significante que garante um mínimo de consistência a nosso ser no mundo (ŽIŽEK, 1992, p. 169).
\end{abstract}

De acordo com essa passagem, podemos notar que o sinthome marca a presença de um gozo que penetra na rede significante, enredando-se nos planos do simbólico e do real, e explicita o seu paradoxo ao grudar no sujeito como um parasita, mas se for aniquilado, o sujeito perde junto o seu próprio ser (ŽlŽEK, 1992, p. 172). 


\section{DA FANTASIA FREUDIANA AO REAL DA FANTASIA}

[...] O ponto que, para mim, permanecia obscuro na solução da histeria, está na descoberta de uma nova fonte a partir da qual surge um novo elemento da produção inconsciente. O que tenho em mente são as fantasias histéricas [...].

Sigmund Freud, Carta 59 a Fliess

[...] eu não conseguira, ao explorar uma parcela da grande zona que se estendia ao meu redor, mais que afundar para dentro dela aquele incognoscível que é para nós, quando procuramos efetivamente representála, a vida real de uma outra pessoa.

Marcel Proust, Em busca do tempo perdido, A Prisioneira.

\subsection{A noção freudiana de fantasia}

Freud formula a sua "teoria da sedução" a partir da composição de dois acontecimentos $^{21}$ que ocorreriam em dois tempos distantes um do outro. No primeiro, ocorreria uma cena de sedução ativa por parte de um adulto em relação à criança passiva que, diante do comportamento sexual do adulto, não experimentaria qualquer excitação sexual e, portanto, não reagiria por meio de uma defesa (LAPLANCHE; PONTALIS, 1964, p. 28).

Essa primeira cena, portanto, só seria sexual a partir do lugar do adulto perverso, visto que a criança "não [teria] à sua disposição nem as condições somáticas da excitação, nem as representações para integrar o evento" (p. 28). Dentro dessa teoria, essa cena caracterizar-se-ia como "sexual pré-sexual", ou seja, "sexual em si, embora não adquira qualquer significação sexual para o sujeito" (p. 28).

No segundo acontecimento, ocorreria uma segunda cena, localizada aproximadamente na puberdade, quando já se poderia conferir àquela primeira um sentido sexual. Essa segunda cena não possuiria, para Freud, um caráter violento nem ocorreria de forma traumática como a primeira, mas suscitaria associações que remontariam à lembrança da primeira cena, que the conferiria o seu poder de efeito traumático, pois a excitação sexual agora surpreenderia a criança, exigindo o recalcamento da lembrança (p. 28-29).

\footnotetext{
${ }^{21}$ Referimo-nos aqui à primeira teoria do trauma em Freud.
} 
Essa teoria pressupunha, conforme Laplanche e Pontalis, uma sexualidade implantada de fora, do exterior do adulto perverso para o interior do mundo infantil inocente (p. 32-33).

Após essa breve consideração sobre a teoria da sedução, com a ajuda de Laplanche e Pontalis, vamos à Carta 66, de 1897, na qual, envolto com as questões da fantasia, Freud relata a Fliess a força de realidade das fantasias:

\begin{abstract}
Deparamo-nos é com as falsificações da memória e com as fantasias - estas referindo-se ao passado ou ao futuro. Conheço mais ou menos as leis segundo as quais se agrupam essas estruturas e os motivos pelos quais são mais fortes do que as lembranças verdadeiras; assim, aprendi coisas novas que ajudam a caracterizar os processos no Inc. (FREUD, 1897a, p. 349)
\end{abstract}

Freud, ao mencionar as "coisas novas" que aprendeu sobre os processos no sistema inconsciente, fala justamente das fantasias. Aliás, refere-se a estas até como "mais fortes do que as lembranças verdadeiras".

Já na Carta 69, também de 1897 e escrita alguns meses após a Carta 66, Freud anuncia a Fliess o "abandono"22 de sua teoria: "[...] Confiar-Ihe-ei de imediato o grande segredo que lentamente comecei a compreender nos últimos meses. Não acredito mais em minha neurótica"23 (FREUD, 1897b, p. 309).

Nessa carta, Freud enumera os motivos da descrença em sua teoria da sedução: não ter concluído a sua própria análise; as desistências de alguns pacientes e a sua falta de êxito nas análises que estava conduzindo, por não conseguir levá-las até o fim, até um suposto evento patogênico inicial; o fato de que todos os pais teriam de ser considerados pervertidos, caso insistisse nessa sua teoria; a descoberta de não haver indicações de realidade no inconsciente, sendo indistinguíveis verdade e ficção investida de afeto; a reflexão de que na psicose a

22 Aspas por pensarmos que alguns pontos da teoria da sedução ainda permanecem no pensamento freudiano, como os dois tempos do trauma e, em certo sentido, a sedução exercida pelos pais ou pelos cuidadores, na medida em que, cuidando do bebê, erogeinizam seu corpo. Além de que Freud, quando "abandona" a sua teoria por constatar o seu equívoco de que todos os pais teriam que ser pervertidos, retorna a uma realidade acontecida, mesmo que a uma realidade acontecida não mais na história de cada indivíduo, mas na história da espécie, na pré-história, com a sua filogenia (LAPLANCHE; PONTALIS, 1964, p. 83).

${ }^{23}$ Adotamos aqui a interpretação de que, ao dizer "minha neurótica", Freud refere-se a sua teoria da sedução, já não acreditava mais em sua teoria da sedução (LAPLANCHE; PONTALIS, 1964, p. 36). 
lembrança inconsciente não vinha à tona, de forma que, nem mesmo nos delírios mais confusos, o segredo das experiências infantis se revelava (p. 310). Ou seja, frente aos fatos e às dificuldades de sua autoanálise, Freud formula o seguinte questionamento em sua carta: "Será que essa dúvida simplesmente representa um episódio prenunciado de um novo conhecimento?" (p. 311).

De fato, o psicanalista estava diante de novas descobertas, e prestes a dar um giro em sua teoria da neurose. Com esse giro, que foi aos poucos se consolidando, a cena da sedução, que viria do exterior de um adulto perverso, passou a ser compreendida também como uma construção da fantasia da criança para dar conta de sua sexualidade já existente. A cena de sedução passou a ser compreendida não apenas como correspondente absoluta de uma realidade externa acontecida, mas também como resultante dessa construção da fantasia infantil a partir de indícios da realidade. A isso Freud denominou "realidade psíquica" (FREUD, 1916/1917c, p. 370).

Nesse momento do abandono da teoria da sedução, a fantasia assume centralidade na teoria psicanalítica e expressa a necessidade que havia da criação dessa nova categoria conceitual por Freud para poder abarcar teoricamente as suas descobertas.

Freud (1916/1917c) profere que a fantasia possui tanta ou mais força quanto um acontecimento na realidade da infância: "As fantasias possuem realidade psíquica, em contraste com a realidade material, e gradualmente aprendemos a entender que, no mundo das neuroses, a realidade psíquica é a realidade decisiva" (p. 370). Essa constatação de Freud se confirma com a análise do sintoma delirante de ciúme que apresentamos, em que os dados da realidade não tinham nenhuma força diante da fantasia daquela senhora. Do ponto de vista do "mundo das neuroses", ou, em outras palavras, do ponto de vista do inconsciente psicanalítico, ou ainda, do ponto de vista da psicanálise, o que importa é como realidade e fantasia se manifestam, amalgamadas no discurso, como realidade psíquica.

Freud apresenta a noção de fantasia como "algo surpreendente e desconcertante" (p. 369), ao tratar da história infantil na formação dos sintomas, como um fator desconcertante na etiologia do sintoma neurótico. Ao discorrer sobre os caminhos da formação dos sintomas, Freud declara que a libido insatisfeita por uma recusa da realidade regride para alguma organização anterior ou para algum objeto abandonado (p. 362). 
As fixações permitem que a libido transite em situações de conflito e, assim, o investimento regressivo dessas fixações consegue driblar o recalque. Tal drible ocorre pelo fato da libido encontrar fixações que possuem força suficiente para romper o recalque por estarem localizadas em "[...] atividades e experiências da sexualidade infantil, nas tendências parciais abandonadas, nos objetos da infância que foram abandonados. É a estes, por conseguinte, que a libido retorna” (p. 363). Há, dessa forma, algum tipo de satisfação parcial da libido - "satisfação extremamente restrita e que mal se reconhece como tal" - por um "caminho indireto, via inconsciente a antigas fixações" (p. 363).

No texto dessa conferência, o conceito fantasia aparece repetidas vezes na etiologia da formação do sintoma. Quando Freud se pergunta como a libido encontra "o caminho para chegar a esses pontos de fixação", responde:

\begin{abstract}
[...] a libido necessita apenas retirar-se para as fantasias, a fim de encontrar aberto o caminho que a conduz a todas as fixações recalcadas. Essas fantasias gozaram de determinado grau de tolerância: não entraram em conflito com o $e u$, por mais fortes que possam ter sido os contrastes entre ele, desde que seja observada uma certa condição. Essa condição é de natureza quantitativa e é agora perturbada pelo deslocamento da libido para trás, em direção às fantasias. Em consequência desse acréscimo, o investimento de energia das fantasias é de tal modo aumentado, que elas começam a estabelecer exigências e desenvolvem uma pressão no sentido de se tornarem realizadas. Mas isto torna inevitável um conflito entre elas e o eu. Tendo sido anteriormente pré-conscientes ou inconscientes, agora estão sujeitas ao recalque por parte do eu e ficam à mercê da atração por parte do inconsciente. Partindo daquilo que, agora, são fantasias inconscientes, a libido movimenta-se para trás, até às origens dessas fantasias no inconsciente - aos seus próprios pontos de fixação. A retração da libido para a fantasia é um estádio intermediário no caminho da formação dos sintomas. (p. 375)
\end{abstract}

Podemos notar, nesse momento do escrito freudiano, a relação existente entre as fantasias e os sintomas neuróticos. As fantasias inconscientes aparecem como uma das determinações no caminho da formação dos sintomas neuróticos e exercem toda a sua força de atração da libido. Notemos também, nesse texto de Freud, a força do ponto de vista econômico - quantitativo - da libido em direção às fantasias no processo de recalque e de formação do sintoma.

Freud (1908b) assevera que é a partir do significado sexual masturbatório que a fantasia pode, ao não encontrar vias adequadas de satisfação, converter-se em sintoma neurótico para justamente cumprir, parcialmente, a mesma espécie de satisfação que a masturbação propiciava: 
Quando, posteriormente, o sujeito renuncia a esse tipo de satisfação, composto de masturbação e fantasia, o ato é abandonado, e a fantasia passa de consciente a inconsciente. Se não obtém outro tipo de satisfação sexual, o sujeito permanece abstinente; se não consegue sublimar sua libido [...] estará preenchida a condição para que sua fantasia inconsciente reviva e se desenvolva, começando a atuar, pelo menos no que diz respeito à parte de seu conteúdo, com todo o vigor da sua necessidade de amor, sob a forma de sintoma patológico. (p. 165)

Novamente Freud atribui à fantasia inconsciente um estatuto de certa causalidade na formação do "sintoma patológico", quando o sujeito não encontra "outro tipo de satisfação sexual" ou uma via sublimatória. Se não há algum tipo de satisfação sexual, seja pela via do ato sexual, seja pela via da sublimação da libido, a fantasia após tornar-se inconsciente pode atuar como sintoma patológico.

No caso do sintoma histérico, a fantasia pode assumir uma expressão motora através da conversão, uma descarga motora da libido recalcada, ou pode igualmente assumir uma expressão pela via da realização consciente, por meio de encenações de "estupros, ataques ou atos de agressão sexual" (p. 166).

Freud (1908a) compara a natureza da fantasia precursora desses ataques conversivos com a natureza da fantasia formadora dos sonhos, afirmando: "Muitas vezes um sonho pode substituir um ataque, e ainda mais frequentemente explicar 0 mesmo, já que a mesma fantasia se expressa de formas diversas no sonho e no ataque" (p. 233). Essa mesma fantasia, a qual se expressa de inúmeras maneiras, refere-se ao seu significado sexual infantil masturbatório.

As semelhanças na construção das fantasias no ataque histérico e no sonho ampliam-se ainda mais quando Freud aponta características muito parecidas entre os processos de distorção, condensação e inversão da ordem cronológica presentes tanto na representação mímica da fantasia do ataque histérico quanto na formação do sonho, tornando-se ambos ininteligíveis, inclusive para o próprio sujeito (p. 233).

A semelhança entre as diferentes formas de expressão da fantasia - a conversão histérica e o sonho - estende-se também a outro tipo de sua manifestação, denominado de lembrança encobridora. Podemos entender essa forma de expressão da fantasia a partir do exemplo de Freud (1899) ao relatar as observações empreendidas, em 1895, pelos Henris. Um professor de filologia relatava como lembrança mais antiga, a qual localizava por volta dos três ou quatro anos, uma mesa arrumada para uma refeição e sobre ela uma bacia de gelo. Porém, segundo seus pais, nessa mesma época sua avó havia falecido, o que fora um golpe 
muito rude para o garoto, que não tinha qualquer recordação acerca dessa perda. Lembrava-se apenas da bacia de gelo. O conteúdo da lembrança encobridora, a imagem da bacia de gelo sobre a mesa, era o mais nítido e o mais, aparentemente, insignificante. O relevante mesmo estava na perda que o garoto sofrera e não recordava, mas que só poderia ser deduzida a partir do relato do conteúdo da lembrança encobridora (p. 336).

De acordo com Freud (1907), a fantasia também se manifesta como devaneio ou como produção literária, ambos substitutos do brincar infantil. Freud se utiliza da mesma teoria do entrelaçamento da fantasia com o tempo para explicar a formação do devaneio e da produção literária. Expõe que a fantasia flutua em três tempos em que "[...] o passado, o presente e o futuro são entrelaçados pelo fio do desejo que os une" (p. 153). Uma experiência ou uma impressão intensa do presente, capaz de originar um desejo no sujeito, retrocede a uma lembrança infantil em que esse desejo teria sido realizado e cria algo alusivo ao futuro - devaneio ou criação literária - que representa a realização do desejo.

A criação literária, portanto, tal como o devaneio e outras produções fantasísticas, configura-se como correção de uma realidade insatisfatória, porém, por via de um caminho sublimatório da libido. Um caminho que possibilita, inclusive pela distorção que sofre pelo poeta, a satisfação coletiva do público sob a forma de prazer estético e de um prazer ainda maior, de "fontes psíquicas mais profundas", "o prazer preliminar". Os devaneadores podem, por meio do poeta, deleitar-se com seus próprios devaneios sem vergonha ou autoacusações (p. 158).

Freud discorre em diferentes textos ${ }^{24}$ sobre inúmeras manifestações da fantasia - o sintoma, os ataques histéricos, o delírio, o sonho, a satisfação sexual perversa, a lembrança encobridora e as produções substitutas do brincar infantil, como o devaneio e a produção literária - sempre repletas do desejo de cada sujeito que as constrói a partir da sua história singular.

Há também em inúmeros escritos da obra freudiana ${ }^{25}$ algumas produções estruturais da fantasia, consideradas de ocorrência constante na história dos

${ }^{24}$ Fantasias histéricas e sua relação com a bissexualidade (1908), Algumas observações gerais sobre ataques histéricos (1908), Lembranças encobridoras (1899), Sobre as teorias sexuais das crianças (1908), Escritores criativos e devaneio (1907), entre outros.

${ }^{25}$ Conferência XXIII: Os caminhos da formação dos sintomas (1916/1917), Sobre as teorias sexuais das crianças (1908), Romances familiares (1908), Algumas consequências psíquicas da 
primeiros anos da vida dos neuróticos e que seriam típicas e universais, independentemente das experiências singulares de cada sujeito. Por exemplo, em Os caminhos da formação dos sintomas, Freud aponta essas produções estruturais da fantasia como constitutivas da realidade de qualquer ser humano. Essa universalidade impor-se-ia devido à origem filogenética ${ }^{26}$ dessas "fantasias originárias": "Nelas [nas fantasias], o indivíduo se contacta, além de sua própria experiência, com a experiência originária naqueles pontos nos quais sua própria experiência foi demasiado rudimentar". E arremata a possibilidade de que as coisas faladas em análise como fantasias - sedução de crianças, observação do coito dos pais (cena originária), ameaça de castração - equivaleriam a acontecimentos reais de tempos primitivos da família humana (FREUD, 1916/1917c, p. 373).

\subsection{Crítica à noção de realidade como "realismo ingênuo"}

Antes de adentrarmos de vez na implicação que a relação entre realidade e fantasia possuirá para a nossa pesquisa, façamos, conforme indicamos anteriormente, uma breve discussão sobre a noção de realidade em $A$ ideologia alemã e façamos, ainda, algumas considerações acerca da falsa oposição entre realidade e fantasia, a qual viemos, ancorados em Freud, mostrando até então.

Žižek nos atenta para um questionamento sobre a noção de realidade em Marx. Consideramos esse questionamento bastante pertinente no contexto da crítica da ideologia que Marx e Engels nos apresentam na primeira parte de $A$ ideologia alemã.

Os autores traçam uma linha claramente demarcatória entre aquilo que denominam de "realidade efetiva" e "ilusão". De um lado, como vimos no primeiro capítulo com Marx e Engels, "os indivíduos reais, sua ação e suas condições materiais de vida". Do outro lado, "os homens e suas relações [que] aparecem de cabeça para baixo como numa câmara escura" (MARX; ENGELS, 1845/1846, p. 94).

distinção anatômica entre os sexos (1925) e A Organização Genital Infantil: uma interpolação na teoria da sexualidade (1923).

${ }^{26}$ Sempre que Freud tenta explicar a origem (Ur), seja da fantasia, seja do inconsciente (recalque originário), ele recorre à explicação filogenética. A insistência de Freud em explicar a origem da fantasia num evento real acontecido se repete e retorna quando ele introduz a noção de Urphantasien, as fantasias originárias, só que agora em uma realidade não mais acontecida na história do sujeito, mas na história da espécie. 
A partir dessa demarcação, podemos perceber que os autores apresentam a noção de "realidade efetiva" como a realidade, ou seja, como uma positividade totalmente preenchida pelos fatos ditos "efetivos e reais" que a compõem e como objetividade exteriormente acontecida.

Žižek questiona esse conceito, ao afirmar que "[...] a realidade nunca é diretamente 'ela mesma'; só se apresenta através de sua simbolização incompleta/falha" (ŽIŽEK, 2007b, p. 26). Assim, retomamos que, justamente pelo fato de o filósofo esloveno considerar, a partir da psicanálise lacaniana, essa incompletude devido ao furo que a simbolização faz na realidade, deixando restos que produzem efeitos, que ele não poderia considerar toda realidade ideológica ou considerar a ideologia um fatalismo da realidade (como dissemos na nota 5). Žižek questiona a ideologia como simples desconhecimento da realidade, já que comporta sempre alguma distorção inerente.

Para o filósofo, a tentativa de traçar essa linha demarcatória deixa de levar em conta que sempre algo escapa, por haver uma fissura inerente à própria operação da rede simbólica. Diz ele: "[...] a 'realidade', tal como a verdade, nunca é, por definição, 'toda'” (p. 26). Žižek aponta para a incompletude estruturante da realidade devido às falhas nos seus processos de simbolização. Resta sempre algo que escapa à simbolização e, portanto, a realidade nunca pode ser "toda", ou seja, nunca pode ser plenamente preenchida pelos ditos "fatos reais".

O filósofo também assinala certo descompasso existente entre a realidade e a sua própria identidade, portanto ela nunca pode ser diretamente "ela mesma", ela nunca pode coincidir especularmente consigo mesma.

Podemos afirmar, então, que em $A$ ideologia alemã há uma relação identitária entre a realidade e o seu preenchimento positivo pelos ditos fatos reais acontecidos e também entre a realidade e a sua apreensão, mesmo que a realidade se manifeste, ao ser apreendida, como uma ilusão, de ponta-cabeça, como consciência necessariamente invertida e indiretamente produzida pela vida social.

Retomemos algumas passagens de Marx e Engels, as quais expusemos no primeiro capítulo, que nos mostram, ao pé da letra, as nossas considerações sobre essa dicotomia: "Os pressupostos de que partimos não são pressupostos arbitrários, dogmas, mas pressupostos reais, de que só se pode abstrair na imaginação" (MARX; ENGELS, 1845/1846, p. 86-87); "[...] a consciência pode, então, imaginarse outra coisa daquilo que efetivamente é [...]" ou pode "representar algo sem 
realmente representar algo real" (p. 35-36); "Enquanto na vida comum qualquer shopkeeper sabe muito bem a diferença entre o que alguém faz de conta que é e aquilo que ele realmente é [...]" (p. 50).

Nas passagens do texto que acima grifamos, notemos que os autores estabelecem uma separação totalmente demarcada entre realidade e imaginação, como campos absolutamente separados e inconfundíveis. Há uma dicotomia absoluta entre os "pressupostos reais" e a "imaginação", entre o que se imagina ser e o que se realmente é. Há, portanto, uma dicotomia absoluta entre o campo da imaginação e o campo da experiência empírica.

Notemos também que, quando se trata daquilo que alguém "realmente é", não há lugar para qualquer "faz de conta". Marx e Engels, nesse texto, tratam da realidade como se ela pudesse ser concebida tal como ela efetivamente é, completamente destituída de furo, portanto sem falhas em sua constituição simbólica.

Não estamos propondo com esses apontamentos uma volta às abstrações hegelianas e ao mundo das representações. Compreendemos o contexto da crítica materialista da ideologia, de Marx e Engels, dirigida ao idealismo alemão pós-Hegel. É evidente que os autores realizam uma crítica das representações, em que a consciência reproduz os objetos do mundo tal como eles imediatamente aparecem. O que estamos destacando e problematizando é a noção de realidade operante nessa crítica. Essa noção não é algo secundário, pois os autores localizam a ideologia como resultante necessária da realidade.

\subsection{Para além do sintoma: a fantasia}

Dizíamos que Žižek refere-se a um "além" do sentido oculto do sintoma e da leitura sintomal da ideologia que nos direcionou a uma breve apresentação da noção freudiana da fantasia. Percorramos agora no próprio Jacques-Alain Miller a distinção entre sintoma e fantasia que Žižek adota, a qual considera fundamental para um avanço na concepção de ideologia.

Miller não apenas distingue esses dois conceitos, mas os coloca em oposição. Afirma a importância dessa distinção e dessa oposição a partir dos ensinamentos de Lacan e propõe essa divisão clínica como essencial para a “direção da cura" (MILLER, 1983, p. 94-95). 
Miller afirma ser um erro comum pensar que em Lacan tudo é significante. A concepção do inconsciente estruturado como uma linguagem foi somente o ponto de partida. O que Lacan considerou como o seu descobrimento na psicanálise foi o objeto $a$, de que na experiência analítica, nem tudo é significante, mesmo que seja estrutura. Portanto, em psicanálise, há significante e objeto (p. 94).

Esse esclarecimento possui importância, pois o inconsciente estruturado como uma linguagem refere-se à primeira concepção lacaniana do sintoma como uma formação do inconsciente, do sintoma em seu registro simbólico, a ser decifrado. Todavia, essa concepção, como brevemente discutimos, toma outro rumo a partir da elaboração lacaniana do sintoma em seu registro real, em sua dimensão de gozo e de objeto a, o qual ele denominou de "sinthoma".

Após esse apontamento, as palavras de Miller - sobre o inconsciente estruturado como linguagem ter sido apenas o ponto de partida de Lacan, e que esse mesmo afirmou que o seu descobrimento foi o objeto a - adquirem uma contextualização mais explícita em relação ao sintoma, no contexto das formulações teóricas iniciais de Lacan.

Miller recorre ao exemplo da formalização do discurso do analista para mostrar que significante e estrutura não se confundem: a/S2 - \$ (S barrado), onde " $a$ " pertence a estrutura e não é significante. Na estrutura, o objeto a aparece como resultado do significante, e o constitui o seu efeito, o sujeito (p. 97-98). Trata-se, portanto, da existência de sujeito e objeto.

Miller afirma que a oposição entre sintoma e fantasia constitui também uma oposição entre significante e objeto. A articulação significante prevalece no sintoma, embora o objeto também esteja nele implicado. Na fantasia, prevalece o objeto (p. 96)

Reafirmemos que nem tudo no sintoma é significante, senão caímos na possibilidade da sua total significação e dissolução, pertinente apenas às formulações iniciais de Freud e Lacan.

O objeto possui implicação no sintoma, e Miller fala isso ao ser indagado em seu seminário - inclusive dá um exemplo de Freud:

Qual é o descobrimento pelo qual o objeto também se vê implicado no sintoma? É, por exemplo, o de Freud, a reação terapêutica negativa, na qual o que se descobre é a existência de um gozo próprio do sintoma. Gozo paradoxal, porque não é um prazer, é um 
desprazer. Portanto, o objeto a, como "mais de gozar", também está presente no sintoma (p. 107).

Essa passagem explicita que Miller considera, nesse texto, a dimensão de gozo implicada no sintoma. ${ }^{27}$ Inclusive ele fala em "resto dos sintomas" (p. 102) em contraposição à fantasia. Aponta para uma diferença, aliás, entre o que seria o resto do sintoma e a fantasia e evoca o texto freudiano Além do princípio do prazer para dizer que, além desse princípio, está o gozo; e a fantasia seria um meio para articular o gozo com o princípio do prazer. Novamente Miller recorre a um exemplo de Freud, o jogo do fort-da, em que ocorre o domínio de uma situação desprazerosa e angustiante, a ausência do grande Outro materno, e obtém-se prazer através do objeto a (carretel). Miller afirma que esse é um exemplo emblemático de como a fantasia trabalha para obter prazer (p. 102-103). Acrescentamos que para obter dor também, já que o gozo em Freud se articula entre a experiência de domínio e a captura da experiência dolorosa - a mãe que se vai e a sua retomada por seu representante - o carretel.

Para Miller, o sintoma - delimitemos nós que se trata de sua dimensão simbólica - está ligado a certa terapêutica, por isso se fala em "desaparição do sintoma" (ou conforme falávamos em "dissolução do sintoma"), o que não ocorre com a fantasia. Lacan não falava em "desaparição da fantasia", mas da sua travessia (p. 97).

A ordem terapêutica da dissolução do sintoma, segundo Miller, afina-se com a definição do Mestre que Lacan elaborou, aquele que quer que as coisas andem bem, que haja um suposto bem-estar, que as coisas funcionem e encaixem-se na ordem do mundo estabelecido. Isso é bastante contrário à fantasia (p. 97).

Nesse contexto, Miller situa o sintoma, tomado como formação do inconsciente, em relação ao "discurso do Mestre", que é o discurso social. Em contraposição, situa a fantasia em relação ao que Lacan denominou de "discurso do analista". Haveria uma subversão do analista no sentido de seu desejo ir além de um determinado bem-estar, além da eliminação do sintoma e do restabelecimento da ordem (p. 97-99).

${ }^{27}$ Conforme dissemos, há também uma implicação do objeto no sintoma, da mesma forma que Miller afirma que a fantasia possui uma dimensão simbólica. Podemos perceber que sintoma e fantasia se opõem, mas consideramos que parece haver certo limite nessa oposição. 
Notemos aqui que, ao falar do conceito do sintoma como formação do inconsciente, Miller delimita explicitamente o seu registro simbólico. Insistimos nisso, pois, em alguns momentos desse texto, ele nos permite pensar que o sintoma existiria apenas em sua vertente simbólica, o que justificaria a sua ênfase ao opor, de forma generalizada, sintoma e fantasia. Ou seja, se levarmos em consideração a dimensão de gozo do sintoma, essa oposição perde a sua força.

Observemos que o "além" que nos perguntávamos está o tempo todo sendo discutido nesse texto de Miller a que Žižek recorre, e esse "além" aponta para a fantasia, que nos conduz à teoria do gozo em Lacan. A contribuição de Žižek parece ser justamente a de convocar essa dimensão do gozo e, como dissemos a partir de Dunker, a de convocar o "objeto captador de gozo", o objeto a lacaniano, para o campo da ideologia.

Miller realiza inúmeras distinções entre sintoma e fantasia. Traz à tona a sua experiência analítica, apontando algumas distinções em termos fenomenológicos. Assim, o sintoma estaria mais relacionado com o desprazer, com o quanto o analisante fala, e repete, e lamenta, e, novamente, fala, sobre o seu sintoma. A fantasia, por outro lado, assim como o brincar infantil, estaria mais ligada à produção de prazer e consolo, seja em sua manifestação de devaneio ou criação literária. 0 sujeito não se lamenta dela, mas obtém prazer com ela (MILLER, 1983, p. 100-101).

Se, por um lado, os analisantes falam muito de seu sintoma, por outro, são muito reticentes em relação às suas fantasias. Escondem-nas o máximo que podem, como nos ensinou Freud, pela vergonha que sentem devido ao conflito entre os seus valores morais e os conteúdos perversos dessas fantasias (p. 100-102).

Miller discorre também sobre essa distinção em termos da interpretação do analista. O sintoma demanda interpretação do Outro analista; já a fantasia é objeto de construção. A fantasia fundamental ${ }^{28}$ nunca pode ser interpretada, no máximo o que se poderia, em um "fim de análise", seria tangenciá-la, e esse seria o limite de

\footnotetext{
${ }^{28}$ Notemos que aqui Miller fala em "fantasia fundamental", e não mais em "fantasia". Em uma análise, escutamos inúmeras fantasias, com riqueza de personagens e que "[...] a decantação dessas fantasias é um efeito de construção próprio da análise, e nesse caso vamos nos aproximando de fórmulas cuja simplicidade é similar à que Freud nos oferece em Batem em uma criança (MILLER, 1983, p. 104). Com a análise, toda "a selva da fantasia" (referência que Miller faz à expressão de Lacan) caminha rumo a sua simplificação, à "fantasia decantada" (p. 104-105). O que Miller diz ser o fundamental é a sua dimensão real (p.113), e considera que a fantasia fundamental parece corresponder ao recalque originário (p. 105).
} 
uma análise. ${ }^{29}$ Esse ponto limite mostra que fantasia e sintoma localizam-se em lugares diferentes (p. 103-105).

Novamente apontamos aqui para a ênfase que Miller atribui ao registro simbólico do sintoma, ao dizer que ele demanda interpretação. Conforme vimos, quando Freud e Lacan passam a concebê-lo como compulsão à repetição ou gozo, a técnica psicanalítica da interpretação, enquanto decifradora, fracassa, e o sintoma persiste devido ao seu núcleo não elaborável, que não encontra caminhos na cadeia simbólica do sujeito.

Outro ponto que Miller toca é a relação da fantasia com o desejo do Outro, com sua falta, com uma falta no campo do significante, que seria, segundo ele, o que Lacan teria formalizado com o matema A (A barrado). A fantasia constitui, assim, uma resposta ao enigma do desejo do Outro e, exatamente por se localizar nessa falta do significante, não poderia ser objeto de interpretação, mas apenas ser "arranhada" em um "fim de análise" permanecendo como resíduo da interpretação do sintoma (p. 110-111).

A ligação da fantasia (fundamental) com a falta do desejo do Outro interessanos sobremaneira, pois, como veremos com Lacan, ela se dá na operação de separação. Essa operação psíquica produz um intervalo, uma hiância entre o sujeito e o Outro, abrindo espaço para o objeto a, objeto causa do desejo, esse resto implacável que escapa a qualquer significação e interpretação.

Miller não usa o termo "separação", mas é disso que se trata quando ele recorre ao exemplo freudiano do fort-da, em que, diante da ausência angustiante do Outro materno, o pequeno sujeito pode, então, perguntar "Che vuoi?" (O que queres?, em italiano), o que o Outro deseja. Na ausência desse Outro, no caso, a mãe, é que o pequeno sujeito vai poder perguntar pelo desejo do Outro e pelo seu próprio desejo. Nesse contexto, portanto, que adquire significação a seguinte afirmação de Miller: "A fantasia é uma máquina que se põe em ação quando se manifesta o desejo do Outro" (MILLER, 1983, p. 103).

Em nossas palavras, o matema da fantasia nos mostra que a fantasia conjuga sujeito e "objeto causa do desejo" (objeto a), surgindo como uma defesa diante do

\footnotetext{
${ }^{29} \mathrm{Na}$ verdade, o limite de uma análise para Lacan, conforme Žižek nos apontou, vai além da própria travessia da fantasia, e dar-se-ia com o que Lacan chamou, nos últimos anos de suas elaborações, de identificação com o sinthome.
} 
desejo do Outro e, portanto, diante do próprio desejo do sujeito. Podemos extrair dessa citação acima de Miller que separação, desejo, fantasia e objeto a se relacionam, o que terá importância para o nosso argumento mais adiante.

Conforme Miller, Lacan situa o sintoma em termos simbólicos, como qualquer outra formação do inconsciente (chiste, ato falho etc). ${ }^{30}$ Já a fantasia, Lacan, no decorrer de seu ensino, situa-a em termos de três dimensões: a imaginária, a simbólica e a que Lacan teria considerado a fundamental: a dimensão real da fantasia (p. 112-113).

A dimensão real da fantasia equivaleria ao seu próprio resíduo na experiência de análise, que não pode ser modificado e, assim, um fim de análise propiciaria uma mudança na relação do sujeito com esse resíduo real de sua fantasia. Uma mudança além, de uma ordem diferente da do nível (simbólico) do sintoma, já que, para a psicanálise, permanecer no nível da dissolução do sintoma equivaleria a um mero processo adaptativo dos sujeitos à sociedade (p. 113).

Reiteramos, de acordo com Žižek, a importância da distinção entre sintoma e fantasia para a teoria da ideologia. Entretanto, a ênfase de Miller na oposição desses dois conceitos apenas se justifica se ela restringir claramente o sintoma como formação do inconsciente. Caso contrário, repetimos que essa oposição perde a sua força, ao levarmos em conta o sinthoma, que implica a sua dimensão real e de gozo.

\subsection{Da fantasia ao seu real}

Consideramos, junto com Žižek, que a realidade não pode ser concebida como especularidade de si própria ao constatarmos, a partir da psicanálise, a força da fantasia em sua constituição. Em outras palavras, ao constatarmos a força de realidade da fantasia.

Freud, já no final do século XIX, possibilitou-nos apreender a constatação do valor de realidade da fantasia, como vimos na conhecida Carta 69 a Fliess (1897b), em que anuncia o abandono de sua teoria da sedução, fazendo vir à tona essa

\footnotetext{
${ }^{30}$ Nessa passagem, Miller incorre novamente na restrição do uso da noção de sintoma, ao situá-lo apenas em termos simbólicos.
} 
categoria conceitual. As fantasias são construídas a partir de indícios de realidade, e esta, a partir de um complexo de fantasias.

Outro ponto é que também não podemos conceber a realidade como uma positividade plena, preenchida pelos "fatos reais" ao considerarmos as suas partes não simbolizáveis, as suas falhas. Por isso também dissemos, de acordo com Žižek, que a realidade nunca pode ser "toda" e que se apresenta por sua simbolização "incompleta".

Assim, baseado na afirmação de Lacan de que "a distorção e/ou dissimulação é reveladora em si", Žižek comenta que "o que desponta através das distorções da representação exata da realidade é o real - ou seja, o trauma em torno do qual se estrutura a realidade social" (ŽlŽEK, 2007b, p. 31). Portanto, a pretensão de uma visão não distorcida da realidade social, em que se poderia ver a realidade tal como ela realmente é, serviria para elidir, ideologicamente, os efeitos de suas falhas, que se expressariam nessa distorção. Em outras palavras, serviria para suturar o real da realidade, para suturar os efeitos do furo que o simbólico necessariamente produz na realidade, o que seria ideológico.

Um exemplo interessante a que Žižek recorre é o da "luta de classes". No contrafluxo do pensamento hegemônico atual das políticas do multiculturalismo, ${ }^{31}$ o filósofo mantém a noções marxianas de classe e de luta de classes, embora tome esta como aquilo que Lacan considerou como real, como expressão do próprio antagonismo inerente ao social, que o impede de se consolidar "como um todo fechado em si mesmo" (ŽlŽEK, 2007b, p. 31). No capitalismo, a ideologia tentaria justamente elidir esse real da luta de classes, ou seja, elidir o real da realidade, para tapar essa impossibilidade de plenitude social.

A distorção, ao invés de revelar a ideologia, como afirmam Marx e Engels em A ideologia alemã, revela justamente as partes da realidade que não puderam ser simbolizadas. A distorção revela o real fantasmático que estrutura a realidade social (ŽIŽEK, 2007b, p. 31). A distorção, portanto, seria reveladora da realidade social e não encobridora.

O fenômeno do sonho nos mostra isso com clareza, e Žižek estabelece uma relação entre o real lacaniano e o sonho, ao apontar a seguinte afirmação de Lacan:

${ }^{31}$ Políticas de identidade, gênero, etnias etc., contra as quais Žižek empreende críticas ferozes por funcionarem à maneira tolerante do capital e abandonarem a noção de classe. 
"somente no sonho é que chegamos perto do verdadeiro despertar - isto é, do Real do nosso desejo" (LACAN apud ŽIŽEK, 2007a, p. 324). Para Lacan há sempre um núcleo sólido, um resto, que, por nunca poder ser simbolizado completamente, insiste, resiste, persiste e retorna. Lembremo-nos aqui do "umbigo do sonho" em Freud e do poema: "tinha uma pedra no meio do caminho, no meio do caminho tinha uma pedra, tinha uma pedra no meio do caminho...".

O sonho, para Lacan, aproxima-nos da estrutura da fantasia que nos determina em nossa realidade. Žižek vai também trabalhar a sua noção de ideologia, portanto, a partir da relação lacaniana entre o sonho e o real e a partir da afirmação lacaniana de que "na oposição entre o sonho e a realidade, a fantasia fica do lado da realidade" (p. 325). Afirmamos, então, que o real (a "realidade" do nosso desejo) fica do lado do sonho.

O autor expõe o conhecido sonho, interpretado por Lacan, do pai que adormece após a morte do filho, de quem estivera ao lado dias e noites inteiras quando enfermo. O pai, então, produz o seguinte sonho: o filho estava de pé junto a sua cama, puxava-o pelo braço e sussurrava em tom de censura: "Pai, não vês que estou queimando?". O pai acorda nesse momento e percebe um clarão vindo do quarto ao lado, onde o corpo do filho era velado por um velho vigia que adormecera, tendo a mortalha e um dos braços do filho sidos queimados por uma vela acesa que tombara (ŽIŽEK, 2007a, p. 322).

Žižek nos apresenta a interpretação lacaniana desse sonho, em que o pai constrói um sonho que prolongue o seu sono para não despertar para a realidade. Mas, quando o pai se depara em seu sonho com o real de seu desejo - a realidade da censura do filho, "Pai, não vês que estou queimando?", que implica a sua culpa fundamental - nesse sonho, ele acorda. E o pai acorda para fugir do Real e voltar à realidade externa que lhe é bem menos apavorante que o sonho que seu desejo anuncia: "[...] foge para a chamada realidade para continuar a dormir, para manter sua cegueira, para escapar de despertar para o Real de seu desejo" (p. 322-323). Nesse sentido que, para Lacan, apenas no sonho nos aproximamos do verdadeiro despertar, o real de nosso desejo.

Ocorreria algo semelhante com a ideologia, a qual não consistiria em uma ilusão ou um sonho que construímos para fugir da realidade insuportável, mas seria a própria realidade como fuga de um núcleo social traumático que escapa a nossa simbolização. A ideologia constituiria, dessa forma, uma construção de fantasia para 
servir de esteio a nossa realidade, "uma ilusão que estrutura as nossas relações sociais reais efetivas e que, com isso, mascara um insuportável núcleo real impossível [...] uma divisão social traumática que não pode ser simbolizada [...]" (p. 323).

A construção da fantasia serviria de esteio da ideologia para suturar o real, efeito traumático do furo na realidade social que não pode ser simbolizado, conforme vimos com o exemplo da luta de classes, em que a ideologia construiria a fantasia de uma sociedade harmônica, ao tentar elidir o seu núcleo real traumático (a luta de classes), que desmente essa suposta harmonia.

Para o filósofo, tentarmos escapar do sonho ideológico, de maneira a abrir os nossos olhos para ver a verdadeira realidade, como se tirando nossos óculos ideológicos, pudéssemos desvendá-la, seria uma tarefa em vão. Assim como no sonho do pai, a maneira de confrontar com o nosso sonho ideológico seria nos confrontarmos com o real do nosso desejo anunciado nesse sonho. Confrontarmonos, portanto, com o real do nosso desejo na ideologia (p. 325).

Para a elaboração de suas teses, não interessa a Žižek a ideologia como fantasia puramente imaginária, mas a sua dimensão real, na qual a fantasia serve para preencher o furo na realidade, de forma a produzir, de maneira totalizante e, portanto, ideológica, o seu fechamento.

Žižek percebeu essas "defasagens", se é que podemos assim dizer, na teoria marxiana da ideologia. Ao elaborar a sua crítica, na interface entre o marxismo e a psicanálise lacaniana, o autor nesse ponto enriquece a sua crítica a partir da noção lacaniana de "real da fantasia" que, ao constituir a realidade social e a ideologia, passa a funcionar como um operador político de crítica social.

Safatle $(2003)^{32}$ considera que, ao abordar a ideologia a partir da fantasia como categoria política, Žižek teria operado uma "mutação do próprio sentido de “crítica”' (p. 187). A noção psicanalítica de fantasia adquire sentido político, na medida em que Žižek apresenta a noção de "fantasia social" que consistiria em construir uma "objetividade fantasmática" - cujo nome próprio é ideologia ou fantasia ideológica - contra a angústia produzida frente à inadequação do desejo humano aos objetos empíricos, já que o desejo constitui pura negatividade (p. 189).

\footnotetext{
${ }^{32}$ No posfácio de Bem-vindo ao deserto do real! (2003), de Slavoj Žižek.
} 
A fantasia social, assim, serviria para desmentir essa negatividade radical do sujeito, com o intuito de "criar uma realidade consistente na qual nenhum antagonismo Real, nenhuma inadequação intransponível [pudesse] ter lugar e tudo se dissolve[sse] na positividade harmônica de um gozo sem falhas" (p. 189).

O sentido político que o real da fantasia assume na construção da teoria da ideologia em Žižek se encontra na construção de uma teoria que não fique restrita a revelar o que não vai bem ou o que está oculto, ou seja, que não se limite a uma leitura sintomal da ideologia.

Em Lacan, a fantasia possui o seu real no objeto a, servindo de esteio ao desejo, conforme vimos com o matema da fantasia, $\$ \vee a$. Dessa maneira, pensamos que a contribuição de Žižek teria sido, a partir da distinção milleriana entre sintoma e fantasia, trazer para a teoria da ideologia a teoria do gozo e do objeto a. Objeto este que será abordado a partir da operação de separação, elaborada por Lacan em $O$ seminário, livro 11. Entretanto, ainda precisamos compreender como a fantasia se liga a essa operação de separação e como fantasia e separação se ligam à ideologia.

Žižek busca na alienação do fetichismo da mercadoria a forma mais elementar da ideologia (ŽlŽEK, 1992, p. 59) Marx, ao falar do caráter místico da mercadoria, afirma que no lugar das relações sociais aparece uma relação fantasmagórica entre coisas, em que a mercadoria mesma passa a dançar por si mesma. (MARX, 1867, p. 70). Vejamos como o fetichismo da mercadoria possui a sua força nas fantasmagorias que pairam sobre esse objeto que é a mercadoria.

O filósofo fundamenta que a fantasia constitui o esteio da ideologia - em sua distinção do sintoma, como vimos -, por isso ele vai dizer "fantasia ideológica" (ŽIŽEK, 1992, p. 61). Porém, argumenta que "a forma mais elementar da ideologia", o fetichismo da mercadoria, deve ser lido a partir do deslocamento de seu local de incidência, em que o desconhecimento ideológico deve ser localizado no fazer e não no saber humano. Primeiramente, adentremos a forma mercadoria e o seu fetichismo em Marx para, depois, analisarmos essa mudança que Žižek propõe. 


\section{O FETICHISMO DA MERCADORIA E A SUA RELAÇÃO COM O INCONSCIENTE E A FANTASIA}

[...] se trata de la forma específicamente capitalista de la alienación, o sea de lo que luego Marx llamará fetichismo.

George Lukács, El joven Hegel y los problemas de la sociedad capitalista

Se as mercadorias pudessem falar, diriam: É possível que nosso valor de uso interesse ao homem. Ele não nos compete enquanto coisas. Mas o que nos compete enquanto coisas é nosso valor. Nossa própria circulação como coisas mercantis demonstra isso. Nós nos relacionamos umas com as outras somente como valores de troca.

Karl Marx, O capital

\subsection{A forma mercadoria e as suas determinações}

No prefácio da primeira edição de $O$ capital, Marx estabelece uma analogia com a biologia, ao considerar mais fácil estudar a célula do corpo do que estudar o corpo desenvolvido, e anuncia: "Para a sociedade burguesa, a forma celular da economia é a forma de mercadoria do produto do trabalho ou a forma do valor da mercadoria" (MARX, 1867, p. 18).

Com essa analogia, Marx aponta para uma questão epistemológica fundamental: iniciar a sua análise do capitalismo pela forma que considera a mais celular para dela apreender as leis que regem o objeto mais desenvolvido. É por esse motivo que Marx parte, no primeiro capítulo do livro I d'O capital, da análise da forma mercadoria, pois, é a partir da análise dessa "forma celular" que irá apreender as leis gerais do "corpo desenvolvido" - as leis gerais do capitalismo.

Nesse capítulo, Marx inicia a sua análise a partir da mercadoria em sua aparência imediata aos nossos sentidos, trivial e valor de uso, de maneira que ela serve para a nossa utilidade e necessidade, seja essa necessidade proveniente "do estômago ou da fantasia" (p. 45) - interessante notarmos que, para Marx, a necessidade pode provir da fantasia.

A utilidade de uma coisa constitui o seu valor de uso e é determinada pelas propriedades do corpo da mercadoria. O valor de uso é o conteúdo material da riqueza, independentemente da forma social de produção da vida. Especificamente, no capitalismo, o valor de uso é o portador material daquilo que Marx denominou de valor de troca (p. 45-46). 
A partir da troca de objetos que servem à utilidade dos indivíduos, ou seja, da troca de valores de uso cotidianamente praticada pelos indivíduos, Marx elabora uma equação para expressar o valor de troca, denominada de expressão de valor ou forma simples de valor, que, em sua forma "embrionária" e simples, se apresenta como:

x mercadoria $A=y$ mercadoria $B$ ou; $x$ mercadoria $A$ vale y mercadoria $B$
ou
20 varas de linho = 1 casaco; 20 varas de linho vale 1 casaco (p. 54$)$

A partir dessa expressão simples subjacente às trocas de mercadorias, Marx afirma que "algo em comum da mesma grandeza existe em duas coisas diferentes". Por exemplo, "1 quarter de trigo = a quintais de ferro" significa que certa quantidade de trigo iguala-se a certa quantidade de ferro e significa também que ambas são iguais, enquanto valor de troca, a uma terceira mercadoria (p. 46).

Ao dizer que um tanto de trigo e de ferro, enquanto valores de troca, equivalem a uma terceira mercadoria, Marx afirma que "é precisamente a abstração de seus valores de uso que caracteriza evidentemente a relação de troca das mercadorias" (p. 46). Ou seja, há uma abstração operante na troca: o valor de uso das mercadorias é abstraído, já que o "algo em comum" que importa na troca nada tem a ver com as propriedades corpóreas das mercadorias, as quais Ihes conferem utilidade; restando a essas mercadorias como "algo comum" o fato de serem produto do trabalho humano.

Haveria ainda uma segunda abstração, em que, juntamente com a abstração do valor de uso, ocorreria uma abstração dos componentes e formas corpóreas que fazem desse produto valor de uso. Conforme Marx:

\footnotetext{
Ao desaparecer o caráter útil dos produtos do trabalho, desaparece o caráter útil dos trabalhos neles representados, e desaparecem também, portanto, as diferentes formas concretas desses trabalhos que deixam de diferenciar-se um do outro para reduzir-se em sua totalidade a igual trabalho humano, a trabalho humano abstrato (p. 47)
}

Os produtos do trabalho se tornam indiferenciados, já não se trata mais da mesa, da casa, do fio ou de qualquer caráter útil das coisas. Os trabalhos, assim, também se tornam indiferenciados, e já não se trata do produto do trabalho do marceneiro, do pedreiro ou do fiandeiro, restando deles: 
[...] a não ser a mesma objetividade fantasmagórica, uma simples gelatina de trabalho humano indiferenciado, isto é, do dispêndio de força de trabalho humano, sem consideração pela forma que foi despendida. $\mathrm{O}$ que essas coisas ainda representam é apenas que em sua produção foi despendida força de trabalho humano, foi acumulado trabalho humano. Como cristalizações dessa substância social comum a todas elas, são elas valores - valores mercantis. (p. 47)

A partir dessas passagens citadas, podemos extrair a diferenciação daquilo que Marx denomina de trabalho concreto e trabalho abstrato. O trabalho concreto ou útil constitui a produção de um bem segundo uma determinada finalidade ou utilidade, segundo seu valor de uso. Marx refere-se a ele como uma condição da existência humana, a despeito da forma de produção da vida, como "eterna necessidade natural de mediação do metabolismo entre homem e natureza e, portanto, da vida humana" (p. 50). Já o trabalho abstrato é o "resíduo" do desaparecimento do trabalho concreto, é a cristalização da substância social trabalho, o dispêndio de força humana de trabalho indiferenciado, "dispêndio produtivo de cérebro, músculos, nervos, mãos etc. humanos [...]" (p. 50-51).

Assinalamos essas abstrações do valor de uso devido a sua importância para entendermos que o que resta delas é o trabalho abstrato, categoria conceitual relevante para a nossa pesquisa. Ocorrem, portanto, dois movimentos, um movimento de abstração do valor de uso e um movimento de abstração da abstração do valor de uso, que resulta no desaparecimento dos trabalhos concretos, restando apenas trabalho humano indiferenciado, trabalho abstrato, restando apenas, nas palavras de Marx, essa "objetividade fantasmagórica”.

Dessa forma, o que Marx nos mostra, no decorrer de sua análise da troca das mercadorias, é que o "algo comum" é o valor. Essas abstrações operantes na troca das mercadorias revelam o fator valor da mercadoria (p. 47)

Marx retoma o valor de troca das mercadorias para deixá-lo de lado: "[...] o valor de troca, como a maneira necessária de expressão ou forma de manifestação do valor, o qual deve ser, por agora, considerado independentemente dessa forma" (p. 47). Em outras palavras, o que ocorre é uma abstração do valor de troca; agora devemos levar em conta o valor independentemente do valor de troca. O que importa é a determinação valor. Notemos também que Marx aponta para, nas palavras de Silveira, "uma distinção fundamental, que é feita apenas nesta obra [O capital] entre 'valor' e 'forma de valor' ou 'valor de troca'” (SILVEIRA, 1989, p. 64). 
Marx mostra que a dimensão do valor só pode ser alcançada quando se torna possível pensar a equiparação dos diferentes trabalhos (o "algo comum"), ${ }^{33}$ quando se torna possível considerar as mercadorias como produtos do trabalho humano abstrato (substância do valor) e quando se torna possível alcançar a determinação do valor como relação social.

Se Marx alcança a categoria do valor como relação social, então a medida do trabalho é determinada pelo tempo médio de trabalho socialmente necessário ${ }^{34}$ para se produzir um objeto. Não se trata do trabalho individual de cada trabalhador com uma finalidade estabelecida, mas da cristalização do trabalho em geral, o trabalho humano abstrato, como "dispêndio de força de trabalho humano" (p. 47).

Os dois fatores da mercadoria nos levaram a concebê-la como valor de uso e valor, e essa mesma forma dupla a reencontramos no trabalho. $O$ valor de uso apresenta-se como consumação do trabalho concreto ou útil, o qual é realizado conforme um fim determinado. O valor apresenta-se como consumação do trabalho humano abstrato, simples dispêndio de força humana de trabalho.

Alcançamos até aqui duas determinações da mercadoria: 1.) a mercadoria é valor de uso e valor de troca e; 2.) a mercadoria é valor de uso e valor. Essa constatação é de indispensável relevância para podermos apreender o conceito de mercadoria e o seu fetichismo, na medida em que esse conceito vai sendo construído por Marx pelo conjunto de suas múltiplas determinações. Marx, conforme avança em sua análise, não abandona as primeiras determinações da mercadoria, ${ }^{35}$ de maneira que é essa somatória das múltiplas determinações que nos levará ao concreto do conceito de mercadoria e ao objeto de análise.

Marx define, então, que o duplo caráter da mercadoria constitui-se de valor de uso e de valor. Foi necessário abstrair o valor de uso para chegar ao valor, porém, para que um produto se torne mercadoria, ele precisa ser "transferido a quem vai

${ }^{33}$ Segundo o próprio Marx, Aristóteles chegara muito próximo de descobrir o conceito de valor, mas não pôde alcançá-lo devido ao contexto histórico e político da sociedade escravocrata em que vivia, quando jamais era possível pensar em equiparação/igualdade de trabalhos (MARX, 1867, p. 62).

${ }^{34}$ Tempo de trabalho socialmente necessário é "aquele requerido para produzir um valor de uso qualquer, nas condições dadas de produção socialmente normais, e com o grau social médio de habilidade e de intensividade de trabalho" (p. 48).

${ }^{35}$ Conforme dissemos, no primeiro capítulo, Marx não deixa de considerar a representação como uma determinação da mercadoria, como uma primeira determinação, insuficiente e parcial, mas não falsa. 
servir como valor de uso por meio da troca" (p. 49). Isso significa que para existir mercadoria deve haver a utilização do produto por outro (que não seja o produtor) que o obteve pelo ato da troca. Significa também que o valor depende do valor de uso, pois se um produto não for objeto de utilidade por outro, torna-se inútil também o trabalho humano abstrato que ele contém. (p. 49)

Marx parte da análise da troca simples entre duas mercadorias, expressa na forma simples de valor, que mostramos acima. Essa expressão, como vimos, contém uma relação de igualdade entre valores de uso qualitativamente diferentes (linho e casaco), em que 20 varas de linho contêm a mesma substância e grandeza de valor que 1 casaco. Portanto, a forma de valor expressa não apenas valor em geral, mas também a determinação quantitativa de valor ou grandeza de valor. Ou seja, linho e casaco necessitam não apenas serem valores de mesma qualidade, mas também valores de mesma quantidade: "A equação: '20 varas de linho = 1 casaco [...]' pressupõe que 1 casaco contém tanta substância de valor quanto 20 varas de linho, que ambas as quantidades de mercadorias custam assim o mesmo trabalho ou igual quantidade de tempo de trabalho. (p. 57)

Marx nos explica que a forma simples de valor contém duas mercadorias que representam papéis distintos. Na expressão 20 varas de linho $=1$ casaco, o linho expressa seu valor no casaco, o qual serve de corpo, de suporte material para essa expressão de valor.

O valor da primeira mercadoria (linho), portanto, é um valor relativo, e o valor da segunda mercadoria (casaco) é um valor equivalente. Assim, o valor do linho só pode se expressar de forma relativa, ou seja, em relação a uma outra mercadoria que se oponha de forma equivalente e que expresse o valor do linho.

O casaco constitui nessa relação a forma de valor do linho. Segundo Marx, "Por meio da relação de valor, a forma natural da mercadoria B torna-se a forma de valor da mercadoria A ou o corpo da mercadoria B o espelho do valor da mercadoria A" (p. 57).

Essa relação de igualdade entre esses dois tipos de mercadorias apenas é válida dentro dessa expressão de valor e apenas dentro dessa relação, em que o valor natural da mercadoria B funciona como uma forma de valor da mercadoria $A$. Nessa relação, e apenas nela, o corpo da mercadoria $B$ transforma-se para a mercadoria A no espelho de seu valor. 
A forma relativa de valor de uma mercadoria, por exemplo, o linho (naquela expressão 20 varas de linho $=1$ casaco), em sua qualidade de ter valor como algo distinto de seu corpo e de suas propriedades - por exemplo, um casaco - indica que essa expressão oculta uma relação social. Já a forma equivalente de valor, ao contrário, consiste no corpo da mercadoria tal como ela é - o casaco, ele próprio, expressa valor, portanto, possui naturalmente forma de valor, mas apenas nessa relação, em que a mercadoria linho se relaciona com a mercadoria casaco enquanto forma equivalente (p. 60).

Nesse sentido que Marx fala que as mercadorias "[...] possuem a forma de mercadoria apenas na medida em que possuem forma dupla, forma natural e forma valor" (p. 53), e leva-nos a alcançar a terceira determinação do conceito de mercadoria, a forma de valor ou a forma sob a qual o valor é expresso.

Marx, portanto, apresenta a mercadoria como uma coisa útil e como valor de uso. (p. 45), mas, no decorrer de sua análise, passa a mostrá-la "como uma coisa muito complicada, cheia de sutileza metafísica e manha teológica” (p. 70). Marx alcança a definição de mercadoria em suas múltiplas determinações, ao refutar a primeira definição de mercadoria como coisa a serviço das nossas necessidades e ao mostrar o seu fetichismo, expresso na clássica frase: "Não o sabem, mas o fazem" (p. 72).

\subsection{Fetichismo: um lugar (no pensar) para um não saber?}

Marx nos demonstra, ao longo de todo esse capítulo dedicado à análise da forma mercadoria, que o fetichismo da mercadoria significa que os produtos do trabalho ocultam, sob a forma mercadoria, as relações sociais de trabalho, e que os indivíduos, ao trocarem mercadorias, não sabem que estão equiparando diferentes tipos de trabalho.

Segundo Marx, conforme indicamos anteriormente, o fetichismo da mercadoria significa também que, no lugar de relações sociais regidas pelo trabalho, aparece uma relação fantasmagórica entre coisas, que adquirem vida própria, e a forma mercadoria "mesa" desenvolve cismas muito mais estranhas do que se começasse a dançar por si própria (p. 70). Sob o fetichismo da mercadoria, Marx constata que a relação entre os sujeitos e as coisas assume uma inversão. 
Os indivíduos, portanto, ao trocarem mercadorias, não sabem que estão trocando trabalhos de diferentes tipos, os quais podem ser equiparados. Não sabem também que o que aparece como produto do trabalho é relação social de seu próprio trabalho.

Žižek propõe uma mudança na formulação marxiana do fetichismo da mercadoria, ao deslocar a incidência da ilusão fetichista do lugar do saber para o lugar do fazer. Para ele, no mundo atual, os indivíduos sabem perfeitamente que por trás da utilização do dinheiro encontra-se uma relação social; o que não sabem é que, em seu agir, agem como se não soubessem e continuam fazendo o que fazem.

Para Žižek, se considerarmos que a ilusão do fetichismo da mercadoria incide atualmente na esfera do saber humano, conforme a formulação marxiana "Não o sabem, mas o fazem", precisaríamos admitir, então, que já não vivemos mais em sociedades ideológicas. Se os indivíduos sabem, a ilusão fetichista se dissolve. Vejamos isso com um exemplo chave que Žižek utiliza como um de seus argumentos nessa sua crítica, o uso da mercadoria dinheiro (ŽlŽEK, 2007a, p. 316).

O filósofo considera que os indivíduos que se servem do dinheiro sabem muito bem que nele não há nada de mágico, sabem que o dinheiro é simplesmente uma expressão das relações sociais, e chegam até a reduzi-lo a um mero sinal que concede ao indivíduo o direito de dispor do produto social. Para Žižek, os indivíduos sabem perfeitamente ${ }^{36}$ que por trás das relações entre as coisas há as relações humanas, mas, no processo de troca, agem como se o dinheiro "fosse em sua realidade imediata, na qualidade de coisa natural, a encarnação da riqueza”. (ŽlŽEK, 1992, p. 61-2).

Esse "como se" (als ob) (ŽlŽEK, 2007a, p. 303) expressaria exatamente a ilusão fetichista da mercadoria. No ato da efetividade da troca, os indivíduos agiriam como se a mercadoria fosse um bem imutável, indestrutível, como nos exemplifica Žižek em relação ao dinheiro: "Sei que o dinheiro é um objeto material como os outros, mas, ainda assim... (é como se ele fosse feito de uma substância especial, sobre a qual o tempo não tem nenhum poder)". Lembra-nos também do fetichismo em Freud: "Sei que mamãe não tem falo, mas, ainda assim..." (ŽlŽEK, 2007a, p. 303).

${ }^{36}$ Grifos nossos. 
A localização da ilusão na ação significa que é na prática, na realidade, no ato de fazer, que as pessoas estão sob a ilusão fetichista, e não no ato de pensar. Conforme o autor: "eles são fetichistas na prática, e não na teoria" (p. 315). O que os indivíduos efetivamente não sabem é que, no ato da troca de mercadorias, no ato da sua própria realidade social, são guiados por essa ilusão do fetiche (p. 315).

Por esse motivo que Žižek considera que a ideologia não se configuraria como um sintoma a que o sujeito estaria alienado por desconhecê-lo, conforme vimos no primeiro capítulo. Para o autor, é necessária a distinção entre sintoma e fantasia, na medida em que a "leitura sintomal" do texto ideológico já não daria mais conta de explicar, por exemplo, a razão cínica (p. 313).

Na razão cínica já não haveria mais desconhecimento ou ingenuidade (de fazer/agir sem saber), "sabe-se muito bem da falsidade, tem-se plena ciência de um determinado interesse oculto por trás de uma universalidade ideológica, mas, ainda assim, não se renuncia a ela". (p. 313).

Žižek recorre à formulação de Peter Sloterdijk, em sua Crítica da razão cínica, em que esse autor apresenta outra proposição da fórmula do fetichismo de Marx: "eles sabem muito bem o que estão fazendo, mas mesmo assim o fazem" (ŽlŽEK, 2007a, p. 312-313).

Segundo Žižek, na formulação proposta dessa maneira, a ilusão fetichista desaparece, não se encontra nem do lado do saber nem do lado do agir. Eles sabem o que fazem e o fazem. Para Žižek, tanto a fórmula marxiana quanto a de Sloterdijk nos levam a admitir, atualmente, o fim da ideologia, pois os indivíduos já sabem o que fazem e continuam fazendo. (p. 316)

Žižek considera a razão cínica umas das formas atuais da ideologia e considera apressada demais a ideia (ideológica) de que estaríamos vivendo em sociedades pós-ideológicas: "[...] a razão cínica, com todo o seu desprendimento irônico deixa intacto o nível fundamental da fantasia ideológica, o nível em que a ideologia estrutura a própria realidade social" (p. 314).

Žižek reafirma a atualidade da força e da sofisticação ideológica nas sociedades, propondo uma variação da fórmula marxiana do fetichismo: "eles sabem que, em sua atividade, estão seguindo uma ilusão, mas fazem-na assim mesmo" 
(p. 316) ou "Eles não sabem o que fazem". ${ }^{37}$ Os indivíduos sabem e conhecem a sua atividade social, a sua realidade; o que desconhecem é a ilusão que estrutura essa realidade e mesmo assim continuam seguindo esta ilusão e fazendo o que fazem.

Dessa forma, ao deslocar a ilusão fetichista do âmbito cognitivo, do saber, para o âmbito da ação, da própria realidade, Žižek defende que continuamos a viver em sociedades ideológicas.

A razão cínica não escapa à ideologia, pois, apesar de saber o que faz, é no ato de fazer que o cínico é guiado pela ideologia. Isso é o que Žižek denominou de "paradoxo de uma falsa consciência esclarecida" acerca da razão cínica: "O paradoxo da posição cínica só aparece ao identificarmos a ilusão atuante na própria realidade". Se a ilusão se localizasse do lado do saber, a postura cínica seria pósideológica e, nas palavras do filósofo, "simplesmente uma postura sem ilusões: 'eles sabem o que estão fazendo e fazem'” (p. 316). Se não considerarmos esse paradoxo, a ilusão desaparece e afigurar-se-iam, consequentemente, sociedades pós-ideológicas.

Diante do cinismo, portanto, o método de crítica ideológica, baseado na leitura sintomal da ideologia, não funcionaria, já que não haveria como subverter a "consciência cínica" por uma leitura que tentasse confrontar o texto ideológico com os seus pressupostos recalcados. (ŽlŽEK, 1992, p. 60).

Segundo Žižek, já não haveria mais crença nas proposições ideológicas, e é nesse sentido que ele adota a distinção entre sintoma e fantasia para elaborar a sua concepção de que "o nível fundamental da ideologia não é de uma ilusão que mascare o verdadeiro estado de coisas, mas de uma fantasia [inconsciente] que estrutura nossa própria realidade social” (ŽlŽEK, 2007a, p. 315). Žižek localiza a ilusão ao lado do fazer, "daquilo que as pessoas fazem": O que elas não sabem é que sua própria realidade social, sua
atividade, é guiada por uma ilusão, por uma inversão fetichista. O que
desconsideram, o que desconhecem, não é a realidade, mas a ilusão
que estrutura sua realidade, sua atividade social. Eles sabem muito
bem como as coisas realmente são, mas continuam a agir assim
como se não soubessem. (p. 316 )

${ }^{37}$ Título de um de seus livros em que discute a teoria da ideologia: Eles não sabem o que fazem: o sublime objeto da ideologia. 
Essa ilusão ("como se") que o autor localiza na prática cotidiana, na realidade social dos indivíduos, é uma fantasia inconsciente que Žižek denomina de fantasia ideológica.

Podemos constatar que Žižek não adota a crítica da razão cínica ("eles sabem muito bem, mas mesmo assim..."), confusão que muitas vezes ocorre. Ele considera essa crítica de Peter Sloterdijk equivocada por também localizar a ilusão na dimensão do saber humano, assim como Marx com o fetichismo da mercadoria, embora a crítica de Sloterdijk e a de Marx sejam distintas.

Para Žižek, a crítica da razão cínica não atinge, consequentemente, a dimensão fantasmática presente no ato de fazer. O que o filósofo faz é defender a ineficácia do método de crítica da ideologia como sintoma frente à postura cínica. Nesse ponto concordamos com ele, ou seja, diante do cinismo, a ideologia, pensada como desconhecimento ou como sintoma, perde a sua eficácia. Entretanto, a questão que levantamos é se o fetichismo da mercadoria simplesmente se restringiria a um mero desconhecimento ou a uma crítica sintomal da ideologia.

Pois bem, conforme discutimos, de fato, concordamos com a distinção milleriana entre sintoma e fantasia, e consideramos um avanço a inflexão de Žižek de convocar a fantasia e, mais precisamente o gozo e o objeto a, para a teoria da ideologia. Mas, retomemos aqui a nossa indagação e acrescentemos uma segunda: 1.) se essa crítica, em termos de uma leitura sintomal, não se adequaria à noção de ideologia desenvolvida em $A$ ideologia alemã, de Marx e Engels - a qual apresentamos no primeiro capítulo - e não ao fetichismo da mercadoria, o qual abarcaria uma noção mais complexa de ideologia e; 2.) se essa inflexão do filósofo, de deslocar a incidência fetichista do saber para o fazer humano, se aplicaria, assim, genericamente, como ele afirma, a todos os sujeitos sob o fetichismo da mercadoria.

Para discutirmos essas nossas indagações, tomemos o próprio exemploargumento de Žižek, o dinheiro, aliás, exemplo relevante, pois se trata nada menos que a mercadoria que se fixou como monopólio do equivalente geral.

\subsection{Da forma simples de valor à forma dinheiro: o recalcado do dinheiro ou o enigmático da forma}

Discutimos as determinações de valor de uso, valor e forma de valor da mercadoria, mas ainda precisamos adentrar a sua determinação de fetichismo. 
Acompanhados do sociólogo Paulo Silveira, pensamos que o dinheiro não seja assim genericamente transparente para os sujeitos que dele se utilizam, como afirma Žižek. Silveira (1989) nos alerta para o movimento lógico-histórico que Marx realiza no primeiro capítulo de $O$ capital até chegar ao item final, intitulado "O caráter fetichista da mercadoria e seu segredo".

Marx, imediatamente antes de chegar ao fetichismo da mercadoria, analisa justamente o desdobramento da forma simples de valor até atingir a forma dinheiro. Silveira chama a atenção para o fato de que Marx, ao iniciar a análise da forma simples de valor ( $x$ mercadoria $A=$ y mercadoria $B$ ou 20 varas de linho $=1$ casaco), afirma: "O segredo de toda forma de valor encerra-se nessa forma simples de valor" (MARX apud SILVEIRA, 1989, p. 65). Ou seja, a forma simples de valor é a chave da forma valor. Atentemos para outra consideração de Marx que nos aponta Silveira: "De onde provém, então, o caráter enigmático do produto do trabalho, tão logo ele assume a forma mercadoria? Evidentemente, dessa forma mesmo" (SILVEIRA, 1989, p. 71).

A partir dessas duas afirmações de Marx, podemos perceber a ênfase que ele coloca na forma, aliás, o que ele faz nesse capítulo é uma análise das formas, uma metamorfose das formas. Silveira questiona se o "segredo" da forma valor não seria o mesmo "segredo" do fetichismo (p. 65). Marx indica que o segredo, de qualquer maneira, está na forma, seja na forma simples de valor, seja na forma mercadoria.

Silveira nos faz esses apontamentos ao dizer que a chave desse segredo não se encontra apenas no desenvolvimento da forma simples de valor até atingir a forma dinheiro, mas na forma mercadoria mesma, a qual já na forma simples de valor - por exemplo, o casaco naquela equação - ocupa a posição de equivalente (p. 67). Ou seja, há uma forma mercadoria, o casaco, que já ocupa o lugar de equivalente muito antes da forma dinheiro monopolizar o lugar de equivalente geral. O equivalente já possui o seu lugar na forma de valor menos desenvolvida, a forma simples de valor.

A gênese da forma dinheiro, portanto, nasce com o desenvolvimento da forma simples de valor, na relação de valor entre duas mercadorias, conforme vimos $x$ mercadoria $A=y$ mercadoria $B$ ou 20 varas de linho $=1$ casaco. Essa expressão contém dois polos, sendo que o linho constitui um papel ativo e o casaco um papel passivo, já que o linho expressa o seu valor no casaco. Como apontamos, o valor do 
linho assume um valor relativo, possui a forma relativa, e o casaco possui a forma equivalente nessa equação.

Esses dois polos da expressão são inseparáveis um do outro, pois o linho não tem como se expressar em linho. $E$ isso é o que caracteriza a forma mesma da mercadoria, como apontamos anteriormente em relação ao linho, em que o valor de uma mercadoria só pode ser expresso relativamente, por meio de uma outra mercadoria, senão não há expressão de valor (MARX, 1867, p. 54).

Silveira nos deixa isso claro ao dizer que isso é próprio da forma mercadoria, que não pode expressar o seu valor por si mesma, necessitando que o valor encarne no corpo de outra mercadoria para poder se expressar (SILVEIRA, 1989, p. 68).

Para Marx, o fundamento de que na expressão simples do valor de uma mercadoria encontra-se a relação de valor entre duas mercadorias é exatamente a redução das mercadorias, como grandezas de valor, a uma mesma unidade, a uma mesma qualidade, a coisas de uma mesma natureza: o trabalho abstrato. Por isso, Marx diz: "Linho = casaco é o fundamento da equação" (MARX, 1867, p. 55).

Marx afirma que para expressar o valor do linho como "gelatina de trabalho humano", ele deve ser expresso como uma "objetividade" concretamente diferente do linho mesmo e simultaneamente comum ao linho e a outra mercadoria. O linho vale casaco porque é de mesma natureza, porque é valor. Enquanto coisas de valor são iguais, o casaco compõe-se do mesmo trabalho (abstrato) que o linho. Na relação em que o casaco é o equivalente do linho, a forma do casaco vale como forma de valor. (p. 54). Nesse contexto, retomemos a afirmação de Marx:

\footnotetext{
Por meio da relação de valor, a forma natural da mercadoria $B$ tornase a forma de valor da mercadoria $A$ ou o corpo da mercadoria $B$ o espelho do valor da mercadoria $A$. Ao relacionar-se com a mercadoria B como corpo de valor, como materialização de trabalho humano, a mercadoria A torna o valor de uso de $B$ material de sua própria expressão de valor. $O$ valor da mercadoria $A$, assim expresso no valor de uso da mercadoria $B$, possui a forma do valor relativo. (p. 57)
}

Essa passagem de Marx nos explicita o apontamento de Silveira de que, como equivalente, o valor de uso do casaco se duplica: de um lado, as suas propriedades, o seu valor de uso serve para satisfazer as necessidades humanas, nada de enigmático; de outro lado, no entanto, o valor de uso do casaco, nessa equação, enquanto equivalente, é um corpo que encarna valor, "valor de uso 
puramente social, puramente formal, que decorre de sua função social específica na relação como o linho [...] O seu corpo comum de casaco, na relação, se reveste dessa outra propriedade eminentemente social de exprimir diretamente valor" (SILVEIRA, 1989, p. 69). Esse é um dos aspectos enigmáticos; o próprio valor de uso adquire outra função, além de sua função trivial de satisfazer necessidades: expressar valor.

Dito por nossas palavras, trata-se do fato de o casaco, nessa relação de valor, e repetimos, apenas nela, estar na posição de equivalente que o faz possuir o seu valor de uso duplicado e essa duplicação, por ser o valor que o valor de uso do casaco encarna, delata o seu caráter, como nos diz Silveira, "eminentemente social". Esse é o enigma. Silveira nos diz:

\begin{abstract}
Entretanto muito antes dos homens poderem tomar consciência do fato de que esses resultados emanam de suas próprias relações sociais, já se apagaram os rastros de sua própria história. E Ihes parece, então, que essa lógica pertence à coisa mesma, que resulta, pois, de uma transcendência da coisa em relação aos homens e, o que cabe, portanto, é curvar-se diante dela. (p. 69)
\end{abstract}

Por isso que Marx, segundo Silveira, ao falar da sociabilidade da mercadoria casaco, em sua função de equivalente, também a tomava como "sobrenatural", e isso nos ajuda a entender ao que antes nos referimos sobre a inversão da relação entre coisa e pessoa. Ou seja, que as coisas passam a possuir uma relação fantasmagórica entre si, como se as próprias coisas - mercadorias - ocupassem o lugar dos indivíduos e passassem a se relacionar entre si. O movimento entre coisas escapa ao controle dos indivíduos produtores, os quais ficam submetidos por esse movimento entre as mercadorias:

O misterioso da forma mercadoria consiste, portanto, simplesmente no fato de que ela reflete aos homens características sociais do seu próprio trabalho como características objetivas dos próprios produtos de trabalho, como propriedades naturais sociais dessas coisas e, por isso, também reflete a relação social dos produtores com o trabalho total como uma relação social existente fora deles, entre objetos. Por meio desse quiproquó os produtos do trabalho se tornam mercadorias, coisas físicas metafísicas ou sociais [...] a forma mercadoria e a relação de valor dos produtos de trabalho, na qual ele se representa, não têm que ver absolutamente nada com sua natureza física e com as relações materiais que daí se originam. Não é mais nada que determinada relação social entre os próprios homens que para eles aqui assume a forma fantasmagórica de uma relação entre coisas. (MARX, 1867, p. 71) 
O enigmático do fetichismo faz com que as características do próprio trabalho social dos homens apareçam a eles como características naturais das mercadorias. Dessa forma, a conexão intrínseca entre a relação social dos trabalhadores com o trabalho total desaparece, e essa relação social passa a existir como uma relação apenas entre objetos, entre as próprias mercadorias.

A ilusão misteriosa do fetichismo é uma ilusão inerente à própria produção de mercadorias. A relação de exploração entre os seres humanos é ocultada e aparece como relação entre troca dos produtos de seu trabalho, configurando relações entre coisas (mercadorias), e não relações sociais entre pessoas. Nesse sentido que Silveira nos diz: "Esse caráter sobrenatural não resulta senão do fato de que os homens alienaram na coisa suas próprias relações sociais e, nesse processo, a sociabilidade que thes pertencia e thes pertence é subsumida pela coisa, pela mercadoria, pelo valor, pela forma valor" (SILVEIRA, 1989, p. 69, grifo nosso).

Notemos que, conforme a nota 11 , onde apresentamos a definição que Silveira realiza do conceito de alienação como um processo que em que o sujeito transfere a perda de um poder para o objeto é justamente o que Silveira nos indica aqui: que, sob o fetichismo da mercadoria, os sujeitos transferem o seu poder social, a sua sociabilidade, para as mercadorias e depois a tomam como algo que os transcendem e se curvam a elas.

Até aqui fica difícil concordar com Žižek de que os sujeitos saibam genericamente $^{38}$ da relação social incrustada no fetichismo da mercadoria. Há uma alienação estrutural na forma mercadoria que apaga os rastros de sua história muito antes dos sujeitos poderem saber. $E$ as mediações vão desaparecendo ainda mais quando, na expressão geral de valor, o dinheiro assume o monopólio no lugar de equivalente, como equivalente geral. A duplicação do valor de uso da mercadoria (casaco), que delatava a sua origem de relação social, desaparece, pois o dinheiro possui o exclusivo valor de uso de expressar valor. Sobre isso Silveira diz: "Dissolvem-se, assim, as pegadas que, de certo modo, conectavam materialmente o equivalente ao processo de trabalho e às relações que os homens estabelecem na produção" (SILVEIRA, 1989, p. 70).

${ }^{38}$ Enfatizamos que nossa questão recai sobre a generalização a que consideramos que o filósofo incorre. 
Se, com a duplicação do valor de uso na forma simples de valor, os sujeitos já haviam perdido a consciência da conexão entre o equivalente e as suas próprias relações sociais, agora, com o dinheiro ocupando o lugar de equivalente geral, dissolvem-se ainda mais a conexão do trabalho com as relações sociais no âmbito da produção.

Podemos notar, acompanhando Marx e Silveira, que, com o fetichismo da mercadoria e, portanto, com o fetichismo da mercadoria dinheiro, a alienação vai se redobrando e o processo vai ficando cada vez mais fechado para uma tomada de consciência pelos sujeitos. O resultado é que:

O dinheiro aparece agora como uma figura que pertence
eminentemente ao processo de circulação, portanto, desvinculado
das determinações históricas que lhe deram origem no processo de
produção. Mais do que isso ainda, como uma figura que se apresenta
autonomizada e [...] fetichizada, isto é, à qual se atribui a propriedade
sobrenatural de certificar o valor e a quantidade de valor do produto
das mãos humanas, do trabalho humano. (p. 70$)$

Vejamos esse movimento em Marx para constatarmos como a fantasia, como dissemos, paira sobre a forma mercadoria (dinheiro), que, segundo Silveira, tem os seus rastros apagados, adquirindo poderes mágicos e sobrenaturais.

Estamos tentando mostrar como Marx aplica a determinação da forma de valor da mercadoria ao dinheiro e, assim, desmistifica a forma dinheiro pela compreensão de sua gênese, ao mostrar essa forma como determinação lógicohistórica: o dinheiro constitui o ponto final de um desdobramento lógico e histórico que possui o seu embrião na forma simples de valor, como forma desdobrada da troca simples, portanto, como equivalente geral de todas as mercadorias. Sobre esse desenvolvimento enigmático, Marx diz:

Aqui cabe, no entanto, realizar o que não foi jamais tentado pela
economia burguesa, isto é, comprovar a gênese dessa forma
dinheiro, ou seja, acompanhar o desenvolvimento da expressão do
valor contida na relação de valor das mercadorias, de sua forma mais
simples e sem brilho até a ofuscante forma dinheiro. Com isso
desaparece o enigma do dinheiro. (MARX, 1867, p. 54)

Escutemos que Marx fala que o dinheiro assume uma "ofuscante forma", portanto, para podermos compreender a sua gênese precisamos "acompanhar o desenvolvimento da expressão [simples] do valor", onde se localiza o enigma do 
dinheiro. Marx afirma nessa passagem, ao contrário do que diz Žižek, que o dinheiro não é algo transparente e que, portanto, os sujeitos que dele se utilizam saberiam a sua origem de relação social. Mesmo porque se os sujeitos soubessem, o próprio fetichismo se dissolveria e perderia os seus efeitos fantasmáticos.

Vejamos como a forma mercadoria dinheiro assume o lugar de equivalente geral em seu movimento lógico e histórico, desde a forma simples de valor até a forma geral de valor. O percurso do dinheiro constitui também um percurso histórico e, nesse sentido, algumas de suas determinações são circunstanciais, decorrentes de determinada realidade histórica.

Vamos agora à forma de valor total ou desdobrada, a como se dá a metamorfose da forma simples de valor a essa forma.

\subsubsection{Forma de valor total ou desdobrada}

Marx formaliza a forma de valor desdobrada da seguinte maneira:

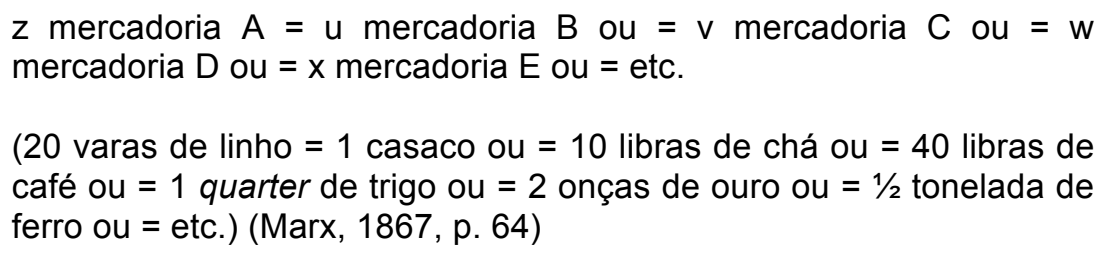

A mudança da forma simples para a forma desdobrada consiste em que o valor de uma mercadoria pode agora ser expresso em qualquer outro corpo de mercadorias, dentro do mundo das mercadorias, o qual se torna espelho de seu valor. Marx afirma que agora o trabalho que gera esse valor de uma mercadoria se equipara a qualquer outro trabalho humano, seja qual for a sua objetivação, se em casaco ou trigo ou ouro ou ferro etc. O linho, portanto, agora se encontra em relação social com o mundo das mercadorias, e não mais apenas com uma outra mercadoria individual, como na forma simples. Essa série interminável do mundo das mercadorias mostra a indiferença da forma do valor de uso na qual o valor mercantil se expressa (p. 64).

Ao falar da forma desdobrada, Marx se refere ao seu movimento lógico, mas também ao seu movimento histórico, na medida em que historicamente as trocas vão se ampliando, deixando de ser ocasionais. Marx afirma que a forma de valor desdobrada surge de fato quando um produto do trabalho, por exemplo, o gado, 
passa a ser trocado habitualmente por várias outras mercadorias, e não mais excepcionalmente (p. 65-66).

Entretanto, o papel do tempo de trabalho, ou seja, a sua grandeza, é que determina a troca: "Desaparece a relação eventual de dois donos individuais de mercadorias. Evidencia-se que não é a troca que regula a grandeza de valor, mas, ao contrário, é a grandeza de valor da mercadoria que regula suas relações de troca" (p.65). Por isso que o valor do linho é o mesmo, seja representado em casaco, ouro ou chá.

$\mathrm{Na}$ forma desdobrada, as inúmeras mercadorias ocupam a posição de equivalente, servindo como corpo de valor do linho. Entretanto, Marx nos diz que essa forma possui as suas insuficiências porque a série interminável de representações da expressão relativa de valor da mercadoria a torna incompleta. $O$ desdobramento seria interminável, de modo que haveria sempre uma nova mercadoria a oferecer-se como material para uma nova expressão de valor. Marx afirma que "As insuficiências da forma relativa de valor desdobrada refletem-se na sua forma equivalente correspondente" (p. 65).

\subsubsection{Forma geral de valor}

Marx afirma que quando alguém troca o linho por outras mercadorias, expressando seu valor em várias outras mercadorias, muitos também, inversamente, trocam suas mercadorias por linho. Marx, portanto, inverte a equação de valor desdobrada, de maneira a obter a equação da forma geral de valor:

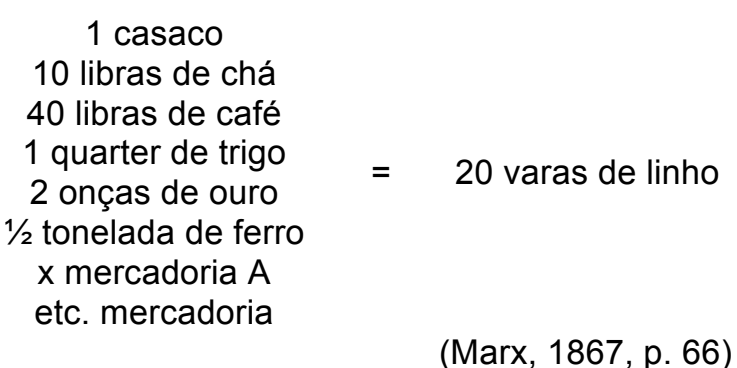

A equação, agora invertida, ${ }^{39}$ já estava contida implicitamente na equação desdobrada, sendo que agora as mercadorias representam seus valores de modo

39 Não se trata de uma inversão simples, na medida em que Marx sempre que inverte acrescenta algo. 
simples e unitário, expressos numa mesma mercadoria isolada das outras, nesse caso, o linho. Segundo Marx, sua "forma valor é simples e comum a todas, portanto, geral" (p. 66).

Essa forma geral, portanto, representa os valores de todas as mercadorias por meio de sua igualdade com o linho. Segundo Marx, essa é a forma que pela primeira vez relaciona as mercadorias entre si como valores, "ou as deixa aparecer reciprocamente como valores de troca" (p. 66). Mas, as mercadorias que adquirem a forma geral do valor também se relacionam entre si como grandezas de valor comparáveis: se 10 libras de chá $=20$ varas de linho, e 40 libras de café $=20$ varas de linho, então, 10 libras de chá = 40 libras de café, o que significa que 1 libra de chá contém o quádruplo de trabalho que contem 1 libra de chá (p. 67).

Mas o mais importante é que a forma geral do valor nessa equação eleva a mercadoria (linho) à categoria de equivalente geral. Conforme Marx, como o linho é agora trocável por todo o mundo de mercadorias, a sua "forma corpórea passa pela encarnação visível, pela crisálida social geral de todo o trabalho humano" (p. 67). A forma geral do valor torna evidente que no mundo das mercadorias "o caráter humano geral do trabalho constitui o seu caráter especificamente social” (p. 67).

\subsubsection{Forma dinheiro}

Iniciamos perguntando como ocorre a transição da forma geral do valor para a forma dinheiro. Bem, para uma mercadoria ocupar o lugar de equivalente geral, ela precisa ser, como vimos, excluída do mundo das mercadorias, e Marx acrescenta que apenas quando:

[...] essa exclusão se limita definitivamente a um gênero específico de mercadorias, a forma valor relativa unitária do mundo das mercadorias adquire consistência objetiva e validade social geral. Então, o gênero específico de mercadoria, com cuja forma natural a forma equivalente se funde socialmente, torna-se mercadoria dinheiro ou funciona como dinheiro. (MARX, 1867, p. 69)

Aqui o caráter histórico da mercadoria que conquista o lugar de equivalente geral mostra a sua força, quando Marx fala do ouro como "determinada mercadoria [que] conquistou historicamente essa posição privilegiada [...]" (p. 69). Dessa forma, para obtermos a forma dinheiro basta substituirmos na fórmula anterior linho por ouro: 
20 varas de linho

1 casaco

10 libras de chá

40 libras de café

1 quarter de trigo

2 onças de ouro

$1 / 2$ tonelada de ferro

$\mathrm{x}$ mercadoria $\mathrm{A}$

etc. mercadoria
$=2$ onças de ouro

(Marx, 1867, p. 69)

Podemos perceber que não houve grandes modificações da forma geral do valor para a forma dinheiro, apenas o fato de que a mercadoria que assume o lugar de equivalente geral não é o linho, mas sim o dinheiro. Sobre isso, Marx nos diz que a fixação do ouro como equivalente geral ocorreu "por meio do hábito social". Ou seja, há uma contingência histórica, e não apenas lógica em todo esse processo.

Interessante retomarmos o que Marx havia afirmado e que ele mesmo retoma nesse ponto: "A expressão relativa simples de valor de uma mercadoria, por exemplo, do linho, na mercadoria que já funciona como mercadoria dinheiro, por exemplo, o ouro, é a forma preço. A 'forma preço' do linho é, pois: 20 varas de linho $=2$ onças de ouro" (p. 69).

Ou seja, que a forma dinheiro encontra o seu germe na forma simples de valor.

\subsection{Fetichismo e inconsciente}

Silveira (1989) considera que a alienação em Marx completa o seu movimento conceitua $^{40}$ com o fetichismo da mercadoria, adquirindo outro sentido, na medida em que passa a ser concebida no contexto da crítica da economia política, adquirindo uma vinculação mais densa com a realidade capitalista. O que há de novo na alienação com a análise do fetichismo da mercadoria, segundo Silveira, é:

[...] a irredutibilidade do fetichismo às formas de consciência e do saber, inclusive as que podem ser consideradas científicas. Essa

40 Silveira analisa o movimento conceitual da alienação partindo dos Manuscritos econômicos-filosóficos, de 1844 (parte final sobre o trabalho alienado), passando por um pequeno excerto dos Grundrisse de 1857/1858, intitulado "O dinheiro como relação social", até chegar ao fetichismo da mercadoria, no fim do primeiro capítulo de $O$ capital. 
irredutibilidade decorre não apenas da necessidade prática que os indivíduos têm de relacionarem os produtos de sua atividade como valores, na troca, mas porque nesta o fetichismo apresenta-se fundido à materialidade mesma que consubstancia a forma mercadoria. (p. 73)

Silveira considera, e concordamos com ele, que o fetichismo da mercadoria e do dinheiro se manifesta conscientemente em muitos indivíduos e em suas práticas, mas ele não afirma isso genericamente, como faz Žižek. Silveira, inclusive, nos alerta para a ilusão a que podemos ser conduzidos se restringimos o fetichismo e as práticas fetichizadas às suas manifestações apenas conscientes pelos indivíduos (p. 74).

Nesse contexto que ele afirma que "estamos todos submetidos ao fetichismo da mercadoria" (p. 74) no capitalismo, apontando que isso significa que o fetichismo não nos atinge externamente, apenas em nossas práticas, mas materializa-se em nosso corpo e psiquismo. A mercadoria força de trabalho, segundo ele, nos mostra bem essa inscrição do fetichismo em nossos corpos e psiques, na medida em que corresponde a disposições e habilidades que envolvem o dispêndio de cérebro, músculos, nervos. Essa inscrição, conforme Silveira, faz com que os sujeitos se determinem naquilo que chama de "basculação dialética entre a coisa - a sua força de trabalho como mercadoria e o correspondente fetichismo - e a pessoa" (p. 74, grifos do autor). Nesse sentido, o fetichismo seria irredutível às formas de consciência, pois instauraria um conflito intrapsíquico que remeteria ao inconsciente.

Silveira faz questão de enfatizar que ele não pensa esse "moldamento da forma mercadoria" no nosso corpo e psiquismo como uma metáfora, mas que:

\footnotetext{
[...] essa forma mesma é que é moldada, no sentido preciso de uma identificação interna do 'sujeito' com a mercadoria, ou seja, como possuidor de um valor de uso e de um valor e que, enquanto tal, mantém-se necessária e permanentemente condicionado à presença de um equivalente, que the autentique como valor e como magnitude de valor. (p. 74)
}

Entretanto, é indispensável dizermos que Silveira rechaça uma posição segundo a qual o fetichismo da mercadoria, na reprodução atual do capitalismo, incidiria de forma totalizante na vida dos indivíduos (p. 76). Ao contrário, o sociólogo afirma uma "tendência do indivíduo a determinar-se como sujeito" (p. 75), que adviria da própria vida, das dimensões recalcadas da vida que retornam e insistem em 
encontrar vias de manifestação (p. 75). Esse apontamento de Silveira rechaça, assim, qualquer posição de resignação diante de uma suposta captura totalizante da alienação fetichista sobre a vida subjetiva e abre para possibilidades de crítica e de ação pelos sujeitos.

Podemos notar que Silveira extrai consequências extremamente relevantes que o fetichismo da mercadoria acarreta para a subjetividade, inclusive para mostrar como a alienação do fetichismo coincide com o lugar do inconsciente. Se os rastros de todo o desenvolvimento, desde a forma simples de valor até a forma dinheiro, foram apagados, o que caracteriza exatamente o que Marx define como o enigmático da forma mercadoria, então os indivíduos que se utilizam da mercadoria dinheiro não têm como acessar essas determinações consciente e genericamente.

Tentamos mostrar, acompanhados por Marx e Silveira, como a expressão da forma simples de valor se desenvolve até a enigmática forma dinheiro, assim como o processo de recalque que as mediações do dinheiro sofrem nessa metamorfose das formas, fazendo desaparecer a conexão existente entre o dinheiro e as suas determinações sociais e históricas, sem deixar rastros.

Trata-se, portanto, de perguntarmos se os sujeitos sabem tanto assim, como afirma Žižek. Ou seja, se não haveria nos sujeitos, sob o fetichismo da forma mercadoria, sob o fetichismo do dinheiro (equivalente geral), um lugar, não apenas em seu ato, mas também em seu pensamento, para um não saber.

Como vimos, Silveira afirma que o fetichismo se manifesta também conscientemente, ou seja, há sujeitos, em determinadas situações, que sabem e fazem, portanto, o cinismo também exerce a sua força. Entretanto, Silveira também considera que o fetichismo estrutura o nosso psiquismo, determinando-nos em termos de um conflito interno/internalizado, naquilo que chamou, como vimos, de uma "báscula dialética". O fetichismo, portanto, não incidiria apenas nas práticas e não se restringiria à consciência, mas nos afetaria do ponto de vista do inconsciente.

Discutíamos no primeiro capítulo que o sintoma nunca é totalmente dissolvido, que, com o atravessamento do gozo e de seu objeto (o objeto a), sempre fica um resto não simbolizável, o sinthoma. Ademais, vimos que o significante também está presente na fantasia e que, na definição do sinthoma, como uma formação significante e de gozo, a dimensão do recalque originário está presente, sempre, quando pensamos em sujeito na psicanálise. O recalque originário, anterior ao sujeito, ao fundar e dividir o psiquismo em lcs e Pcs/Cs, aponta para um saber 
pleno impossível, mesmo no terreno do pensamento, do saber humano. Como vimos, o recalque originário nos mostra a impossibilidade do sujeito de obter um saber completo sobre si mesmo, permanecendo sempre um lugar e um resto onde o sujeito não sabe.

Pensamos que, ao deslocar a ilusão fetichista do plano do saber para o plano do fazer, Žižek acaba por incorrer em uma generalização equivocada, na medida em que tanto por uma constituição do sujeito, quanto por depender das relações sociais em que esteja inserido, o sujeito pode não saber. O fetichismo permaneceria, nesses casos, com a sua parcela de ilusão localizada no próprio saber do sujeito, como Marx nos ensinou.

Dessa maneira, pensamos que a fórmula marxiana do fetichismo da mercadoria, "Não o sabem, mas o fazem", continua atual e operante, dependendo das determinações sócio-simbólicas em que o sujeito se encontra e também dependendo de como o sujeito atua nessas determinações. Afirmamos que o desconhecimento fetichista marxiano pode não operar também de forma genérica, mas pensamos que, ainda assim, continua exercendo a sua força ideológica, não se configurando como um mero desconhecimento ou, como nas palavras de Žižek, "uma espécie de ingenuidade constitutiva básica" (ŽlŽEK, 2007a, p. 312).

Na mesma via de nossa argumentação, também não se trata, inclusive como dizem Marx e Engels em A ideologia alemã, "que na vida comum qualquer shopkeeper sabe muito bem a diferença entre o que alguém faz de conta que é e aquilo que realmente é". Nem sempre se sabe, nem sempre qualquer shopkeeper sabe.

Não concordamos com Žižek, portanto, que os indivíduos, sempre e genericamente, saibam e conheçam a sua atividade social, a sua realidade, como já citamos quando ele diz que os sujeitos "sabem que o dinheiro é uma expressão das relações sociais. Sabem também que por trás das relações entre coisas há as relações entre pessoas". Pensamos que não - muitas vezes os sujeitos simplesmente desconhecem essa realidade.

Esse nosso questionamento aponta para uma possível contradição na própria formulação de Žižek sobre o deslocamento da incidência do fetichismo, na medida em que ele próprio fala em "inconsciente da forma mercadoria" (ŽlŽEK, 2007a, p. 301). Aliás, ao falar da abstração do ato da troca - em que a dimensão social desse ato encontrar-se-ia recalcada - em que haveria uma "Outra Cena, externa ao 
pensamento, mediante a qual a forma do pensamento já é articulada de antemão" (p. 304), o filósofo formula uma possível definição de inconsciente: "a forma de pensamento externa ao próprio pensamento" (p. 304). Žižek também afirma que se os sujeitos no ato da troca, tomados que se encontram pelas mercadorias, viessem a saber demais, esse próprio ato se dissolveria (p. 304-305).

Apesar de Žižek falar em "ato da troca", se levarmos essa afirmação às ultimas consequências, não seria exagerado indagarmos também se esse saber, o qual Žižek apresenta, em alguns momentos, como totalizante e de maneira generalizada no âmbito do pensar dos sujeitos, não dissolveria o próprio fetichismo da mercadoria e, até mesmo, a própria noção de inconsciente.

Como dissemos, de acordo com Silveira, a sujeição a que estamos sob o fetichismo da mercadoria não nos atinge externamente, portanto, não seríamos capazes, por meios voluntários e conscientes, de proteger-nos da incidência do fetichismo. A sujeição ao fetichismo nos determina em nossa constituição social e, portanto, podemos dizer que faz parte da nossa própria estruturação psíquica sob o capitalismo. Podemos pensar, então, que essa dimensão recalcada do dinheiro se inscreve em nosso corpo e em nosso inconsciente, marcando um espaço para um certo índice de ignorância no próprio saber humano por efeito desse processo. 


\section{ALIENAÇÃO, SEPARAÇÃO E IDEOLOGIA}

De certa forma, sucede ao homem como à mercadoria. Pois ele não vem ao mundo nem com um espelho, nem como um filósofo fichtiano: eu sou eu, o homem se espelha primeiro em outro homem. Só por meio da relação com o homem Paulo, como seu semelhante, reconhece-se o homem Pedro a si mesmo como homem. Com isso vale para ele também o Paulo, com pele e cabelos, em sua corporalidade paulínica, como forma de manifestação do gênero humano.

Karl Marx, O capital

Em geral, essas determinações reflexivas são muito peculiares. Esse homem, por exemplo, é rei apenas porque outros homens comportam-se como súditos frente a ele. Eles pensam, ao contrário, que são súditos porque ele é rei.

Karl Marx, O capital

Lacan define em 0 seminário, Livro 11, as duas operações lógicas de causação do sujeito em sua relação dialética com o Outro, a alienação e a separação.

Vejamos o seguinte esquema:

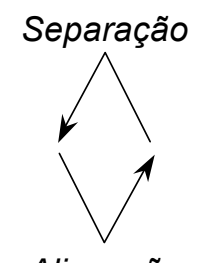

Alienação

(LACAN, 1964, p. 205)

Lacan nos indica o sentido inverso aos ponteiros do relógio, e afirma que o $\mathrm{V}$ da metade inferior do losango constitui a primeira operação, a alienação (LACAN, 1964, p. 205). O 'V' (invertido) da metade superior do losango constitui a segunda operação, a separação (p. 209).

Sobre esse pequeno losango Lacan nos diz:

Aqui os processos devem, certamente, ser articulados como circulares entre o sujeito e o Outro - do sujeito chamado ao Outro, ao sujeito pelo que ele viu a si mesmo aparecer no campo do Outro, do Outro que lá retorna. Esse processo é circular, mas, por sua natureza, sem reciprocidade. Por ser circular, é dissimétrico. (p. 203) 
Nessa passagem, Lacan afirma que os processos que ocorrem (alienação e separação) entre o sujeito e o Outro voltam ao mesmo lugar, e nos indica que ocorrem em um só sentido, sem reciprocidade. Podemos, inicialmente, pontuar nessa passagem um desdobramento temporal desses processos em três momentos: 1.) do sujeito chamado ao Outro; 2.) o que o sujeito vê aparecer no campo do Outro e; 3.) do Outro retornando ao sujeito (TEISSIER, 1994, p. 12). Veremos esses três momentos da inauguração do sujeito mais detalhadamente, ao analisarmos separadamente as operações de alienação e de separação.

\subsection{Alienação}

Para falar dessas duas operações de causação do sujeito, Lacan opera algumas definições dos conceitos de sujeito, significante e Outro. O sujeito depende do significante e o significante está primeiro no campo do Outro (LACAN, 1964, p. 201). Daí, podemos vislumbrar que o sujeito encontra-se na dependência do Outro, mais precisamente, na dependência do significante no campo do Outro.

Lacan define o Outro como "o lugar em que se situa a cadeia do significante que comanda tudo que vai poder presentificar-se do sujeito". (p. 200). Quer dizer, então, que o Outro constitui um lugar, onde sua cadeia significante arraiga a dependência do sujeito ao advir. Lacan diz "tudo". O sujeito encontra-se radicalmente na dependência do Outro, alienado ao Outro, ao menos em seu advento.

O que a alienação nos mostra é que o sujeito só pode se constituir dentro de uma linguagem pré-existente, de uma ordem simbólica que o antecede e já se encontra no campo do Outro. O sujeito - e não o ser vivo - nasce alienado e sujeitado ao significante do Outro.

Retomemos o pequeno losango e imaginemos que do lado esquerdo do losango está o Outro ( $\mathrm{A}$ ) e do lado direito está o sujeito (S). Então, o pequeno ' $\mathrm{V}$ ' inferior da alienação nos mostra esse momento "do sujeito chamado ao Outro" (LACAN, 1964, p. 203), da citação lacaniana acima sobre a circularidade entre o sujeito e o Outro. Momento da condenação ao campo Outro para que o sujeito possa nascer. 
Lacan, para falar da alienação, lança mão da lógica dos conjuntos matemáticos de Euler e introduz a forma lógica da reunião, vel dessa primeira operação que funda essencialmente o sujeito:

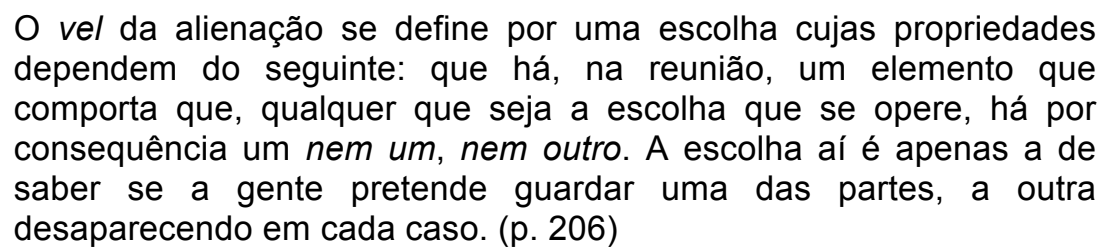

Essa afirmação de Lacan ganha sentido quando depois ele afirma que há na alienação um "não há algo [...] sem outra coisa" (p. 212); no caso da dialética do escravo "não há liberdade sem a vida" (p. 212). Há na operação de alienação uma condição necessária entre ambas as escolhas que é a razão suficiente que causa a perda original. Trata-se de uma divisão fundamental que institui a dialética do sujeito, não havendo como escapar disso, só podendo haver sujeito quando há também o seu desaparecimento. (p. 216).

Essa consideração sobre a perda original é de extrema relevância, porque Lacan fala, em Posição do inconsciente (1960/1964) que o que qualifica a alienação não é a sua operação de se iniciar no Outro - isso só explicaria porque nenhum sujeito pode ser causa de si mesmo. Há, para Lacan, uma prioridade e uma anterioridade do significante em relação ao sujeito. O que qualifica a alienação é a sua operação que reside na divisão do sujeito (LACAN, 1960/1964, p. 855). Notemos aqui que essa definição coincide com a de recalque originário.

A alienação, portanto, consiste na constituição do sujeito a partir do Outro e na sua inescapável divisão. O esquema lacaniano do pequeno losango, após a operação de alienação e a resultante divisão do sujeito, poderia ser assim ilustrado:

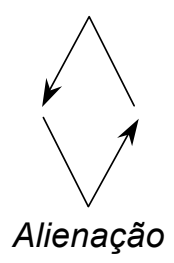

A operação de alienação vai do Outro pleno $(A)$, sem barra, produzindo um sujeito dividido, onde Lacan colocou uma barra, o sujeito barrado (\$). 
Lacan nos fornece alguns exemplos dessa escolha forçada, desse "ou alienante": "A bolsa ou a vida!". Se escolhermos a bolsa, perdemos as duas. Se escolhermos a vida, tê-la-emos decepada da bolsa (LACAN, 1964, p. 207). Notemos que nesse caso só é possível escolher um dos termos da oração. Lacan nos fala sobre isso em Posição do inconsciente:

\footnotetext{
Essa reunião é tal que o vel que dizemos de alienação só impõe uma escolha entre seus termos ao eliminar um deles, sempre o mesmo, seja qual for essa escolha. O que está em jogo limita-se, pois, aparentemente, à conservação ou não do outro termo, quando a reunião é binária. (LACAN, 1960/1964, p. 855)
}

Lacan explicita ter buscado em Hegel a justificação do vel alienante, o engendramento da primeira alienação, "aquela pela qual o homem entra na via da escravidão, 'A liberdade ou a vida!" (LACAN, 1964, p. 207). Se a escolha é a liberdade, perde-se as duas. Se a escolha é a vida, esta será amputada da liberdade. A única possibilidade de liberdade é escolher a morte, pois haveria a liberdade de escolha. (LACAN, 1964, p. 207-208).

Para ilustrar a alienação, pela forma lógica do vel da reunião, Lacan introduz no vel alienante o ser do sujeito, o qual se encontra sob o sentido. Lacan afirma que se a escolha é o ser, o sujeito desaparece, escapa ao não-sentido. Se a escolha é pelo sentido, esse só existe amputado dessa parte do não-senso, que, para Lacan, é o inconsciente:

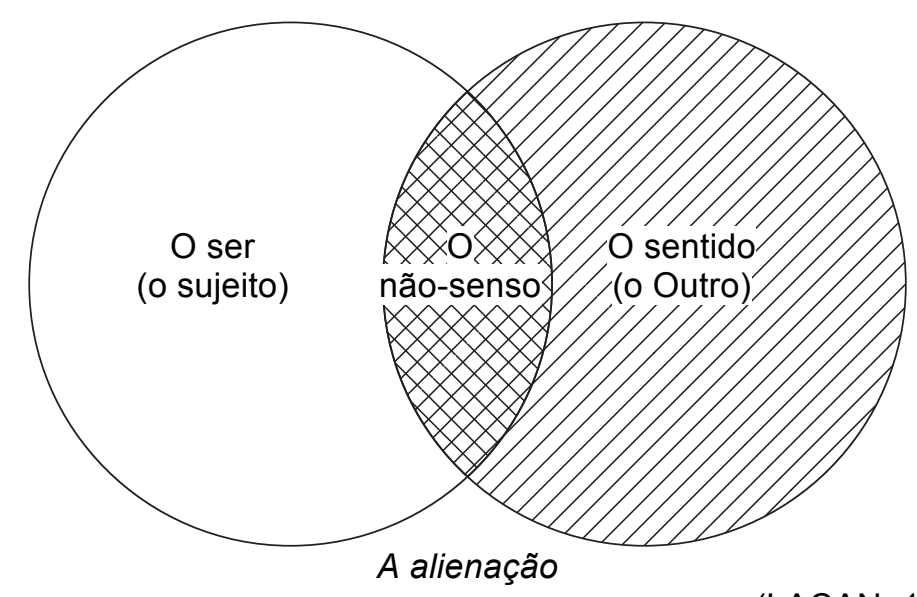

(LACAN, 1964, p. 206-07)

A alienação envolve essa escolha forçada pelo sentido, acarretando sempre numa perda, num sem-sentido, que é o inconsciente. Sobre essa operação alienante 
de, por um lado, escolher pelo sentido, e, por outro lado, necessariamente haver uma perda, um sem-sentido, nos diz Lacan:

\begin{abstract}
Do mesmo modo, nosso sujeito é colocado no vel de um sentido a ser recebido ou da petrificação. Mas, se ele preserva o sentido, é esse campo (do sentido) que será mordido pelo não-sentido que se produz por sua mudança em significante. E é justamente do campo do Outro que provém esse não-sentido, apesar de produzido como eclipse do sujeito. (LACAN, 1960/1964, p. 855-6)
\end{abstract}

Se a escolha não for pelo sentido (e a sua consequente amputação do ser, o seu desaparecimento ou a sua afânise), haverá petrificação do sujeito. Soler nos fala que ou há petrificação ou há sentido. O sujeito petrificado por um significante é um sujeito que não se questiona sobre si, que apenas vive e age, mas jamais pensa sobre si, sobre o que é. O analisante é o sujeito que escolheu pelo sentido, pelo infinito deslizar do sentido (SOLER, 1997b, p. 61-62).

Lacan introduz outro exemplo, de uma ordem diferente, para evidenciar, conforme Hegel, o essencial do vel alienante, o seu fator letal: "a liberdade ou a morte!" (LACAN, 1964, p. 208). Algo aqui muda um pouco, pois se a escolha recai sobre a liberdade, ter-se-á a liberdade de morrer:

\begin{abstract}
A liberdade, vocês sabem, antes de mais nada, é como a famosa liberdade do trabalho, pela qual a revolução francesa, parece, se bateu - pode bem ser também a liberdade de morrer de fome, é mesmo ao que isso levou durante todo o século dezenove, é por isso que foi preciso depois, revisar alguns princípios. Vocês escolhem a liberdade, muito bem!, é a liberdade de morrer. (p. 208).
\end{abstract}

Interessante notarmos que a noção de liberdade que Lacan apresenta nessa passagem é muito semelhante à noção marxiana de liberdade, ou seja, a liberdade definida pela sua negatividade. Há uma inversão, melhor dizendo, uma subversão dessa definição. Para Marx, a liberdade é a liberdade que o trabalhador possui de vender a sua força de trabalho, portanto não é uma liberdade.

\title{
4.2 Separação (em oposição à alienação)
}

Lacan introduz o termo separação em Formulações sobre a causalidade psíquica (1946), mas apenas em O seminário, Livro 11 (1964), ele especifica a 
alienação e a separação como as operações fundamentais de causação do sujeito (TEISSIER, 1994, p. 10).

Em Posição do inconsciente, Lacan fala da separação como a "segunda operação, onde se fecha a causação do sujeito" (LACAN, 1964, p. 856). Com isso, retomamos e reafirmamos que, na alienação e na separação, os processos que ocorrem entre o sujeito e o Outro são circulares, isto é, voltam ao mesmo lugar, sem haver reciprocidade, e a separação fecha o círculo de causação do sujeito.

Voltemos novamente ao esquema do pequeno losango para visualizar agora a operação de separação, que fecha a circularidade de causação do sujeito:

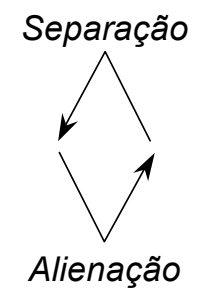

(LACAN, 1964, p. 205)

Se considerarmos $O$ ' $V$ ' invertido, superior do losango, e imaginarmos novamente o Outro (A) do lado esquerdo e o sujeito (S) do lado direito, então, naquela mesma citação de Lacan, podemos localizar na separação o terceiro momento do desdobramento temporal, momento em que Lacan fala "do Outro que lá retorna". (p. 203). Ou seja, o momento em que o Outro retorna ao sujeito. Com essa operação de separação, o Outro $(A)$ passa a ser o Outro barrado $(A)$, um outro Outro. O esquema do losango, então, poderia ficar assim:

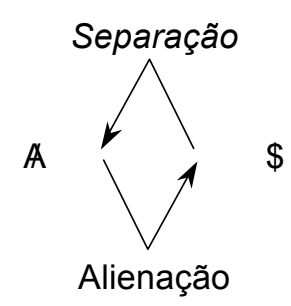

O vetor da operação de separação, posterior ao da alienação, vai do sujeito barrado $(\$)$ ao Outro barrado $(A)$. Como podemos ver, a alienação opera a divisão do sujeito, e a separação opera a "barração" do Outro. Com essas operações, o sujeito e o Outro recebem uma barra. 
Soler nos indica que a separação é introduzida por Lacan sob a forma lógica da intersecção, em que ocorre o isolamento daquilo ou parte daquilo que pertence a ambos os conjuntos (SOLER, 1997b, p. 59).

Entretanto, Lacan modifica a operação da intersecção para definir a separação. A separação constitui uma intersecção definida por aquilo que falta a ambos os conjuntos, não pelo que pertence aos dois (SOLER, 1997b, p. 61). Na separação, que "conclui a circularidade da relação do sujeito com o Outro, nos furos de seu discurso" (TEISSIER, 1994, p. 10), a intersecção é efeito do recobrimento das duas faltas. O elemento comum é a falta.

Soler afirma que a grande novidade do livro 11 de 0 seminário é o que se introduz no campo do sujeito com a separação:

\begin{abstract}
A alienação é o destino. Nenhum sujeito falante pode evitar a alienação. É um destino ligado à fala. Mas a separação não é destino. A separação é algo que pode ou não estar presente, e aqui Lacan evoca um velle, em francês vouloir, em inglês a want, um querer. Isso é muito semelhante a uma ação pelo sujeito. [...] A separação requer que o sujeito "queira" se separar da cadeia significante [...] A separação supõe um vontade de sair, uma vontade de saber o que se é para além daquilo que o Outro possa dizer, para além daquilo inscrito no Outro. (SOLER, 1997b, p. 62-63, grifos nossos)
\end{abstract}

A partir dessa passagem de Soler, enfatizamos a posição de atividade e de desejo do sujeito, a posição de sujeito desejante na separação em contraposição a sua inescapável posição de passividade e de destino na alienação.

A dimensão do desejo é a condição que possibilita a separação. Lacan, em Posição do inconsciente, nos aponta que o intervalo (entre S1 - S2...) do discurso do Outro é o lugar veículo do desejo (LACAN, 1964, p. 858). E isso Lacan também nos mostra no livro 11 de $O$ seminário, ao dizer que a intersecção surge do recobrimento das duas faltas, que reúne a falta do discurso do Outro e a falta que precede o próprio desaparecimento do sujeito. Vejamos isso melhor.

A falta encontrada pelo sujeito no Outro é a intimação pelo discurso desse Outro. Nos intervalos do discurso do Outro, o pequeno sujeito pergunta: "ele me diz isso, mas o que é que ele quer?"41 (LACAN, 1964, p. 209). O sujeito apreende o desejo do Outro nas faltas de seu discurso, cortando os significantes, lá onde:

41 "Che vuoi?". 
[...] foge como o furão, o que chamamos desejo. O desejo do Outro é apreendido pelo sujeito naquilo que não cola, nas faltas do discurso do Outro, e todos os por-quês? da criança testemunham menos de uma avidez da razão das coisas do que constituem uma colocação em prova do adulto, um por que será que você me diz isso? sempre re-suscitado de seu fundo, que é o enigma do desejo do adulto. (p. 209)

$\mathrm{Na}$ intersecção entre o sujeito e o Outro há, portanto, uma falta, uma lacuna que Lacan denomina de desejo, que, para além do que se diz, fica sempre a questão do que se quer. Além dos significantes do Outro, há sempre um " $x$ " no Outro, um enigma sobre o que quer, sobre qual o seu desejo. Portanto, para Lacan, é mais o enigma sobre o desejo do Outro que move os por quês da criança, e não tanto a sua capacidade racional.

Soler diz que é por isso que o desejo aparece necessariamente na fala, pois há uma impossibilidade na fala de dizer o que se quer devido a sua própria constituição. Na fala há a dimensão do enunciado, daquilo que se declara, e há a dimensão da enunciação, que, para além do que se declara, há a questão de onde se quer chegar, do que se quer com o que se declara. A fala necessariamente faz surgir o enigma sobre o desejo do Outro (SOLER, 1997b, p. 63).

Diante da falta percebida no Outro e de seu enigma, o sujeito responderia com a falta antecedente de seu próprio desaparecimento. O primeiro objeto que ele propõe a esse desejo parental, cujo objeto é desconhecido, é sua própria perda "Pode ele me perder?" (LACAN, 1964, p. 210). Trata-se da fantasia infantil da própria morte ou de desaparecimento, que são amenizadas pela criança em sua relação de amor com seus pais. Lacan dá o exemplo da anorexia, em que se responde à demanda da mãe não se alimentando para alimentá-la, numa tentativa radical de fazer falta no Outro materno (p. 210).

Sobre essa segunda falta, Soler afirma que, para que a separação ocorra, é preciso a condição do encontro com a falta do desejo. O que está presente na intersecção da separação é tanto a falta do desejo, a falta do Outro, quanto o ser perdido do sujeito (SOLER, 1997b, p. 64).

O elemento comum na separação é a falta, o ponto de intersecção do desejo do sujeito com o desejo do Outro, onde, segundo Lacan, "uma falta recobre a outra" (LACAN, 1964, p. 210). 


\subsection{Separação, alienação e objeto a}

Como vimos, o Outro da separação é diferente do Outro da alienação. Não é o Outro pleno de significantes (que Lacan escreveu como "A"), mas o Outro faltoso, que Lacan escreveu cortado por uma barra (A "barrado") (SOLER, 1997b, p. 63).

Em relação ao Outro, na separação a questão do sujeito é: "o que sou eu no desejo do Outro?" (SOLER, 1997b, p. 65). A lacuna existente na interseç̧ão ou no intervalo entre o sujeito e o Outro, segundo Soler, não é tão vazia como se pode pensar, alguma coisa entra:

\footnotetext{
É o objeto a, na medida em que o objeto a não é sempre de ordem lógica, mas tem também uma consistência corpórea, e também na medida em que o objeto a é um plus de jouir, como diz Lacan: um gozo a mais. (SOLER, 1997b, p. 65)
}

Notemos, conforme Soler, que a separação leva Lacan a dar um passo adiante na sua tese do inconsciente estruturado como uma linguagem, na medida em que a fala e o gozo são articulados com a separação. E é aí que se localiza, conforme ela, "a resposta para a questão inefável do sujeito" (p. 65). O sujeito para além do significante é sujeito do gozo. O gozo possui o seu real no objeto $a$, portanto, o que está em jogo com a separação é o objeto $a$.

Voltemos à tese de Žižek de que a ideologia é uma fantasia, em sua dimensão real e inconsciente, que estrutura a realidade social (ŽIŽEK, 1992, p. 61). Ou seja, a própria realidade social é atravessada por uma dimensão fantasmática, pela intromissão de um gozo que irrompe no campo social.

No contexto de uma leitura política do gráfico lacaniano do desejo, em que discute a ideologia, mais especificamente, o antissemitismo, Žižek considera que a fantasia constitui uma construção imaginária para tentar preencher o vazio deixado pelo "Che vuoi?". Diante dessa pergunta introduzida, como vimos, com a separação, a fantasia surgiria como uma tentativa de silenciar essa pergunta, ou melhor, de elidir o seu efeito, a falta cavada pelo enigma do desejo do Outro, na medida em que escaparíamos ao insuportável de nos deparar com a questão sobre o que o Outro quer de nós, portanto, com a nossa própria falta. A fantasia seria uma resposta à angústia provocada pelo enigma do desejo do Outro que não encontra simbolização, já que haveria a intromissão do gozo (p. 112-113). Podemos afirmar que a fantasia 
(ideológica) realizaria, portanto, um fechamento da abertura realizada pela separação.

Entretanto, é justamente na tentativa de preencher essa falta do Outro (ordem simbólica como uma totalidade coerente e fechada) que podemos nos deparar com nosso desejo, que aprendemos a desejar. Recordemos como a separação, ao introduzir o objeto a, faz com que nos deparemos com o desejo. Segundo Žižek, esse é o paradoxo da fantasia, que sustenta e organiza o desejo e, ao mesmo tempo, funciona como uma defesa. O filósofo propõe que levemos esse paradoxo mais além para compreendermos Lacan, ao dizer que o próprio desejo, estruturado pela fantasia, constitui uma defesa contra o desejo do Outro, uma forma de tapar o desejo do Outro (p. 116;163).

A conhecida afirmação de Lacan "não ceder em seu desejo" ganha sentido e coincide, em termos de um processo analítico, com o momento de um "fim de análise", de travessia da fantasia, quando a transferência se dissolveria, e o analisante não precisaria mais se oferecer como objeto de amor do analista, renunciando, dessa forma, a preencher a falta do Outro (p. 116).

Esse momento da travessia da fantasia, segundo Žižek, coincide também com a formulação lacaniana da identificação com o sinthoma, o qual brevemente apresentamos no primeiro capítulo, uma formação significante penetrada pelo gozo, a junção impossível de gozo e significante (p. 120-121). Nesse sentido, a fantasia mascararia o fato de que o Outro se estrutura como uma impossibilidade traumática que não encontra vias de simbolização, que é o que Lacan teria chamado de "real do gozo" (p. 121).

Laurent, assim como Soler, enfatiza o sujeito para além do significante, como sujeito de gozo, ao dizer que a alienação encobre ou negligencia o fato de que o sujeito se define tanto na cadeia significante quanto no nível das pulsões, pelo seu gozo em relação ao Outro (LAURENT, 1997b, p. 43).

Laurent nos apresenta os esquemas desenvolvidos por Miller para as operações de alienação e de separação que nos permite diferenciá-las melhor: 
Esquema 1

Alienação
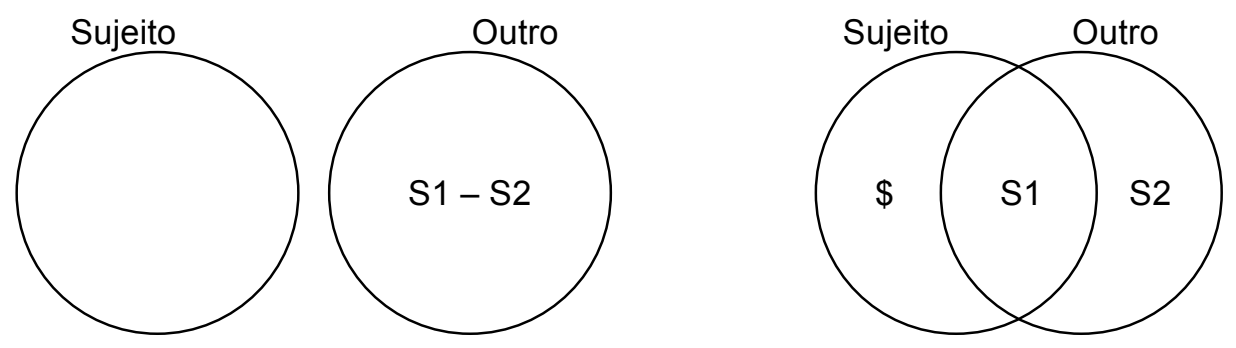

Esquema 2

Separação

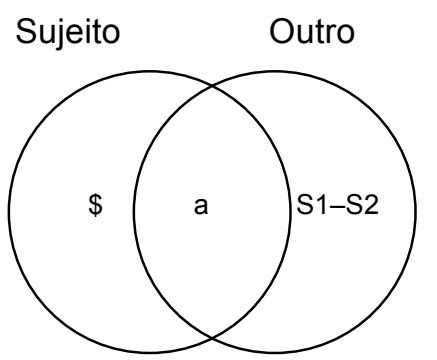

(LAURENT, 1997, p. 43)

A primeira ilustração do esquema 1 mostra que, inicialmente, não há sujeito, há um conjunto vazio, há um ser vivo, pois o sujeito apenas nasce a partir dos significantes do Outro que lhe causam:

O sujeito não é uma substância: o sujeito é um efeito do significante. O sujeito é representado por um significante, e antes do surgimento do significante (S1) não existe sujeito. Mas o fato de não existir sujeito não quer dizer que não exista nada, porque pode existir um ser vivo, mas este ser vivo se torna um sujeito somente quando um significante o representa. Logo, antes do surgimento do significante, o sujeito é nada. (SOLER, 1997a, p. 56)

O momento em que ocorre a operação de alienação (segunda ilustração do esquema 1), que barra/divide o sujeito, é o momento mesmo em que esse surge como sujeito do inconsciente. Conforme anunciamos, é o momento que coincide com o recalque originário. A alienação divide e funda o sujeito, na medida em que o que era vazio agora passa a se constituir pela cadeia S1-S2 do Outro.

$\mathrm{Na}$ lacuna entre o sujeito e o Outro, como citamos em Soler, alguma coisa entra, o objeto a, objeto causa do desejo. No livro 11 d'O seminário, o objeto a surge como efeito da lacuna entre o sujeito e o Outro na operação da separação. Isto significa que o que produz o objeto a é a operação de separação. 
É nessa primeira dupla significante (S1-S2), de onde Lacan deduziu a operação de alienação do sujeito e onde, no intervalo dessa dupla, a separação opera a partir da falta no Outro. Entretanto, para o psicanalista, a alienação não é uma operação que funda o sujeito e depois cessa. A alienação é uma operação interminável, que tanto funda e estrutura o sujeito no ponto em que coincide com o recalque originário quanto continua a operar incessantemente ao longo de sua vida psíquica. Sobre esse nosso entendimento citamos uma passagem de Lacan que aponta para isso:

\begin{abstract}
O desejo do homem é o desejo do Outro. Será que não há, reproduzido aqui, o elemento de alienação que lhes designei no fundamento do sujeito como tal? [...] a experiência analítica nos mostra que é de ver funcionar toda uma cadeia no nível do desejo do Outro que o desejo do sujeito se constitui [...] Na relação do desejo ao desejo, algo é conservado da alienação, mas não com os mesmos elementos - não com esse $S 1$ e esse $S 2$ da primeira dupla significante, de onde deduzi a fórmula da alienação do sujeito [...] mas de uma parte, com o que é constituído a partir do recalque originário, da queda, do Unterdrückung, do significante binário - e, de outra parte, com o que aparece primeiro como falta no que é significado pela dupla de significantes, no intervalo que os liga, isto é, o desejo do Outro. [LACAN, 1964, p. 229, grifo nosso]
\end{abstract}

Nessa passagem Lacan afirma que "algo é conservado da alienação", algo diferente da primeira dupla de significantes (S1-S2) que funda e divide o sujeito. Esse algo é uma parte que resta da operação do recalque originário do significante binário (representante da representação) e outra parte que resta do desejo do sujeito ou o desejo do Outro. Lacan mesmo afirma nessa citação que o desejo do sujeito é o desejo do Outro.

O que se conserva da alienação são restos: restos do recalque originário e do desejo. Podemos pensar aqui que esses restos nos remetem para uma questão que estamos o tempo todo discutindo nesta pesquisa, a de haver sempre, inescapavelmente, um resto que o sujeito não sabe e a que se mantém alienado como diz Lacan, onde "algo é conservado da alienação" - que coincide com o recalque originário. Haverá sempre um saber não todo no sujeito, o qual nunca saberá plenamente sobre si mesmo. Mas há também a separação, a abertura que o objeto a possibilita para o sujeito se "liberar", em certa medida, da alienação ao Outro. 
Sobre a ligação entre a separação e o objeto a, Lacan aponta para uma outra função que o processo de separação introduz:

\begin{abstract}
Trata-se desse objeto privilegiado, descoberta da análise, desse objeto cuja realidade mesma é puramente topológica, desse objeto do qual a pulsão faz o contorno, desse objeto que faz bossa, como o ovo de madeira no tecido que vocês estão, na análise para retomar - o objeto a. [...] Pela função do objeto $a$, o sujeito se separa, deixa de estar ligado à vacilação do ser, ao sentido que constitui o essencial da alienação. (LACAN, 1964, p. 249)
\end{abstract}

Essa passagem agora nos é palatável, na medida em que estudamos as operações de alienação e separação. Lacan define, nesse contexto, o objeto a como um objeto contornado pela pulsão e que consiste numa "função", introduzida com a operação de separação. E mais ainda, Lacan, nessa passagem, contrapõe a separação à alienação, ao dizer que é a partir da separação que o sujeito pode "livrar-se" ${ }^{42}$ do essencial da alienação que é o sentido.

Na tese de Žižek sobre a ideologia estar estruturada como real da fantasia e não mais como sintoma, a fantasia ideológica nos direciona à compreensão na sua dimensão de gozo, de sem-sentido, daquilo que nos escapa o tempo todo por não ter sido ainda simbolizado, um excesso constitutivo que, como diz Lacan, "não cessa de não se escrever". Conforme vimos na citação de Soler, um "plus de jouir", "um gozo a mais".

Žižek nos convoca, portanto, a ir além da ideologia como um discurso de significação ou de seu efeito afanisíaco de sentido, a ir além da leitura da ideologia como um sintoma que demandaria uma interpretação em termos de seu deciframento. O filósofo pensa a ideologia além do simbólico e do imaginário, ou seja, em termos do real, "da pulsão que vibra em torno de um insustentável maisgozar" (ŽIŽEK, 1992, p. 121).

Em sua distinção milleriana entre sintoma e fantasia, que discutimos no primeiro capítulo, o filósofo extrai da ideologia o seu núcleo sem sentido, o excesso que constitui o seu esteio. Para além do campo da significação do sintoma, o filósofo nos leva para a concepção da ideologia sustentada em um gozo e em seu objeto, o

${ }^{42}$ Expressão nossa, com todas as ressalvas. 
objeto a, estruturado na fantasia (p. 122). Daí ele falar em real da fantasia, referindose ao núcleo de gozo da fantasia.

Žižek, baseado em Lacan, toma a separação em contraposição à alienação e como a operação que torna possível ao sujeito se livrar do efeito afanisíaco do sentido:

\begin{abstract}
Lacan, pelo contrário, admite uma autonomia subjetiva muito maior: na medida em que o sujeito ocupa o lugar da falta no Outro (ordem simbólica), pode realizar a separação (operação que é o oposto da alienação), e suspender o reino do grande Outro, isto é, separar-se dele. (Žižek, 2004, p. 70) ${ }^{43}$
\end{abstract}

A separação constitui essa suspensão do reino do grande Outro pelo sujeito quando este assume a falta na ordem simbólica, o que abre uma margem de "liberdade" ou, como Žižek diz, uma "autonomia subjetiva". Essa autonomia corresponde a essa abertura entre o sujeito e o Outro, onde entra o desejo e o objeto de sua causa, o objeto $a$.

Recordemos aqui a noção de identificação ao sinthoma perpassado pelo gozo, quando Dunker fala da dimensão disruptiva e separadora que o sintoma também possui (para além da identificação ao sintoma familiar, geracional), na medida em que a identificação também recai sobre um traço de gozo, o objeto a, que singulariza o sujeito desejante. O objeto $a$, introduzido pela operação de separação, possibilitaria ao sujeito criar algum espaço para o seu próprio desejo, algum espaço que não seja de um desejo totalmente alienado ao Outro.

Indagamo-nos em que medida, a partir da noção de separação e de objeto a lacaniano, poderíamos pensar em algum espaço possível de crítica da ideologia, sem afirmar com isso que estaríamos, assim, completamente fora da ideologia ou num suposto espaço de neutralidade.

Afinal de contas, se partirmos da operação de alienação do sujeito ou da alienação social (em termos da sua leitura sintomal), recaímos necessariamente na ideologia, já que voltamos ao efeito afanisíaco do sentido, que fecha o furo constitutivo da ordem simbólica e o seu efeito, o real. O real lacaniano é o efeito do

43 Tradução nossa para: "Lacan, por el contrario, admite una autonomía subjetiva mucho mayor: en la medida en que el sujeto ocupa el lugar de la falta en el Otro (orden simbólico), puede realizar la separación (operación que es el opuesto de la alienación), e suspender el reino del gran Otro, es decir, separarse de él". 
furo que o simbólico faz na realidade, o efeito de uma fissura constitutiva do simbólico, pois a simbolização, como vimos, sempre falha em alguma medida.

Por isso que apontamos a margem de autonomia do sujeito na separação, pois é essa operação que abre para o furo do simbólico, para o sem sentido do gozo e para o objeto a, causa do desejo. A separação, portanto, abre para o sujeito certa margem de liberdade de agir. Retornemos aqui às nossas considerações e grifos de uma citação anterior de Soler, em que discutíamos sobre a posição de atividade e de desejo que o sujeito ocupa na separação em oposição a sua posição passiva, de destino, na alienação. A separação requer uma "ação", um "querer", uma "vontade de sair" por parte do sujeito.

Entretanto, é preciso salientar que essa "ação" por parte do sujeito não constitui uma ação voluntária e restrita ao plano da consciência, pois, se assim o fosse, recairíamos no sujeito da consciência, que saberia plenamente sobre o seu agir, sobre as motivações de seu agir etc.. Trata-se, conforme já dissemos, do sujeito psicanalítico, dividido pelo recalque originário que o funda, portanto, do sujeito determinado pelo inconsciente que o constitui e a quem a operação de separação possibilita a abertura de um furo para o sem sentido, furo que poderia constituir um ponto de partida de uma possível crítica da ideologia, ainda que determinada por processos inconscientes.

Relembremos também a discussão de Silveira que apresentamos anteriormente sobre a irredutibilidade da alienação do fetichismo da mercadoria às formas de consciência e a ilusão a que podemos ser conduzidos se a restringirmos a uma manifestação da consciência. A sujeição a que estamos sob o fetichismo da mercadoria, por nos estruturar psíquica e socialmente, não permite nos protegermos da incidência do fetichismo por meios voluntários e conscientes. A possibilidade de alguma crítica da ideologia, portanto, não estaria livre das determinações do inconsciente e, conforme vimos, poderia vir de um encontro da abertura possibilitada pela operação de separação com as dimensões recalcadas da vida que insistem em encontrar vias de manifestação. 


\subsection{Alienação, separação e fetichismo}

Retomemos agora a figura lacaniana das operações de causação do sujeito, alienação e separação, com o objetivo de discutir a influência recíproca entre essas operações e a ideologia como alienação fetichista:

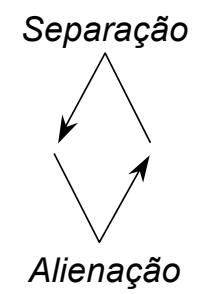

De acordo com o pequeno losango, podemos constatar que o ' $V$ ' inferior e o invertido superior não são contíguos, não se tocam, pois pertencem a planos diferentes. No plano da alienação ocorre um fechamento imaginário, que Marx expressa em sua análise da relação de valor. Retomemos a forma embrionária do valor, a forma simples de valor:

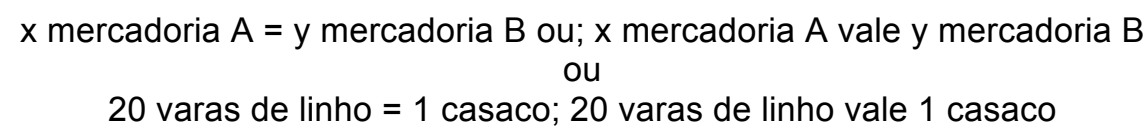

(MARX, 1867, p.54)

Lembremos aqui como vimos ser próprio da mercadoria não conseguir expressar o seu valor por si mesma, ou seja, o linho não pode se expressar em linho - linho = linho não constitui uma expressão de valor. Uma mercadoria necessita do corpo de outra mercadoria para seu valor encarnar. No caso da expressão acima, o valor da mercadoria linho necessita do corpo da mercadoria casaco, o qual encarna e, consequentemente, expressa especularmente o seu valor.

Marx nos diz ainda que o mesmo ocorre com o homem, que necessita refletirse no corpo de outro homem para se ver e se reconhecer como homem. É a imagem espelhada que um homem devolve ao outro que faz com eles se reconheçam como homens, determinando-se mutuamente. Sobre isso Žižek nos diz que Marx teria antecipado a teoria lacaniana do estádio do espelho, na medida em que apenas quando um ser humano oferece ao outro uma imagem de sua unidade que o eu (moi) alcança a sua autoidentidade. Dessa forma, para Žižek, haveria uma correlação estrita entre identidade e alienação (ŽIŽEK, 2007a, p. 309). 
Tomemos aqui a definição lacaniana de alienação que vimos e que nos mostra que o sujeito apenas advém dentro de uma ordem simbólica pré-existente, portanto nasce alienado ao significante do Outro. O sujeito apenas advém como sujeito ao alienar-se ao Outro, não tendo como tornar-se sujeito por si mesmo ou como causa de si mesmo. Não se trata aqui de tentarmos igualar epistemologicamente os conceitos de alienação estrutural do sujeito em Lacan e de alienação da mercadoria em Marx, mesmo porque, conforme vimos com Lacan em Posição do inconsciente, o que qualifica a alienação, mais do que a dependência arraigada da origem do sujeito ao Outro, é a divisão do sujeito, coincidente com o recalque originário, operações estritamente psicanalíticas. Entretanto, isso não nos impede nesta pesquisa de abarcar um enlace psicossocial entre esses modos de alienação e as suas mútuas influências.

Retomemos também a noção lacaniana de separação, que, conforme vimos, é a operação que possibilita um intervalo entre o sujeito e o Outro, constituindo certa suspensão do reino do Outro pelo sujeito e abrindo uma margem de autonomia subjetiva. Essa autonomia corresponde, como vimos, a essa abertura que a operação de separação produz, que permite ao sujeito criar algum espaço singular para o seu desejo, que não esteja totalmente alienado ao Outro.

Ainda em tempo, fazemos a consideração aqui de que a crítica da ideologia conforme a concepção da ideologia enquanto alienação do fetichismo da mercadoria - pode acarretar num fechamento da totalidade social, que é o que grande parte das críticas, principalmente as lacanianas, dirige a essa concepção de Marx - e é também o que Žižek pensa quando ele diz que:

\footnotetext{
[...] na perspectiva marxista predominante, o olhar ideológico é um olhar parcial, que deixa escapar a totalidade das relações sociais, ao passo que, na perspectiva lacaniana, a ideologia designa, antes, a totalidade empenhada em apagar os vestígios de sua própria impossibilidade. (ŽIŽEK, 2007a, p. 327)
}

Embora essa crítica seja bastante considerável por questionar uma suposta totalidade - por vezes tomada como uma totalidade fechada - na noção de fetichismo da mercadoria, ela não nos dispensa de levar em consideração a complexidade dos efeitos inconscientes a que estamos submetidos sob o fetichismo da mercadoria, conforme discutimos no capítulo anterior. 
Além do mais, com o fetichismo da mercadoria não se trata simplesmente de uma total des-alienação da consciência alienada, como Marx e Engels afirmam em $A$ ideologia alemã. Não apenas porque sob a alienação do fetichismo da mercadoria o que está em jogo é o inconsciente - e não a consciência como em $A$ ideologia alemã -, mas também porque, em se tratando do inconsciente, há algo da alienação estrutural que se conserva e que, após fundar e dividir o sujeito, não cessa de se repetir ao longo de sua vida psíquica, numa operação interminável, conforme vimos com Lacan.

Žižek, quando faz essa afirmação da citação acima, diz que essa diferença ideológica corresponde à diferença entre fetichismo em Marx e Freud, sendo que "no marxismo, o fetiche oculta a rede positiva de relações sociais, ao passo que, em Freud, o fetiche oculta a falta ('castração') em torno da qual se articula a rede simbólica" (ŽlŽEK, 2007a, p. 327).

Vejamos isso no texto Fetichismo (1927), em que Freud relata o terror do pequeno menino diante da percepção da falta do falo materno, experimentando uma intensa angústia - a angústia de castração - por saber da possibilidade de sua própria castração. Freud afirma que o fetiche será um substituto do falo materno que a criança "outrora acreditou e que [...] não deseja abandonar" (FREUD, 1927, p. 180). A crença da criança no primado fálico se alteraria após essa percepção e sobre isso Freud diz que a criança "[r]eteve essa crença, mas também a abandonou. No conflito entre o peso da percepção desagradável e a força de seu contradesejo, chegou-se a um compromisso, tal como só é possível sob o domínio das leis inconscientes do pensamento - os processos primários" (p. 181). O compromisso, portanto, reúne realidade e desejo. Essa solução astuta para tentar evitar o temor da castração, em que "permanece um indício do triunfo sobre a ameaça de castração e uma proteção contra ela" (p. 181), se dá devido a uma divisão do eu. A proteção contra a ameaça de castração a que Freud se refere se encarna em algum objeto fetiche, o qual servirá de esteio do desejo fetichista do sujeito, condensando um certo saber sobre a castração da mulher e, ao mesmo tempo, a crença no primado fálico. Conforme Freud nos diz, "tanto a rejeição quando a afirmação da castração encontram caminho na construção do próprio fetiche" (p. 184).

Notemos que tanto o fetichismo marxiano quanto o freudiano ocultam algo, seja a rede de relações sociais, seja a diferença sexual. O fetichismo viria, portanto, (en)cobrir a falta. Vimos com Marx, no capítulo anterior, que as trocas sociais foram 
historicamente deixando de ser um evento ocasional e ampliando-se, e a expressão marxiana da forma de valor desdobrada expressava justamente esse momento lógico-histórico, em que um determinado produto do trabalho passou a ser trocado habitualmente por inúmeras outras mercadorias. Vejamos novamente essa forma:

$\mathrm{z}$ mercadoria $\mathrm{A}=\mathrm{u}$ mercadoria $\mathrm{B}$ ou $=\mathrm{v}$ mercadoria $\mathrm{C}$ ou $=\mathrm{w}$ mercadoria $\mathrm{D}$ ou $=\mathrm{x}$ mercadoria $\mathrm{E}$ ou $=$ etc.

(20 varas de linho $=1$ casaco ou $=10$ libras de chá ou $=40$ libras de café ou $=1$ quarter de trigo ou $=2$ onças de ouro ou $=1 / 2$ tonelada de ferro ou $=$ etc.)

Com a forma desdobrada de valor, Marx nos apresentou o "mundo das mercadorias" (MARX, 1867, p.64), no qual qualquer corpo de mercadoria expressava especularmente o valor de uma determinada mercadoria; por exemplo, o linho, o qual passou a se relacionar com todo o mundo das mercadorias, não mais apenas com uma única mercadoria, como na forma simples de valor. Conforme vimos também, nessa série interminável do mundo das mercadorias, estas ocupavam a posição de equivalentes e serviam como corpo de valor do linho. Porém, Marx nos apontou a incompletude dessa forma devido à série interminável de representações da expressão relativa de valor da mercadoria. $O$ desdobramento seria interminável, portanto, haveria sempre uma nova mercadoria a oferecer-se como material para uma nova expressão de valor. Daí a frase de Marx, a qual citamos anteriormente: "As insuficiências da forma relativa de valor desdobrada refletem-se na sua forma equivalente correspondente" (MARX,1867, p. 65).

Pois bem, se deslizarmos pelo mundo das mercadorias, haverá sempre alguma mercadoria que, por algum momento, ocupará o lugar da falta: o real da mercadoria, o simbólico do lugar (da falta) e o imaginário de seu valor subjetivo. Haverá sempre uma mercadoria disposta a se oferecer ao sujeito como objeto do desejo e que supostamente atenderia de maneira totalmente adequada a demanda do sujeito, suturando a falta. Afinal, a mãe tem falo ou não? A ideologia tem tudo a ver com esse fechamento, ou com esse miraculoso encontro com o falo da mãe. $A$ operação de separação seria, portanto, uma separação desse fechamento da alienação, digamos que seria um momento, ainda que fugaz, de abertura. Seria também uma separação - ainda que fugaz - da ideologia. Nesse sentido, seria um lugar especialmente privilegiado de crítica à ideologia. 


\section{CONSIDERAÇÕES FINAIS}

O que se deseja? Não é o sapatinho, nem o seio, nem seja o que for em que vocês encarnem o fetiche [...] $\mathrm{O}$ desejo, por sua vez, agarra-se onde puder.

Jacques Lacan, O seminário, Livro 10, "A angústia"

Iniciamos a nossa pesquisa com uma apresentação da primeira parte d'A ideologia alemã para mostrar que é, especificamente, nesse texto em que se localiza a concepção marxista de ideologia que o filósofo Slavoj Žižek critica, embora esse autor a localize equivocadamente n'O capital com o fetichismo da mercadoria.

Marx e Engels, no contexto da crítica das representações religiosas de $A$ ideologia alemã, definem a ideologia como um processo restrito à ordem da consciência. A inversão das representações nos indivíduos é uma expressão consciente do modo limitado de sua atividade material e de suas relações sociais. Ou seja, é uma expressão consciente do seu modo de desconhecer a verdadeira realidade. Vejamos essas considerações numa nota de Marx e Engels, na qual eles explicitam a restrição dessa concepção de ideologia à dimensão da consciência:

\footnotetext{
Se a expressão consciente das relações efetivas desses indivíduos é ilusória, se em suas representações põem a sua realidade de cabeça para baixo, isto é consequência de seu modo limitado de atividade material e das suas relações sociais limitadas que daí derivam. (MARX; ENGELS, 1845/1846, p. 93, nota c)
}

Mostramos como essa noção de ideologia, a qual Marx e Engels também nomeiam de "alienação" se estrutura na forma psicanalítica de um sintoma, em sua dimensão simbólica, na medida em que, conforme vimos com Freud, em suas "Conferências introdutórias sobre a psicanálise" (1916/1917), o sintoma também constitui uma expressão do desconhecimento pelo sujeito que dele sofre e se queixa. Em termos lacanianos, vimos como o sintoma constitui uma alienação significante ao campo do Outro. Portanto, o sujeito poderia desalienar-se de seu sintoma a partir de sua interpretação pelo Outro, a quem essa mensagem cifrada estaria endereçada e quem supostamente saberia o seu sentido e dissolvê-lo-ia ao torná-lo consciente para o sujeito que o ignora. O sujeito poderia, então, integrar em sua cadeia simbólica o sentido de seu sintoma que antes Ihe era estranho, alheio. 
Da mesma forma, o sujeito poderia passar da alienação à desalienação de sua consciência, ao conhecer as condições efetivas de sua verdadeira realidade social.

Já em O capital, no contexto da crítica marxiana da economia política, mostramos que a concepção da alienação do fetichismo da mercadoria abarca uma noção mais complexa que remete à ordem do inconsciente. Por meio das transformações que as formas econômicas sofrem ao longo de um processo lógicohistórico que culmina, no capitalismo, com a forma mercadoria, Marx nos mostra como essa forma, ao apagar os rastros de seu desenvolvimento, passa a adquirir poderes mágicos e enigmáticos sobre os sujeitos, revelando a sua determinação de fetichismo.

Tentamos mostrar a presença da fantasia tão logo os produtos são produzidos como mercadorias e também como, sob o fetichismo da mercadoria, o objeto fetiche se torna um objeto fantasiado pelos sujeitos, tanto por seu caráter abstrato e valioso quanto por capturar o desejo em sua forma mercadoria, em suas determinações de valor de troca e valor.

Em seguida, ousamos elaborar uma pequena construção teórica com o objetivo de mostrar as determinações recíprocas existentes entre as operações lacanianas de alienação e separação e o fetichismo da mercadoria. A operação psíquica da alienação promoveria um fechamento imaginário, o qual Marx expressou com a sua forma simples de valor, ao mostrar que uma mercadoria apenas pode expressar o seu valor, portanto advir como mercadoria, pelo corpo de outra mercadoria, em que seu valor se encarne e possa se espelhar. O mesmo acontece com os seres humanos que apenas se reconhecem em sua própria identidade quando um oferece ao outro a imagem espelhada de sua unidade. Conforme vimos em Lacan, o ser vivo apenas advém como sujeito ao alienar-se ao campo simbólico do Outro que lhe antecede.

Apresentamos em Marx como a forma de valor desdobrada expressa um momento lógico-histórico de ampliação das trocas mercantis, quando um produto do trabalho passou a ser trocado não apenas por uma única mercadoria, como na troca simples, mas por todo o "mundo das mercadorias". A forma desdobrada de valor também nos mostrou a série interminável de mercadorias prontas para preencherem o lugar da falta no sujeito. Por isso apontamos a operação psíquica da separação como um lugar de onde se poderia partir para fazer frente à ideologia, já que 
produziria justamente a possibilidade de uma separação do fechamento imaginário da falta no sujeito, fechamento esse operado pela alienação.

Os objetos empíricos do mundo, sob o fetichismo da mercadoria, ao serem oferecidos aos sujeitos como objetos do desejo, supostamente atenderiam a sua demanda e preencheriam a sua falta constitutiva. Em contraposição à noção de um suposto objeto do desejo, buscamos a noção lacaniana de objeto causa do desejo, denominado de objeto a, o qual abordamos pela via da operação lacaniana da separação em sua oposição à alienação. Conforme vimos no livro 11 d'O seminário de Lacan, o objeto a nasce como efeito da lacuna entre o sujeito e o Outro, produzida pela separação. Essa lacuna, como vimos com Soler, onde entra o objeto a, abre uma margem, nas palavras de Žižek, para uma "autonomia subjetiva", que possibilitaria ao sujeito suspender, em certa medida, o efeito de alienação ao Outro. Nos termos de Soler, essa lacuna abre para uma "vontade de sair", um "querer", uma "ação", por parte do sujeito. Entretanto, lembramos aqui a ênfase que demos, no capítulo 4, para a importância de não restringir essa "ação" à ordem da consciência, de forma que recairíamos no sujeito da consciência e da representação. Trata-se de uma ação determinada pelo inconsciente, mas que não deixa de abrir margem para uma possibilidade de ação.

Žižek, ao discorrer sobre a travessia da fantasia social e a identificação com o sinthoma, nos direciona, no campo sócio-político, para esse vazio, para os efeitos, digamos, do real na realidade social. Vimos a sutura que a fantasia ideológica tenta operar nesse furo, mas também a abertura para a ação que a separação possibilita. É nesse contexto que o filósofo esloveno nos deixa uma pista interessante, em seu livro El espinoso sujeto, ao trazer à tona a noção lacaniana de ato como "categoria puramente negativa" (ŽlŽEK, 1999, p. 174). E em uma nota, diz o filósofo: "Esta é a tarefa da atual crítica da ideologia: sacar a luz, mais além de qualquer aparência de ordem ontológica reificada, seu fundamento político renegado: o modo em que gira em torno a algum ato subjetivo excessivo" (p. 171, nota 23$)^{44}$

Para finalizar essas últimas considerações, formulamos a seguinte questão, a qual consideramos que valeria a pena ser investigada: de que modo a psicanálise e

\footnotetext{
${ }^{44}$ Tradução nossa para: "Esta es la tarea de la actual crítica de la ideología: sacar a luz, más allá de cualquier apariencia de orden ontológico reificado, su fundamento político renegado: el modo em que gira em torno a algún acto subjetivo excesivo".
} 
o pensamento marxiano poderiam contribuir para pensarmos o registro dessa "ação" ou desse "ato" negativos, sem uma prescrição positiva da ação ou um procedimento positivo de verdade, pelos sujeitos, sob o capitalismo, para fazer frente à ideologia? Não com o intuito de preencher o vazio, o furo subjetivo/social constitutivo, o que seria ideológico, mas de poder, ao menos, tentar incluí-lo nessa crítica e também nesse ato, sem com isso se pretender afirmar que, dessa forma, se estaria completamente fora da ideologia. 


\section{REFERÊNCIAS BIBLIOGRÁFICAS}

DUNKER, C.I.L. O cálculo neurótico do gozo. São Paulo: Escuta, 2002.

FREUD, S. (1897a). "Carta 66". Em: Obras psicológicas completas de Sigmund Freud, v. I. Rio de Janeiro: Imago, 1996.

(1897b). "Carta 69". Em:

Obras psicológicas completas de Sigmund Freud, v. I. Rio de Janeiro: Imago, 1996.

. (1899). Lembranças encobridoras. Em: Obras psicológicas completas de Sigmund Freud, v. III. Rio de Janeiro: Imago, 1974.

. (1907). "Escritores criativos e devaneio". Em: Obras psicológicas completas de Sigmund Freud, v. IX. Rio de Janeiro: Imago, 1974.

. (1908a). "Algumas observações gerais sobre ataques histéricos". Em: Obras psicológicas completas de Sigmund Freud, v. IX. Rio de Janeiro: Imago, 1976.

. (1908b). "Fantasias histéricas e sua relação com a bissexualidade". Em: Obras psicológicas completas de Sigmund Freud, v. IX. Rio de Janeiro: Imago, 1976.

. (1915a). "O inconsciente". Em:

Introdução ao narcisismo: ensaios de metapsicologia e outros textos (1914/1916). Tradução e notas de Paulo César de Souza. São Paulo: Companhia das Letras, 2010.

. (1915b). "O recalque". Em:

Escritos sobre a psicologia do inconsciente, v. 1. Tradução de Luiz Alberto Hanns. Rio de Janeiro: Imago, 2004.

. (1916/1917a). "Conferência XVI: Psicanálise e psiquiatria". Em:

Obras psicológicas completas de Sigmund Freud, v. XVI. Rio de Janeiro: Imago, 1996.

. (1916/1917b). "Conferência XVII: O sentido dos sintomas". Em:

Obras psicológicas completas de Sigmund Freud, v. XVI. Rio de Janeiro: Imago, 1996.

. (1916/1917c). "Conferência XXIII: Os caminhos da formação dos sintomas".

Em: . Obras psicológicas completas de Sigmund Freud, v. XVI. Rio de Janeiro: Imago, 1996.

. (1916/1917d). "Conferência XXVII: Transferência". Em:

Obras psicológicas completas de Sigmund Freud, v. XVI. Rio de Janeiro: Imago, 1996.

. (1927). "Fetichismo". Em: Obras psicológicas completas de Sigmund Freud: Edição Standard Brasileira. Volume XXI. Rio de Janeiro: Imago, 1976. 
GARCIA-ROZA, L. A. "Recalcamento". Em: Introdução à metapsicologia freudiana, v. 3. 4. ed. Rio de Janeiro: Jorge Zahar Editor, 2000.

LACAN, J. (1964). "O sujeito e o Outro (I): a alienação" (1964). Em: 0 seminário, livro 11: os quatro conceitos fundamentais da psicanálise. Rio de Janeiro: Zahar, 2008.

. (1960/1964) "Posição do inconsciente no Congresso de Bonneval". Em: . Escritos. Rio de Janeiro: Zahar, 1998.

LAPLANCHE, J.; PONTALIS, J.-B. (1964). Fantasia originária, fantasias das origens, origens da fantasia. Rio de Janeiro: Jorge Zahar Editor, 1988.

LAURENT, E. "Alienação e separação I". Em: FELDSTEIN, R.; FINK, B.; JAANUS, M. (orgs.). Para ler o Seminário 11 de Lacan. Rio de Janeiro: Zahar, 1997a.

. "Alienação e separação II". Em: FELDSTEIN, R.; FINK, B.; JAANUS, M. (orgs.). Para ler o Seminário 11 de Lacan. Rio de Janeiro: Zahar, 1997b.

LUKÁCS, G. El jovem Hegel y los problemas de la sociedad capitalista. México, D. F.: Editorial Grijalbo S. A., 1963.

MARX, K. (1845). Teses sobre Feuerbach. Em: MARX, K.; ENGELS, F. (1845/1846). A ideologia alemã. São Paulo: Boitempo Editorial, 2007.

. (1859). Contribuição à crítica da economia política. 2. ed. São Paulo: Expressão Popular, 2007.

. (1867). O capital. 3. ed. São Paulo: Nova Cultural, 1988 (Coleção Os Economistas).

MARX, K; ENGELS, F. (1845/1846). A ideologia alemã. São Paulo: Boitempo Editorial, 2007.

MILLER, J.-A. (1983). "Duas dimensões clínicas: sintoma e fantasia". Em:

Percurso de Lacan: uma introdução. Rio de Janeiro: Jorge Zahar Editor, 1987.

OCARIZ, M. C. O sintoma e a clínica psicanalítica: o curável e o que não tem cura. São Paulo: Via Lettera Editora e Livraria, 2003.

SAFATLE, V. "Posfácio: a política do Real de Slavoj Žižek". Em: ŽlŽEK, S. Bemvindo ao deserto do real! São Paulo: Boitempo, 2003.

SILVEIRA, P. "Da alienação ao fetichismo - formas de subjetivação e de objetivação". Em: SILVEIRA, P.; DORAY, B. (orgs.). Elementos para uma teoria marxista da subjetividade. São Paulo: Vértice/Editora Revista dos Tribunais, 1989, p. 41-76 (Enciclopédia Aberta da Psique).

SOLER, C. "O sujeito e o Outro I". Em: FELDSTEIN, R.; FINK, B.; JAANUS, M. (orgs.). Para ler o Seminário 11 de Lacan. Rio de Janeiro: Zahar, 1997a. 
. "O sujeito e o Outro II". Em: FELDSTEIN, R.; FINK, B.; JAANUS, M. (Orgs). Para ler o Seminário 11 de Lacan. Rio de Janeiro: Zahar, 1997b.

TEISSIER, M.-J. (1994). "Alienação-separação". Em: CHEMAMA, R. et al. Dicionário de Psicanálise - Freud \& Lacan, v. 2. $2^{a}$ edição. Salvador: Ágalma, 2004.

ŽlŽEK, S. Eles não sabem o que fazem: o sublime objeto da ideologia. Rio de Janeiro: Jorge Zahar Editor, 1992.

. (1999). El espinoso sujeto: el centro ausente de la ontologia política. Buenos Aires: Paidós, 2007.

. "Un alegato por la violência ética". En: ŽIŽEK, S.; HOUNIE, A. (orgs.). Violencia en acto: conferências em Buenos Aires. 1. ed. Buenos Aires: Paidós, 2005.

. 'Como Marx inventou o sintoma?'. Em:

S. (org.). Um mapa da ideologia. Rio de Janeiro: Contraponto, 2007 a. . 'O espectro da ideologia'. Em: de Janeiro: Contraponto, 2007b. (org.). Um mapa da ideologia. Rio 